\author{
UNIVERSIDADE DE SÃO PAULO \\ ESCOLA DE ARTES, CIÊNCIAS E HUMANIDADES \\ PROGRAMA DE PÓS-GRADUAÇÃO EM SUSTENTABILIDADE
}

CELLY KELLY NEIVAS DOS SANTOS

\title{
Governança Colaborativa na Educação Ambiental: a implementação da política de educação ambiental no município de Suzano
}

Versão Original 


\title{
Governança Colaborativa na Educação Ambiental: a
} implementação da política de educação ambiental no município de Suzano

\author{
Versão Original \\ Dissertação apresentada à Escola de Artes, \\ Ciências e Humanidades da Universidade de \\ São Paulo para obtenção do título de Mestre \\ em Ciências pelo Programa de Pós- \\ graduação em Sustentabilidade.
}

Orientador: Prof. Dr. Cristiano Luis Lenzi

Linha de Pesquisa: Gestão Ambiental

São Paulo 
Autorizo a reprodução e divulgação total ou parcial deste trabalho, por qualquer meio convencional ou eletrônico, para fins de estudo e pesquisa, desde que citada a fonte.

CATALOGAÇÃO-NA-PUBLICAÇÃO

(Universidade de São Paulo. Escola de Artes, Ciências e Humanidades. Biblioteca)

Santos, Celly Kelly Neivas dos

Governança colaborativa na educação ambiental : a implementação da política de educação ambiental no município de Suzano / Celly Kelly Neivas dos Santos ; orientador, Cristiano Luis Lenzi. - São Paulo, 2015 $100 \mathrm{f}$. : il

Dissertação (Mestrado em Ciências) - Programa de PósGraduação em Sustentabilidade, Escola de Artes, Ciências e Humanidades, Universidade de São Paulo Versão original

1. Educação ambiental - Suzano (SP). 2. Políticas públicas - Suzano (SP). 3. Participação política. I. Lenzi, Cristiano Luis, orient. II. Título

CDD 22.ed. - 577.07098161 
Dissertação de autoria de SANTOS, C. K. N. dos, sob o título "Governança Colaborativa na Educação Ambiental: a implementação da política de educação ambiental no município de Suzano", apresentada à Escola de Artes, Ciências e Humanidades da Universidade de São Paulo, para obtenção do título de Mestre em Ciências pelo Programa de Pós-graduação em Sustentabilidade, na área de concentração Gestão Ambiental, aprovada em _ de de ___ pela comissão julgadora constituída pelos doutores:

Prof. Dr.

Presidente

Instituição:

Prof. Dr.

Instituição:

Prof. Dr.

Instituição: 
Para Geraldo e Luiza, in memoriam. 


\section{Agradecimentos}

A Deus, pela vida e por tudo o que nela há.

À minha família pelo grande incentivo, colaboração e amor vindo de minha mãe Luzia, minha irmã Cintia e meu filho João Pedro. Estendo minha gratidão às minhas primas queridas Lygia, Thalita e Thamires, ao Gabriel, aos meus tios João e Ana e aos agregados queridos Douglas Assis e Janne Loponen. Agradeço ao Sr. Djalma e D. Herondina pelo apoio constante.

Ao professor Cristiano Lenzi pela orientação deste trabalho, principalmente por apresentar uma nova lente de visão sobre a Educação Ambiental, e pela paciência.

À Silvia Stuchi, amiga querida e primeira incentivadora desta jornada.

Ao abrigo de corpo e alma dado por Heloísa Mota, Oscar Chagas, Capitu, Priscila Rosa, Maíra Padgurschi e Guilherme Gorgulho.

À Thelma Palmeira pelo incondicional apoio em todos os momentos.

Ao Luiz Nepomuceno, companheiro e grande apoiador, ainda que sem muito jeito.

À Maria Henriqueta, amiga de jornada e referência de vida.

Aos demais amigos que contribuíram com este trabalho, Nadja Soares, Fabio Ferreira, Jefferson Correia, Maíra Simões, Luciana Ferreira e Admilson Barbosa.

Agradeço a todos os participantes da CIMEA-Suzano, em especial à Aline Guarizo pela amizade consolidada.

À Diretoria pelo conforto da amizade. 


\section{RESUMO}

SANTOS, C. K. N. Governança Colaborativa na Educação Ambiental: a implementação da política de educação ambiental no município de Suzano. 2015. 100 fls. Dissertação (Mestrado) - Escola de Artes, Ciências e Humanidades, Universidade de São Paulo, São Paulo, 2015.

O Programa Nacional de Educação Ambiental (ProNEA) baseado na Política Nacional de Educação Ambiental (PNEA) estimula estados e municípios a desenvolverem suas políticas de Educação Ambiental (EA) com a formação de Comissões de Educação Ambiental. O intuito desta estratégia é promover nos territórios o diálogo entre os diversos setores da sociedade para efetivar a implantação das políticas pública de EA, considerando a EA como atividade fundamental de formação de pessoas para o exercício da cidadania responsável e consciente, capazes de construírem e prosperarem sociedades sustentáveis. Imbuído deste desafio o município de Suzano, SP, criou em 2011 sua Comissão Interinstitucional Municipal de Educação Ambiental (CIMEA-Suzano), responsável pela Política e pelo Sistema de Educação Ambiental do município. A CIMEA-Suzano é considerada referência de política de EA no Brasil, inspirando a criação de outras comissões em diversos municípios brasileiros. Seu processo de desenvolvimento está alicerçado no ProNEA e seu modelo de atuação configura um arranjo colaborativo ao integrar atores públicos, privados e pessoas no provimento de políticas públicas de EA. O presente trabalho buscou interpretar a CIMEASuzano sob a perspectiva da governança colaborativa com o objetivo de reconhecer nos seus processos de implementação e atuação, os mecanismos de colaboração que a permitiram alcançar as diretrizes e os princípios postulados pelo ProNEA. O desenvolvimento desta pesquisa se baseia no aprofundamento dos temas da Governança e da Educação Ambiental enquanto política pública, para identificar e contextualizar o regime de governança colaborativa nos processos de implementação e atuação da CIMEA-Suzano. A metodologia de trabalho baseia-se numa análise de conteúdo do período 2009 - 2012 e inclui entrevistas abertas com pessoas chaves integrantes da CIMEA-Suzano.

Palavras-chave: educação ambiental; política pública; governança colaborativa. 


\begin{abstract}
SANTOS, C. K. N. Collaborative Governance in Environmental Education: the environmental education policy implementation in the city of Suzano. 2015. 100 p. Dissertation (Master of Science) - School of Arts, Science and Humanities, University of São Paulo, São Paulo, 2015.

The Environmental Education National Program (ProNEA) based on National Policy of Environmental Education (PNEA) stimulates estates and municipalities to develop environmental education policies through formation of Environmental Education's Commission. The aim of this strategy is to promote on the territories the dialogue among different social sectors to effect the environment education public policies, considering the environmental education (EE) as the fundamental activity to form people to the citizenship responsibly and conscious, able to build and thrive sustainable society. With this challenge the municipality of Suzano creates in 2011 its Inter-institutional Municipal of Environmental Education Commission (CIMEA), responsibly for the Municipal Policy and System of Environmental Education of the city. The CIMEA is considered reference of EE policy in Brazil, inspiring the creation of others commissions in many Brazilian cities. Its development process is sustained on ProNEA and its action model comprehends a collaborative design that integrates people, public and private actors on the EE public policy development. This work sought to interpret the CIMEA as a collaborative governance regime and the goal was recognize in its actions and implementation process the collaborative mechanisms that allowed reach the ProNEA principles and guidelines. This research development is based on deepen study of Collaborative Governance theme and Environmental Education Policy to identify and contextualize the Collaborative Governance Regime on the actions and implementation process of CIMEA. The methodology is based on a content analysis of the period 2009 - 2012 and includes open interviews with key personnel members of CIMEA.
\end{abstract}

Keywords: environmental education; public policy; collaborative governance 


\section{Lista de figuras}

Figura 1 - Quadro Integrativo para Governança Colaborativa ............................................. 31

Figura 2 - Modelo Colaborativo para Planejamento Ambiental ........................................... 31

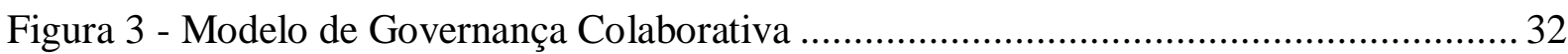

Figura 4 - Fases do Processo Colaborativo em Selin e Chavez (1995) ................................ 35

Figura 5 - Eixos estruturantes da PMEA e SISMEA de Suzano ........................................ 47

Figura 6 - Reportagem sobre a formação da CIMEA-Suzano ............................................ 50

Figura 7 - Reportagem sobre a adesão de 50 pessoas a CIMEA-Suzano …........................... 51

Figura 8 - Projeto Político Pedagógico da CIMEA-Suzano.............................................. 52

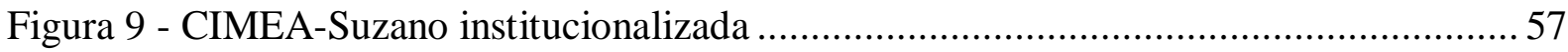

Figura 10 - Convite mesa-redonda aberto à população...................................................... 58

Figura 11 - Boletim da CIMEA convidando para a discussão da lei de EA .......................... 58 


\section{Lista de tabelas}

Tabela 1 - Diretrizes e Princípios do ProNEA …............................................................... 21

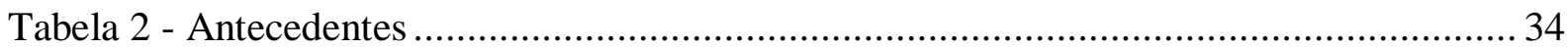

Tabela 3 - Matriz do Processo Colaborativo ........................................................................ 39

Tabela 4 - Pressupostos teóricos dos temas interseccionais ................................................ 41 


\section{Sumário}

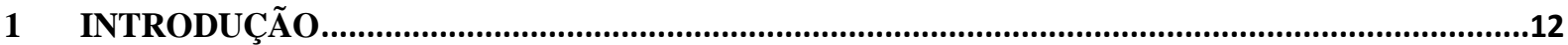

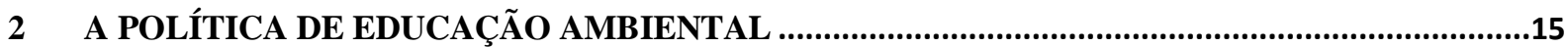

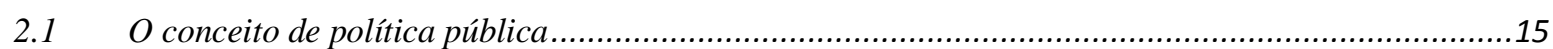

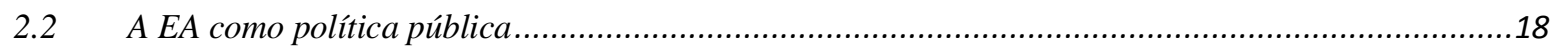

2.3 A Política e o Programa Nacional de Educação Ambiental...........................................................20

2.4 Breve apresentação da Comissão Interinstitucional Municipal de Educação Ambiental de Suzano...22

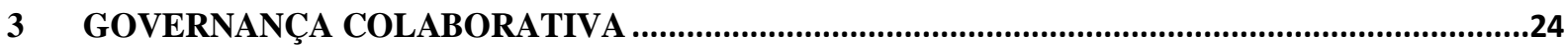

3.1 Origem e conceito do termo Governança Colaborativa ............................................................25

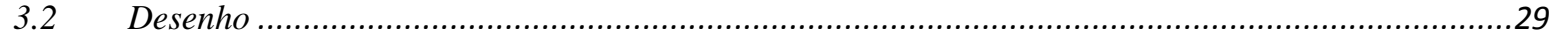

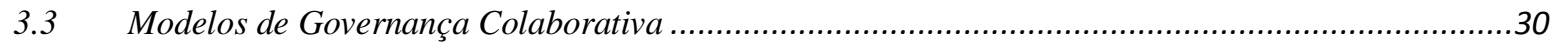

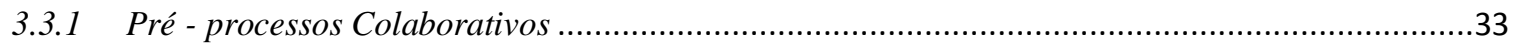

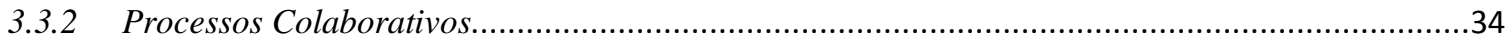

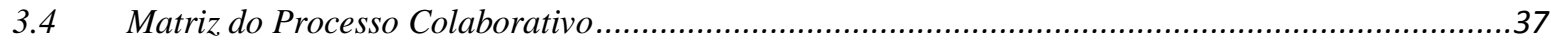

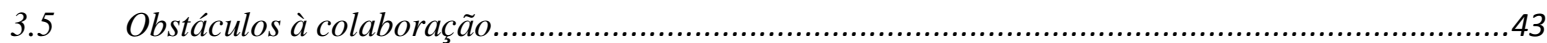

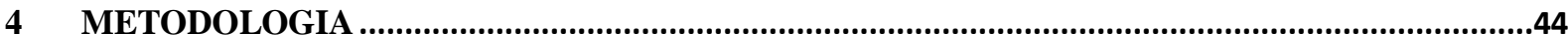

4.1 Procedimentos de coleta de dados........................................................................................44

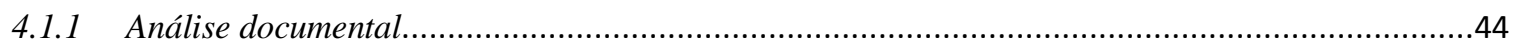

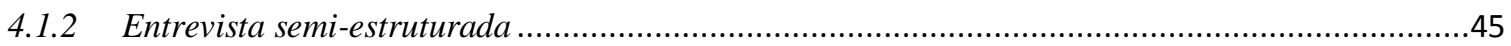

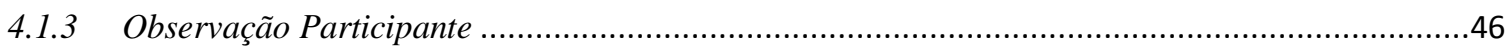

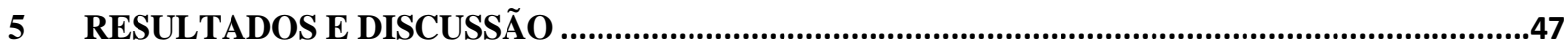

5.1 O pré-processo colaborativo da CIMEA-Suzano........................................................................47

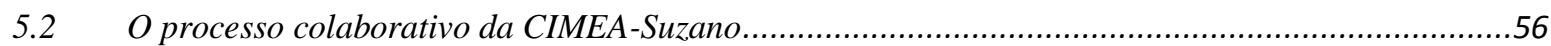

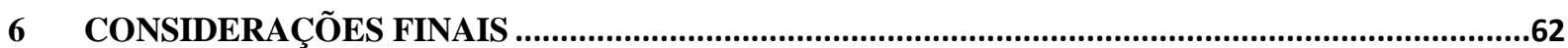

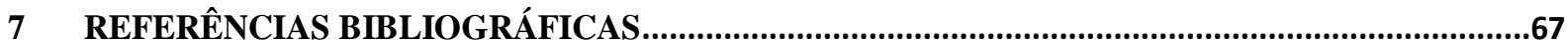

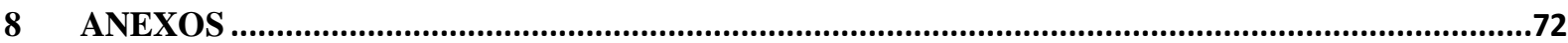




\section{INTRODUÇÃO}

No Brasil a Educação Ambiental (EA) é uma prática regulamentada por legislação própria e amparada na Constituição Federal de 1988, precisamente no inciso VI, § $1^{\circ}$ do artigo 225 que assegura a efetividade do direito ao meio ambiente através da promoção "da educação ambiental em todos os níveis de ensino e a conscientização pública para a preservação do meio ambiente".

O Programa Nacional de Educação Ambiental (ProNEA) é o instrumento da Política Nacional de Educação Ambiental (PNEA) ${ }^{1}$ que apresenta as diretrizes, a missão e as linhas de atuação e estratégia em que a prática da EA deve ocorrer no país. Apesar de se constituir em um programa governamental, sua execução não é de competência exclusiva do poder público federal, mas sim, "todos os segmentos sociais e esferas de governo são corresponsáveis pela sua aplicação, execução, monitoramento e avaliação” (BRASIL, 2005, p. 15).

A PNEA teve sua regulamentação através do decreto 4.281/02 o que possibilitou em 2003 a constituição do Órgão Gestor (OG) previsto no artigo 14 da Lei 9.795/99, cuja responsabilidade é implementar os programas e projetos desenhados no âmbito do ProNEA (BRASIL, 2006; LUCA, 2013).

O Órgão Gestor da PNEA é dirigido pelos ministros de meio ambiente e educação, sendo assessorado por um comitê composto por treze representações da sociedade civil e de instituições federais, estaduais e municipais (BRASIL, 2005). O Comitê Assessor tem a função de "assessorar o Órgão Gestor no planejamento e avaliação de diretrizes e ações relativas ao processo de implementação da PNEA" constituindo-se em uma "instância de controle social dessa política pública, e uma das vias para o enraizamento da educação ambiental no Brasil”, (BRASIL, 2006, p.11).

Dentre as estratégias definidas pelo ProNEA destaca-se o incentivo à criação e fortalecimento das Comissões Estaduais Interinstitucionais de Educação Ambiental (CIEAs), as quais, espelhadas no OG da PNEA, devem formular seus próprios órgãos gestores estaduais e seus comitês assessores. Para o OG da PNEA, as CIEAs "têm como missão mais ampla propor as diretrizes da Política e do Programa Estadual de Educação Ambiental,

\footnotetext{
${ }^{1}$ Lei 9.795/99.
} 
coordenando e interligando as atividades relacionadas à educação ambiental” (BRASIL, 2005, p. 07).

Os municípios são encorajados pelo ProNEA a formularem suas comissões municipais a exemplo dos estados, pautados pela PNEA e pelo Tratado Internacional de Educação Ambiental para Sociedades Sustentáveis e Responsabilidade Global. Imbuído deste desafio, o município de Suzano (SP) criou sua Comissão Interinstitucional Municipal de Educação Ambiental (CIMEA), de onde partiram a estruturação do Sistema Municipal de Educação Ambiental (SISMEA) e a Política Municipal de Educação Ambiental (PMEA).

De acordo com a Prefeitura Municipal de Suzano (2012, p. 16) a CIMEA-Suzano é um "colegiado gestor deliberativo, formado por segmentos da sociedade civil, setor privado e poder público com atuação no município de Suzano e região". Caracteriza-se como um "fórum permanente de diálogos, reflexões, construções, produções e tomadas de decisão sobre a busca da qualidade de vida, justiça socioambiental e proteção do meio ambiente" além de “contribuir na construção, [...] participar, apoiar, acompanhar e avaliar a política, o sistema e o programa de educação ambiental do município".

A CIMEA-Suzano assemelha-se a um tipo de gestão pública inovadora no que se refere à participação da sociedade civil. Mostra-se como um processo de governança que estimula a formulação e a implementação das políticas de forma não restrita às agências públicas, mas através de um crescente número de relacionamentos entre organizações públicas e não públicas (AGRANOFF e McGUIRE², 2003 apud LIMA, 2007).

Tendo a CIMEA-Suzano uma configuração com a qual se pode reconhecer um modelo de governança colaborativa, este projeto de pesquisa se volta a uma análise históricodescritiva de sua formação e atuação, identificando os processos de tomada de decisão, formulação da PMEA e do SISMEA através da ação conjunta e organizada entre entes públicos, privados e civis.

Para tanto, a primeira parte desta pesquisa se debruçará sobre uma fundamentação teórica acerca da EA enquanto política pública e da Governança Colaborativa enquanto um modelo de gestão pública. A segunda parte tratará de caracterizar uma Matriz de Governança

\footnotetext{
2 AGRANOFF, R.; MCGUIRE, M. Collaborative Public Management: New Strategies for Local Governments. Washington, DC: Georgetown University Press, 2003.
} 
Colaborativa a partir dos modelos de análises propostos por Ansell e Gash (2007), Selin e Chavez (1995); Bentrup (2001) e Emerson, Nabatchi e Balogh (2012). A parte final desta pesquisa se dedica a analisar os componentes e os processos colaborativos da CIMEA-Suzano através da Matriz de Governança Colaborativa.

Esta é uma análise importante para discutir se o processo de construção da política de EA desenvolvida pelo município de Suzano contemplou as diretrizes e os princípios propostos pelo ProNEA, em especial a contemplação das diretrizes de Descentralização Espacial e Institucional e Democracia e Participação Social, além do princípio do Enfoque humanista, histórico, crítico, político, democrático, participativo, inclusivo, dialógico, cooperativo e emancipatório.

Também é relevante para este projeto de pesquisa discutir a importância de modelos colaborativos de gestão pública que possibilitem a orientação de agentes públicos e privados para a reflexão, a construção e a implementação de políticas públicas voltadas à solução de questões estruturais e que almejam a sustentabilidade socioambiental.

Portanto, este projeto de pesquisa parte da hipótese de que a CIMEA-Suzano compreende processos colaborativos em sua formação e atuação, inferindo-se que nela esteja abarcado o ferramental para o alcance das diretrizes e princípios estipulados pelo ProNEA, precisamente os destacados neste texto. Assim como a CIMEA-Suzano se constitui em um regime de governança capaz de colaborar com uma política pública voltada à construção de uma sociedade sustentável. 


\section{A POLÍTICA DE EDUCAÇÃO AMBIENTAL}

O tratamento da EA enquanto política pública passa necessariamente pela análise e entendimento do que cada conceito representa. Desta forma, este primeiro capítulo procurou descrever os conceitos de políticas públicas e de EA separadamente, para assim desvelar, como e por que a Educação Ambiental tornou-se uma política pública no Brasil.

\subsection{O conceito de política pública}

Antes de conceituar o termo política pública é importante lembrar que a literatura estrangeira distingue o tema em três diferentes significados. Segundo Rocher (2002) o significado das palavras polity, politics e policy é diferente e repleto de significados para os cidadãos de língua inglesa. Para nós, cidadãos de língua portuguesa, uma só palavra (política) nos dá, de maneira genérica e principalmente, no entendimento popular, o objetivo e o significado desta mesma variedade de situações e de conteúdo. No entanto, o termo polity denomina as instituições políticas; o termo politics denomina os processos políticos e, por fim, policy denomina os conteúdos da política (FREY, 2000). As políticas públicas estão entendidas dentro do conceito de policy. A clareza sobre estas definições é de suma importância ao investigar na literatura estrangeira os temas desta pesquisa.

A definição de política pública mais conhecida segundo Souza (2006, p. 24) é a de Lasswell $(1936)^{3}$, para quem as políticas públicas seriam o governo em ação e cujas "decisões e análises sobre política pública implicam responder às seguintes questões: quem ganha o quê, por quê e que diferença faz". Lasswell sintetiza nestas questões o jogo político e as relações de poder e de influência das partes envolvidas; lança sobre o conceito o balanço de realizar ou não determinada ação e a iniciativa de mudanças de uma situação dada.

Heidemann (2009, p. 30) nos facilita a compreensão das questões lançadas por Lasswell ao destacar dois elementos-chaves na definição de políticas públicas: a ação e a intenção. Para o autor até "pode haver uma política sem uma intenção formalmente manifestada, mas não haverá de forma alguma uma política positiva se não houver ações que materializam uma intenção ou propósito oficial”, e que, portanto, não há política sem ação. Compreende-se assim, que não realizar uma determinada ação, encerra uma ação política em si. O complemento de Heidemann para o conceito de política compreende "ações, práticas,

\footnotetext{
${ }^{3}$ LASSWELL, H.D. Politics: Who Gets What, When, How. Cleveland, Meridian Books. 1936/1958
} 
diretrizes e políticas fundadas em leis e empreendidas como funções de Estado por um governo, para resolver questões gerais e específicas da sociedade” (p. 29).

Outra importante definição é identificada por Capella (2006) que apresenta o conceito de política pública formulado por Kingdon $(1984,2003)^{4}$, o qual considera as políticas públicas um conjunto formado pelos processos de (1) estabelecimento de uma agenda, (2) de formulação das políticas públicas a partir de escolhas que serão realizadas, (3) da escolha dominante entre o conjunto de alternativas disponíveis e (4) da implementação da decisão. Com isso, Kingdon não apenas apresenta sua definição para política pública, mas esboça um ciclo para ela, cujo ponto de surgimento é a definição da agenda. A agenda, segundo Kingdon, significa um "conjunto de assuntos sobre os quais o governo e pessoas ligadas a ele concentram sua atenção num determinado momento" (p. 26).

As definições do termo política pública de Lasswell e Kingdon são para Amorim e Boullosa (2013, p. 62) classificadas como estatistas, onde “o caráter público é definido pelo tipo de ator que a ativa, ou seja, a política é pública, porque é formulada e implementada pelo governo". Dicotomicamente, as autoras propõem uma segunda compreensão para o termo política pública, destacando-o não como "ações do governo, mas como ações de governo, onde quem governa é quem se atoriza nos processos e nos fluxos em curso de políticas públicas”. Reclassificam assim a política pública como pluralista, onde uma multiplicidade de atores pode assumir o protagonismo nos processos de políticas públicas.

A perspectiva da política pública formulada e implementada também pela sociedade e não como uma ação exclusiva do Estado pelos governos é, possivelmente, a noção de política pública que mais se aproxima da perspectiva de políticas públicas de EA postulada pelo ProNEA.

O ProNEA propõe um constante exercício de transversalidade para internalizar, por meio de espaços de interlocução bilateral e múltipla, a educação ambiental no conjunto do governo, nas entidades privadas e no terceiro setor; enfim, na sociedade como um todo. Estimula o diálogo interdisciplinar entre as políticas setoriais e a participação qualificada nas decisões sobre investimentos, monitoramento e avaliação do impacto de tais políticas (BRASIL, 2014, p. 23)

Para além da metodologia dialógica com que as políticas de EA materializam a transversalidade, ponto este a ser discutido com maior profundidade no capítulo de análise dos resultados desta pesquisa, e retornando a atenção aos conceitos de políticas públicas,

\footnotetext{
${ }^{4}$ KINGDON, J. Agendas, Alternatives, and public policies. 3 ed. Nova York: Harper Collins, 1984/2003.
} 
Sorrentino (2005, p.286) apresenta sua definição para o termo incluindo a dimensão da sustentabilidade e da cidadania, assim como assinala as múltiplas origens e atores para as demandas a serem debatidas.

\begin{abstract}
Considerando a ética da sustentabilidade e os pressupostos da cidadania, a política pública pode ser entendida como um conjunto de procedimentos formais e informais que expressam a relação de poder e se destina à resolução pacífica de conflitos assim como à construção e aprimoramento do bem comum. Sua origem está nas demandas provenientes de diversos sistemas (mundial, nacional, estadual, municipal) e seus subsistemas políticos, sociais e econômicos, onde as questões que afetam a sociedade se tornam públicas e formam correntes de opinião com pautas a serem debatidas em fóruns específicos.
\end{abstract}

Das questões que afetam a sociedade, os riscos ambientais e os agravos sociais deles decorrentes, passaram a ocupar cada vez mais as agendas governamentais. De certo, tais questões já ocupam a agenda da sociedade e são discutidas e muitas vezes combatidas em iniciativas individuais, principalmente pelas organizações não governamentais (ONGs), entre elas empresas e instituições sem fins lucrativos. Trata-se de uma agenda socioambiental, postulada pela sociedade e desenvolvida por aqueles que, ao colaborarem com o bem comum, compartilham o espaço das políticas públicas com o Estado.

Contudo, ainda que "a construção do bem comum pode se dar por iniciativas privadas, só aquelas assimiladas pelo Estado atingem uma condição de legitimidade (obrigatoriedade legal), universalidade (alcance de todos os cidadãos) e capacidade coercitiva (punição aos violadores) perante a sociedade", conforme Andrade e Sorrentino (2013, p. 217) destacam em Dye $(2009)^{5}$.

Desta afirmativa, paira a necessidade de, por um lado sensibilizar o Estado para receber e desenvolver esta agenda socioambiental, e por outro lado, promover na sociedade as habilidades necessárias para incuti-la no Estado. A fé no cumprimento deste papel está depositada nas políticas públicas de EA, pois são estas que levam as demandas socioambientais à tona das discussões para ganharem aderência nas práticas educativas e formativas, elevando-as às instâncias de decisão, neste caso, instâncias públicas para se transformarem em processos regulamentados.

\footnotetext{
${ }^{5}$ DYE, T. R. Mapeamento dos modelos de análise de políticas públicas. IN: HEIDEMANN, F. G.; SALM, J. F. (Orgs.). Políticas públicas e desenvolvimento: bases epistemológicas e modelos de análise. Brasília: UNB, 2009 p. 99-129.
} 


\title{
2.2 A EA como política pública
}

Ao tratar a EA enquanto política pública há que se trazer para o texto um entendimento do que ela trata, ou não trata, como propõe Sauvè (2005) ao pronunciar que EA não é uma forma de educação entre inúmeras outras; não é simplesmente uma ferramenta para a resolução de problemas ou de gestão do meio ambiente.

Sauvè pretende com esta exposição ampliar a percepção da EA para além da educação formal, entendendo-a como uma "dimensão essencial da educação fundamental que diz respeito a uma esfera de interações que está na base do desenvolvimento pessoal e social: a da relação com o meio em que vivemos, com essa 'casa de vida' compartilhada” (SAUVÉ, 2005, p. 317 - grifo da autora).

O Tratado de Educação Ambiental para Sociedades Sustentáveis e Responsabilidade Global, documento produzido na Jornada Internacional de Educação Ambiental durante o Fórum Global paralelo à Rio-92, traz uma das mais aceitas definições de EA que diz

\begin{abstract}
A educação ambiental consiste em processos permanentes, continuados, articulados e com a totalidade dos habitantes de cada base territorial; de aprendizagem baseada no cuidado e respeito com todas as formas de vida e na conservação, recuperação e melhoria do meio ambiente e da qualidade de vida. Tal educação afirma valores e ações que contribuem para a transformação humana e social e estimula a formação de sociedades sustentáveis, que conservam entre si relação de interdependência e diversidade. Isto requer responsabilidade individual e coletiva em nível local, nacional e planetário.
\end{abstract}

É possível ainda atribuir à EA, segundo Jacobi, Tristão e Franco (2009, p. 67 - grifo dos autores), ser uma "proposta de educação reflexiva e engajada, centrada nos saberes e fazeres construídos com e não para os sujeitos", sendo ainda para Sorrentino e col. (2005), a transformação social que visa à superação das injustiças ambientais, da desigualdade social, da apropriação capitalista e funcionalista da natureza e da própria humanidade.

Um importante marco de discussão sobre EA é a Primeira Conferência Intergovernamental sobre Educação Ambiental ocorrida em Tbilisi, Georgia, no ano de 1977, a qual produziu a Declaração de Tbilisi com os princípios, estratégias e ações orientadoras em EA que são adotados até a atualidade. No Brasil, a trajetória de discussões em torno da EA teve início ainda na década de 1980, em um “momento de 'abertura' política, após o fim do regime militar, com a reconquista dos direitos civis e políticos e o crescimento dos movimentos sociais" (NASCIMENTO, 2010, p. 108 - grifo da autora). Pensadores, universitários, intelectuais, educadores e outros grupos interessados alavancaram uma dezena 
de seminários e encontros para discussão do tema, impulsionados pelos grandes eventos e documentos produzidos nas décadas anteriores.

Em 1988 a Constituição Federal dedicou um capítulo inteiro à questão ambiental, colocando em seu artigo $225, \S 1^{\circ}$, VI

Todos têm direito ao meio ambiente ecologicamente equilibrado, bem de uso comum do povo e essencial à sadia qualidade de vida, impondo-se ao Poder Público e à coletividade o dever de defendê-lo e preservá-lo para as presentes e futuras gerações (BRASIL, 1988).

Nascimento (2010, p. 110) pontua ainda no $\S 1^{\circ}$ que “objetivando assegurar esse direito", incumbe ao Poder Público "promover a educação ambiental em todos os níveis de ensino e a conscientização pública para a preservação do meio ambiente”.

Observada na Constituição Federal, a Educação Ambiental ganhou peso para que fosse levada ao patamar de política nacional, ao lado de outras políticas como a de recursos hídricos e resíduos sólidos. Soma-se a este peso, o aparato institucional e legal que o Estado proporcionou entre as décadas de 1980 e 2000 entre seus ministérios e autarquias, favorecendo a instalação de um instrumento político para ordenação de tal aparato.

"Frequentemente, são a mídia e outras formas da comunicação política e social que contribuem para que seja atribuída relevância política a um problema peculiar" (FREY, 2000, p. 227). Este posicionamento nos permite inferir a pressão exercida pela Eco 92 no governo brasileiro para que se instituísse um aparato legal e institucional mais incisivo sobre as questões ambientais.

A participação do Brasil na Eco 92 se deu através de uma Comissão Interministerial de Meio Ambiente (CIMA) com a participação de 23 órgãos públicos de onde foi criada a Secretaria do Meio Ambiente da Presidência da República, transformando-se apenas em 1994 no Ministério do Meio Ambiente (PECCATIELO, 2011).

O apelo midiático da Eco 92 não pôde deixar de ser considerado. A participação de mais de 150 países neste evento sediado na cidade do Rio Janeiro teve repercussão mundial em jornais e telejornais, os quais discutiam veementemente a posição dos países participantes, e com certeza do país anfitrião. "Questões emergentes na agenda midiática influenciam diretamente a agenda pública, tendo também abrangência sobre a agenda governamental" (CAPELLA, 2006, p. 09). 
Apesar do aparato legal instituído na década de 1990, o empenho do governo em colocar em prática as prerrogativas da lei e de seus instrumentos teve maior ênfase a partir da década de 2000, com as revisitações do Programa Nacional de Educação Ambiental $(\text { PRONEA })^{6}$, dadas através de processos participativos amplos entre as esferas públicas e não públicas, resultando em sua terceira versão, em um documento "orientador de processos de educação ambiental locais" (BRASIL, 2006). Em 2014, o documento sofreu a quarta revisão tornando-se a versão mais atualizada.

Desta forma, o então ProNEA passou a estabelecer um conjunto de programas e projetos junto às "redes públicas de ensino, unidades de conservação, prefeituras municipais, empresas, sindicatos, movimentos sociais, organizações da sociedade civil, consórcios e comitês de bacia hidrográfica, assentamentos de reforma agrária, dentre outros parceiros" (SORRENTINO e col., 2005, p. 290).

A busca pela universalização de atores e extratos sociais na dinâmica de participação de seus programas e projetos dá à PNEA a relevância de uma política pública participativa, o que para um estado democrático, é de fundamental importância. Isto é bastante notório nas linhas de ação e estratégias que empreende, formando uma estrutura capilarizada de atores e instituições em torno da construção de políticas públicas socioambientais em escala nacional e subnacional.

\subsection{A Política e o Programa Nacional de Educação Ambiental}

No Brasil a EA é uma prática regulamentada por legislação própria e amparada na Constituição Federal de 1988, precisamente no inciso VI, $\S 1^{\circ}$ do artigo 225 que assegura a efetividade do direito ao meio ambiente através da promoção "da educação ambiental em todos os níveis de ensino e a conscientização pública para a preservação do meio ambiente”.

O ProNEA enquanto instrumento da PNEA, apresenta as diretrizes, a missão e as linhas de atuação e estratégia em que a prática EA deve ocorrer no país. Constitui-se em um documento de caráter prioritário e permanente, devendo assim ser reconhecido por todos os governos brasileiros.

\footnotetext{
${ }^{6}$ A sigla PRONEA é referente ao programa instituído em 1994, ao passo que a sigla ProNEA refere-se ao Programa instituído em 1999 e revisado em 2014.
} 
Tabela 1 - Diretrizes e Princípios do ProNEA

\begin{tabular}{|c|c|}
\hline Diretrizes & Princípios \\
\hline \multirow{3}{*}{$\begin{array}{l}\text { Transversalidade e } \\
\text { Insterdisciplinaridade; }\end{array}$} & $\begin{array}{l}\text { Concepção de ambiente em sua totalidade, considerando a interdependência } \\
\text { sistêmica entre o meio natural e o construído, o socioeconômico e o cultural, } \\
\text { o físico e o espiritual, sob o enfoque da sustentabilidade; }\end{array}$ \\
\hline & $\begin{array}{l}\text { Abordagem articulada das questões ambientais locais, regionais, nacionais, } \\
\text { transfronteiriças e globais; }\end{array}$ \\
\hline & Respeito à liberdade e equidade de gênero; \\
\hline $\begin{array}{l}\text { Descentralização } \\
\text { Espacial e } \\
\text { Institucional; }\end{array}$ & $\begin{array}{l}\text { Reconhecimento da diversidade cultural, ética, racial, genética, de espécies } \\
\text { e de ecossistemas; }\end{array}$ \\
\hline $\begin{array}{l}\text { Sustentabilidade } \\
\text { Socioambiental; }\end{array}$ & $\begin{array}{l}\text { Enfoque humanista, histórico, crítico, político, democrático, participativo, } \\
\text { inclusivo, dialógico, cooperativo e emancipatório; }\end{array}$ \\
\hline \multirow{6}{*}{$\begin{array}{c}\text { Democracia e } \\
\text { Participação Social; } \\
\text { Aperfeiçoamento e } \\
\text { Fortalecimento dos } \\
\text { Sistemas de Ensino, } \\
\text { Meio Ambiente e } \\
\text { outros que tenham } \\
\text { interface com a EA. }\end{array}$} & Compromisso com a cidadania ambiental; \\
\hline & $\begin{array}{l}\text { Vinculação entre as diferentes dimensões do conhecimento; entre os valores } \\
\text { éticos e estéticos; entre a educação, a cultura, e as práticas sociais; }\end{array}$ \\
\hline & $\begin{array}{c}\text { Democratização na produção e divulgação do conhecimento e fomento à } \\
\text { interatividade na informação; }\end{array}$ \\
\hline & $\begin{array}{l}\text { Pluralismo de ideias e concepções pedagógicas; } \\
\text { Garantia de continuidade e permanência do processo educativo; }\end{array}$ \\
\hline & Permanente avaliação crítica e construtiva do processo educativo; \\
\hline & $\begin{array}{l}\text { Coerência entre o pensar, o falar, o sentir e o fazer; } \\
\text { Transparência. }\end{array}$ \\
\hline
\end{tabular}

Fonte: Brasil (2005, p. 33 - 37)

A PNEA teve sua regulamentação através do decreto 4.281/02 o que possibilitou em 2003 a constituição do Órgão Gestor (OG) previsto no artigo 14 da Lei 9.795/99, cuja responsabilidade é implementar os programas e projetos desenhados no âmbito do ProNEA (BRASIL, 2006; LUCA, 2013).

O OG da PNEA é dirigido pelos ministros de meio ambiente e educação representado pela Diretoria de Educação Ambiental do Ministério do Meio Ambiente (DEA/MMA), instalada na Secretaria Executiva; e pela Coordenação Geral de Educação Ambiental do Ministério da Educação (CGEA/MEC), instalada na Secretaria de Educação Continuada, Alfabetização e Diversidade (SECAD). O OG é ainda assessorado por um Comitê Assessor, composto por treze representações da sociedade civil e de instituições federais, estaduais e municipais (BRASIL, 2005, p. 07). 
O Comitê Assessor tem a função de "assessorar o Órgão Gestor no planejamento e avaliação de diretrizes e ações relativas ao processo de implementação da PNEA" constituindo-se em uma "instância de controle social dessa política pública, e uma das vias para o enraizamento da educação ambiental no Brasil” (BRASIL, 2006, p.11).

Dentre as estratégias definidas pelo ProNEA destaca-se o incentivo à criação e fortalecimento das Comissões Estaduais Interinstitucionais de Educação Ambiental - CIEAs as quais espelhadas no OG da PNEA, devem formular seus próprios órgãos gestores estaduais e seus comitês assessores. Para o OG da PNEA, as CIEAs "têm como missão mais ampla propor as diretrizes da Política e do Programa Estadual de Educação Ambiental, coordenando e interligando as atividades relacionadas à educação ambiental” (BRASIL, 2005, p. 07).

\subsection{Breve apresentação da Comissão Interinstitucional Municipal de Educação Ambiental de Suzano}

Suzano é uma cidade paulista localizada na região do Alto Tietê. Sua extensão territorial é de $206 \mathrm{~km}^{2}$ e de acordo com o Censo 2010, possui aproximadamente 279 mil habitantes. Dentre as cidades da região, foi a primeira a constituir sua política municipal de meio ambiente, e a primeira no estado de São Paulo a constituir uma Comissão Interinstitucional de Educação Ambiental (CIMEA).

Uma nota se faz necessária para enfatizar que o estado de São Paulo permaneceu até agosto de 2013 como o único estado da federação que não havia constituído uma Comissão Interinstitucional Estadual de Educação Ambiental (CIEA).

A CIMEA-Suzano, instituída pelo decreto municipal 8068/11, é um "colegiado gestor deliberativo, formado por segmentos da sociedade civil, setor privado e poder público com atuação no município de Suzano e região, sendo representado por membros titulares e suplentes". Caracteriza-se como um "fórum permanente de diálogos, reflexões, construções, produções e tomadas de decisão sobre a busca da qualidade de vida, justiça socioambiental e proteção do meio ambiente" além de assumir a função de "contribuir na construção, [...] participar, apoiar, acompanhar e avaliar a política, o sistema e o programa de educação ambiental do município" (PREFEITURA MUNICIPAL DE SUZANO, 2012, p. 16).

A criação da CIMEA-Suzano foi coordenada pela Secretaria Municipal de Meio Ambiente com a cooperação técnica do Instituto Brasileiro de Educação, Ciência e Cultura - 
Comissão Estadual de São Paulo da Unesco - IBECC-Unesco para a realização de um processo de autoformação dos membros da CIMEA.

\begin{abstract}
O processo contemplou a socialização de experiências institucionais, com a elaboração do cardápio de ofertas e demandas do grupo; a criação de instrumentos legais de institucionalização da própria comissão; a construção do projeto político-pedagógico (PPP), com reflexão, diálogo e definição dos marcos conceitual, situacional e operacional, incluindo o reconhecimento do município (PREFEITURA MUNICIPAL DE SUZANO, 2012, p. 51).
\end{abstract}

As atividades da CIMEA-Suzano são orientadas pelo seu Projeto Político-Pedagógico (PPP), o qual estabeleceu um calendário de reuniões ordinárias para garantir o cumprimento dos papéis centrados em duas frentes: a gestão e a autoformação.

A gestão compreende as ações de criação e implementação de instrumentos legais (regimento interno, lei municipal de educação ambiental, fortalecimento do Plano Diretor do Comdema, Fundo Municipal do Meio Ambiente e Educação Ambiental, entre outros), comunicação interna e externa, arquivo e sistematização de relatórios, facilitação dos grupos de trabalhos, reuniões ordinárias e extraordinárias. No que se refere à autoformação, o PPP orienta a prática contínua de socialização das experiências do grupo, a realização de visitas técnicas, trabalhos de campo e participação em oficinas, palestras e eventos. (PREFEITURA MUNICIPAL DE SUZANO, 2012).

O PPP da CIMEA-Suzano ao centrar suas orientações no processo de autoformação dos membros indica uma postura de preocupação em atender a diversidade e por vezes a rotatividade de atores que a compõe. Cerca de 40 instituições constituíram o quadro de membros da CIMEA no período 2009 - 2012, oriundas dos mais variados setores públicos e não públicos da sociedade. Com exceção das secretarias municipais de meio ambiente e educação que compõem o OG da CIMEA-Suzano, todas as outras instituições participaram deliberadamente como membros, ocupando inclusive os grupos de trabalho na comissão e a secretaria executiva. Contudo, a diversidade de atores traz consigo uma diversidade de entendimentos e posturas, algumas com pouca ou nenhuma relação com a práxis e a teoria da EA, tornando o processo de autoformação dos membros indispensável à manutenção de suas ações à luz da PNEA. 


\section{GOVERNANÇA COLABORATIVA}

A literatura estrangeira, principalmente norte-americana, europeia e australiana, nos apresenta uma forma de governança que vem sendo adotada na gestão de recursos naturais ${ }^{7}$ e na administração pública ${ }^{8}$. Definida como governança colaborativa, esta forma de governança tem sido objeto de estudo de cientistas sociais para entender e contextualizar o engajamento de atores não governamentais em processos deliberativos de formulação e implementação de políticas públicas.

Nesta pesquisa, a teoria da governança colaborativa instrumentaliza a reflexão sobre o modelo de atuação e interação das instituições não governamentais e governamentais dentro da CIMEA-Suzano. O modelo colaborativo expressa a prática da comissão, assim como a prática da EA de maneira geral, para além da participação passiva da sociedade nos processos que envolvem políticas públicas.

Uma ideia de participação passiva pode ser reconhecida em Blackmore (2006, pág. 32), que sintetiza a participação como uma diversidade de iniciativas, dentre elas os workshops e grupos focais entre outros tipos de ações coletivas, importantes para ampliar o processo de aprendizagem social na atuação da sociedade nas políticas públicas, mas dependente da vontade e interesse dos governos em considerar suas proposições nas tomadas de decisão. Neste caso a participação da sociedade se dá como uma consulta dos seus interesses.

Diferente de Blackmore, em Wanna (2008) identificamos como os governos vêm modificando sua postura de únicos realizadores das políticas públicas para facilitadores de processos colaborativos que permitem a participação ativa da sociedade nas tomadas de decisão. Para Wanna, os processos colaborativos podem ser conduzidos por três vetores: os vetores externos relacionados à necessidade dos governos interagirem e se conectarem com conhecimentos detidos por outras organizações, assim como as respostas às pressões externas de interesses econômicos, culturais, ambientais, ou ainda o atendimento a padrões internacionalmente aceitos; os vetores internos são as respostas às demandas do funcionalismo público e da comunidade política; e a vontade, expressa como o "desejo de um

\footnotetext{
${ }^{7}$ BENTRUP, 2001; McDOUGALL e col., 2013; SELIN; CHAVEZ, 1995; SELIN, 2012

${ }^{8}$ EMERSON e col., 2011; FREEMAN, 1997; McGUIRE, 2006; MORSE, 2011; NEWMAN e col., 2004;

PROVAN; KENIS, 2007; PURDY, 2012; ROBERTSON; CHOI, 2012; SKELCHER; MATHUR; SMITH, 2005
} 
novo ativismo no governo, para desenvolver novas agendas políticas, assumir responsabilidades mais amplas e refazer quadros políticos” (WANNA, 2008, p. 08).

Nesta pesquisa, assume-se o entendimento de que a administração municipal de Suzano, ao requerer o envolvimento de uma variedade de instituições e pessoas em um processo de construção de uma agenda de políticas públicas de EA para o município, se colocou como uma facilitadora de um processo colaborativo, oportunizando a participação ativa da sociedade na tomada de decisão. Voltando-se à Wanna, a Política Municipal de Educação Ambiental de Suzano teve como vetores a vontade institucional da prefeitura e a colaboração dos conhecimentos e práticas das diversas instituições que compuseram a CIMEA-Suzano.

\subsection{Origem e conceito do termo Governança Colaborativa}

Há pelo menos cinco décadas a teoria da governança colaborativa vem sendo discutida na arena acadêmica (EMERSON, NABATCHI e BALOGH, 2011). Entretanto, os estudos sobre a governança, um pouco mais antigos que os estudos sobre governança colaborativa, fundamentam a trajetória da administração pública no cenário mundial facilitando o entendimento da entrada dos processos colaborativos na gestão pública.

Tomamos a década de 1990 como o período de difusão do conceito de boa governança empreendido pelo Banco Mundial como critério de empréstimo para países em desenvolvimento, para os quais, a governança deveria compor um conjunto adequado de práticas democráticas e de gestão que os ajudariam a melhorar suas condições de desenvolvimento econômico e social (RONCONI, 2011; SECCHI, 2009).

Adotar a boa governança significou para muitos países, entre eles o Brasil, o empreendimento de reformas da gestão pública. “A reforma de gestão pública geralmente pressupõe uma reforma do serviço público que crie um serviço público profissional em um dado país" (BRESSER-PEREIRA, 2009, pág. 241), no entanto, a maior parte destas reformas foi conduzida por economistas, que, "à parte da ideia de serviço público profissional, reduziram a reforma da gestão pública a um ajuste estrutural, às privatizações e enxugamento" (Ibid, p. 242).

Ao final da década de 1930 o Brasil experimentou uma reforma na gestão pública sob o comando de Getúlio Vargas, mas em 1995 uma reforma maior foi empreendida no Governo 
Fernando Henrique Cardoso, "período a partir do qual o país incorpora os ajustes econômicos de corte neoliberal, de ajuste estrutural e de políticas sociais compensatórias" (RONCONI, 2011, pág. 24).

Bevir (2009) atenta para uma abordagem neoliberal da governança, que, aliada à Teoria da Escolha Racional, pressupõe o aumento de eficiência no setor público supostamente garantido pela mercantilização, contratações externas, cortes de pessoal e rigor no orçamento; o Estado ao invés de prestar serviços, desenvolve um sistema empresarial baseado na concorrência e nos mercados.

Esta penetração das leis de mercado na administração pública é definida por Lima (2007, p.157) enquanto uma "estratégia gerencialista" de minimização da ação do Estado. Seu exemplo mais conhecido, denominado como Nova Gestão Pública (New Public Management), trata-se de "uma transformação de paradigma na governança pública que aplica ao serviço público mecanismos característicos do mercado" (BARDOUILLE, 20009 apud LIMA, 2007, p. 158).

O mercado, aqui entendido como um mecanismo de ordem e coordenação de um sistema (econômico, por exemplo) sem um centro coordenador consciente, que estimula a competição com o uso de incentivos econômicos, implicando, em algumas vezes, no enfraquecimento de sistemas burocráticos.

Um resumo das características que compõe o gerencialismo está compreendido na

descentralização do aparelho do estado, privatização das estatais, terceirização dos serviços públicos meios, regulação estatal das atividades públicas conduzidas pelo setor privado realizada pelas Agências Reguladoras - e a utilização de ferramentas gerenciais advindas do setor privado como, por exemplo, os contratos de gestão (RAQUEL, 2012, p.64).

O Estado passa a compartilhar papéis e responsabilidades na entrega de serviços com outras instituições, acreditando desta forma que melhorariam os métodos de entrega dos serviços ao especificar quais resultados ou realizações queriam, ao monitorar fornecedores externos e controlar os preços (WANNA, 2008, p. 06).

Há, nesse sentido, segundo Ronconi (2011, p. 25)

\footnotetext{
${ }^{9}$ BARDOUILLE, N. C. The transformation of governance paradigms and modalities: insights into the marketisation of the public service in response to globalization. The Round Table, n. 353, p. 81-106, 2000.
} 
A transformação do Estado que produz o bem público em um Estado que garante a produção do bem público; de um Estado ativo que provê solitário o bem público, em um Estado ativador que aciona e coordena outros atores a produzirem o bem público com ele; de um Estado dirigente ou gestor em um Estado cooperativo, que em conjunto com diversos atores produz o bem público.

A manutenção de um Estado gerencialista não obteve o contento necessário para se perpetuar. $\mathrm{O}$ modelo não demonstrou capacidade para economizar recursos ou reduzir custos operacionais, provocando até mesmo a redução dos postos de trabalho na administração pública (KISSLER; HEIDEMANN, 2006; LIMA, 2007), aumento da polarização dos rendimentos e dos níveis de riqueza e o aumento generalizado da corrupção (SANTOS, B., 2005).

Em meio a outras críticas, o modelo gerencialista foi enfraquecido e cedeu lugar ao arquétipo de governança que Denhardt e Denhardt (2003) chamaram de Novo Serviço Público. Este modelo contempla uma teoria política democrática que se preocupa com a conexão entre os cidadãos e seus governos, abordagens alternativas à gestão e ao modelo organizacional, cujo enfoque seria mais humanista em que o bem público ou o serviço público é coproduzido com a sociedade e pela sociedade (RAQUEL, 2012; RONCONI, 2011; CAPOBIANGO e col., 2013).

O Novo Serviço Público representa, segundo Kissler e Heidemann (2006, p. 482) uma "tendência para se recorrer cada vez mais à autogestão nos campos social, econômico e político, e a uma nova composição de formas de gestão daí decorrentes".

O termo governança "diz respeito à capacidade de ação estatal na implementação das políticas e na consecução das metas coletivas” (DINIZ, 2001, p.21). Newman e col. (2004, p. 204) tomam o termo referindo-se a "padrões de tomada de decisão que ocorrem em um conjunto maior de instituições, com uma ampla gama de atores e processos", onde a participação destes atores "ocorre para além dos procedimentos estabelecidos da democracia representativa".

De maneira geral o termo governança refere-se ao ato de governar, seja no setor público ou privado e governança colaborativa é o que atinge os conceitos mais amplos da administração pública e da democracia, onde atores de diferentes grupos, públicos ou privados, trabalham coletivamente para desenvolver ou implementar leis ou políticas destinadas ao bem público. (ANSELL;GASH, 2007; EMERSON; NABATCHI; BALOGH, 2011, PURDY, 2012; ROBERTSON; CHOI, 2012). 

como

Ansell e Gash (2007, p. 544) nos apresenta o conceito de governança colaborativa Um arranjo governamental onde um ou mais agentes públicos engajam atores não governamentais em um processo coletivo de tomada de decisão que é formal, orientado pelo consenso e deliberativo, e que objetiva fazer ou implementar políticas públicas ou gerenciar programas públicos ou ativos.

Esta é uma conceituação recorrente nas referências consultadas que tratam da identificação de modelos de governança colaborativa (EMERSON; NABATCHI; BALOGH, 2011; JAGANNATH, 2013; JOHNSTON e col., 2010; MORSE, 2011; ROBERTSON; CHOI, 2012).

Emerson, Nabatchi e Balogh (2012, p. 03) propõem ampliação deste conceito ao incorporar a ideia de multipartner governance, que significa "parceria entre o Estado, o setor privado, a sociedade civil e a comunidade, bem como as modalidades de governo e arranjos híbridos, como as parcerias público-privado e privado-social e os regimes de co-gestão", em referência aos tipos de arranjos que podem existir entre entes governamentais e não governamentais.

Outros autores conceituam governança colaborativa a partir de outras nomenclaturas baseando-se, por exemplo, nos contextos do engajamento de atores não governamentais em processos decisórios ou no contexto da administração pública. McDougall e colaboradores (2013) centram o conceito de governança colaborativa no engajamento dos atores, considerando os esforços que realizam para exercer seus direitos, executarem papéis de liderança e na integração efetiva de suas vozes nos grupos decisores. Newmann e colaboradores (2004, p. 205) identificam como um "projeto político" para engajar os cidadãos na resolução de problemas, assim como uma "presença política" que permite ao cidadão incluir seus interesses, conhecimentos e identidade nos processos deliberativos veiculados a fóruns deliberativos.

No contexto da administração pública Morse (2011, p. 725) contabiliza um aumento acentuado na variedade de formas em que a administração pública se relaciona com outros setores. A variedade de formas a que se refere pode segundo o mesmo autor ser entendida sob a "bandeira da governança colaborativa", acrescentando ser esta variedade também conhecida como "gestão pública colaborativa".

Ronconi (2011), Kissler e Heidemann (2006) nomeiam como governança pública uma mudança na gestão política que se abre à participação de diversos atores e gera espaços 
públicos de participação e controle social. Enquanto que um "modelo híbrido de provisão de serviços" pode ser visto segundo Jagannath (2013, p. 190) pelas "lentes da governança colaborativa".

Outra denominação que abarca o conceito de governança colaborativa também pode ser reconhecida sob a nomenclatura de planejamento colaborativo (HAJER e WAGENAAR, 2003; BENTRUP, 2001).

\subsection{Desenho}

Com apoio nas definições conceituais de governança colaborativa é possível identificar o desenho pelo qual o modelo se projeta. As referências bibliográficas consultadas exprimem o modo como o modelo de governança colaborativa está estruturado, identificando os arquétipos de relações entre as partes indispensáveis para seu reconhecimento.

A governança colaborativa se dá como um "processo de facilitação e operação em arranjos multiorganizacionais que tem o fim de resolver os problemas que não podem ser resolvidos - ou facilmente resolvidos - por organizações individuais" (McGUIRE, 2006, p. 33). Purdy (2012, p. 409) citando Gray (1989) descreve colaboração como "um processo através do qual as partes que veem diferentes aspectos de um problema pode construtivamente explorar suas diferenças e procurar soluções que vão além de sua própria visão limitada do que é possível". 10

De acordo com Ansell e Gash (2007, p. 545) o processo colaborativo na gestão pública tem início no próprio ente público, ao acreditarem que os "órgãos públicos tem um papel de liderança distintivo na governança colaborativa". Os autores incluem em suas análises a necessidade de não criar apenas ambientes consultivos, mas garantir o que Johnston e colaboradores (2009, p. 700) definem como um "compromisso fundamental de inclusão nos fóruns colaborativos de todas as pessoas afetadas por um problema, onde esses problemas são discutidos e soluções para eles são formuladas".

Desta forma, infere-se com apoio de Freeman (1997) que o processo colaborativo na gestão pública não deve dispensar quatro requisitos: resolução de problemas, ampla

\footnotetext{
${ }^{10}$ GRAY, B. Collaborating: Finding commom ground for multiparty problems. San Franciso : Jossey Bass, 1989.
} 
participação, divisão de responsabilidades entre atores públicos e privados nas regulamentações além do envolvimento de uma agência pública flexível.

Já Ansell e Gash (2007) desdobram os requisitos em seis pontos a partir de (1) um fórum iniciado por agentes públicos, (2) com a participação de agentes não públicos e (3) engajados, não meramente consultados, (4) atuantes em fóruns formais (5) cujas deliberações são balizadas pelo consenso e (6) o foco da colaboração é em gestão e políticas públicas.

\subsection{Modelos de Governança Colaborativa}

Ainda que Freemann (1997) e Ansell e Gash (2007) tenham colaborado com a definição de requisitos necessários para o reconhecimento da governança colaborativa, outros meios de verificação se desdobraram na intenção de reconhecer uma situação colaborativa na gestão pública ou mesmo de avaliar se o processo colaborativo atinge os resultados esperados.

A literatura consultada apresenta pelo menos dois tipos de análises para governança colaborativa, divididos entre frameworks e modelos. Uma diferenciação entre eles é colocada por Ostrom (2005) e se faz pertinente para a compreensão dos arquétipos analisados nesta pesquisa.

O desenvolvimento e uso de modelos implica em focar a análise em um conjunto limitado de informações e variáveis, objetivando explorar as consequências destas suposições sistematicamente, enquanto que o desenvolvimento e uso de frameworks (quadros) está geralmente associado à identificação de elementos e a associação entre eles, compreendendo uma alternativa de análise que busca criar um conjunto de informações e relacioná-las entre si, sendo um instrumento mais bem utilizado para análise de teorias do que os modelos (OSTROM, 2005).

Emerson, Nabatchi e Balogh (2011, p. 05) desenvolveram um framework para compreender, desenvolver e testar teorias relacionadas à governança colaborativa. Este Quadro Integrador para Governança Colaborativa é representado na figura 1 apresentando três dimensões aninhadas, mostradas como caixas, representando o contexto geral do sistema, o Regime de Governança Colaborativa (RGC) e sua dinâmica e ações colaborativas. 
Figura 1 - Quadro Integrativo para Governança Colaborativa

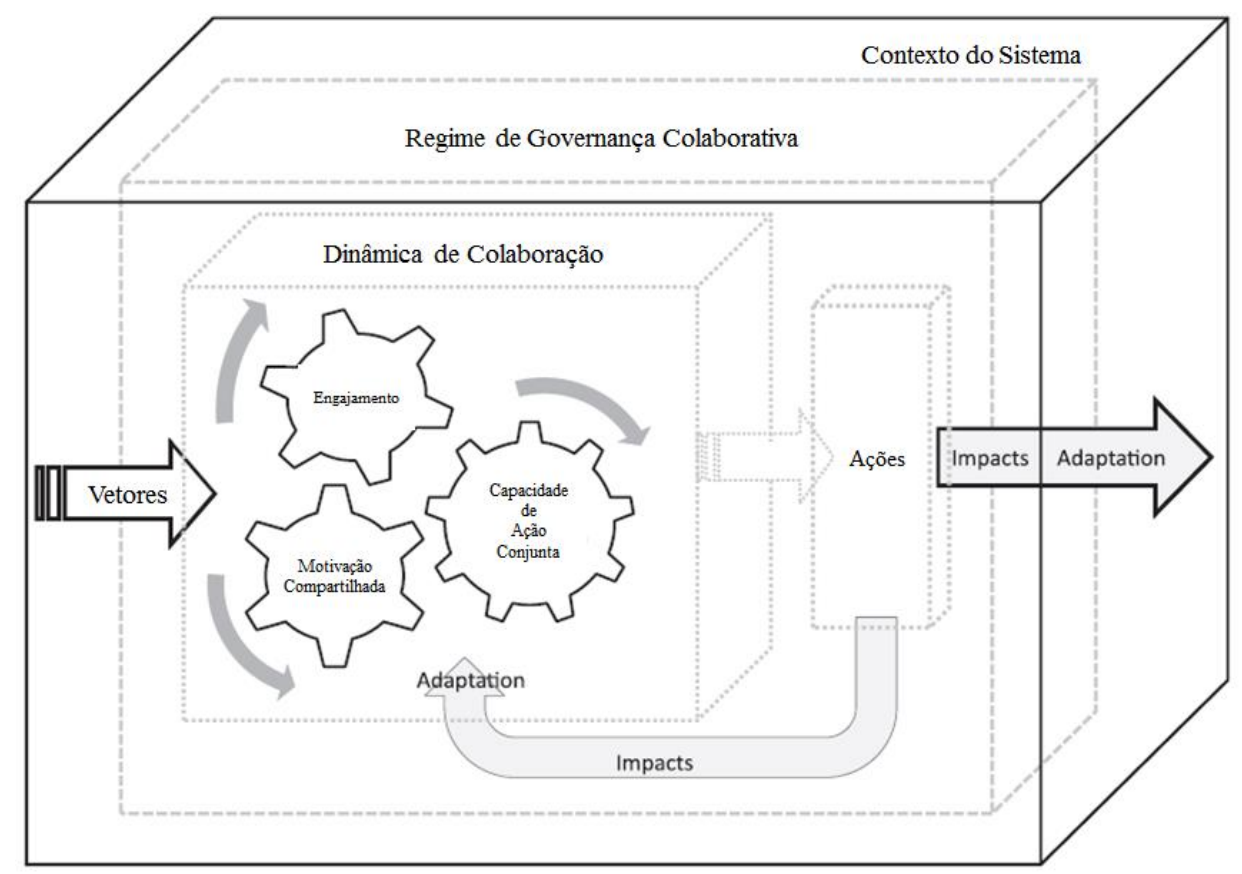

Fonte: Emerson, Nabatchi e Balogh (2011, p. 06)

Selin e Chavez (1995), baseados em pesquisas sobre processos colaborativos (GRAY, 1985, 1989; MCCANN, 1983; WADDOCK, 1989) desenvolveram um modelo conceitual identificando componentes potencialmente chaves no planejamento baseado em colaboração (BENTRUP, 2001).

Figura 2 - Modelo Colaborativo para Planejamento Ambiental

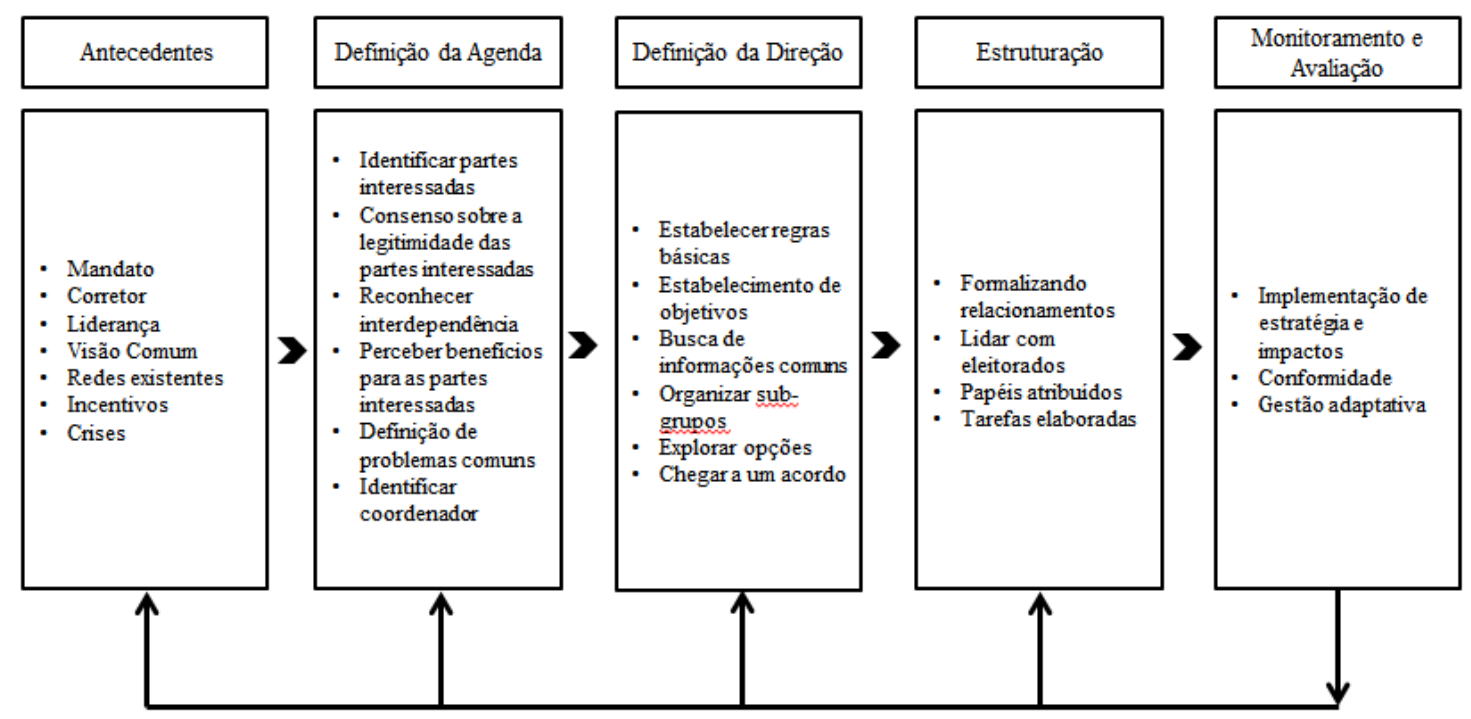

Fonte: Adaptado de Bentrup (2001, p. 741) e Selin e Chavez (1995, p. 191) 
Ansell e Gash (2007, p. 562) também oferecem um quadro de análise da teoria da governança colaborativa, no qual acreditam ser possível "organizar uma série de proposições contingentes e de relacionamento de causa e efeito" com potencial para "fornecer uma base para futuros testes empíricos e elaboração de teorias". Contudo, apesar da diferenciação entre quadros e modelos construída por Ostrom (2005), e do tipo de análise construída relacionar-se muito bem a tipologia de quadros, os autores o nomeiam como Modelo de Governança Colaborativa.

\section{Figura 3 - Modelo de Governança Colaborativa}

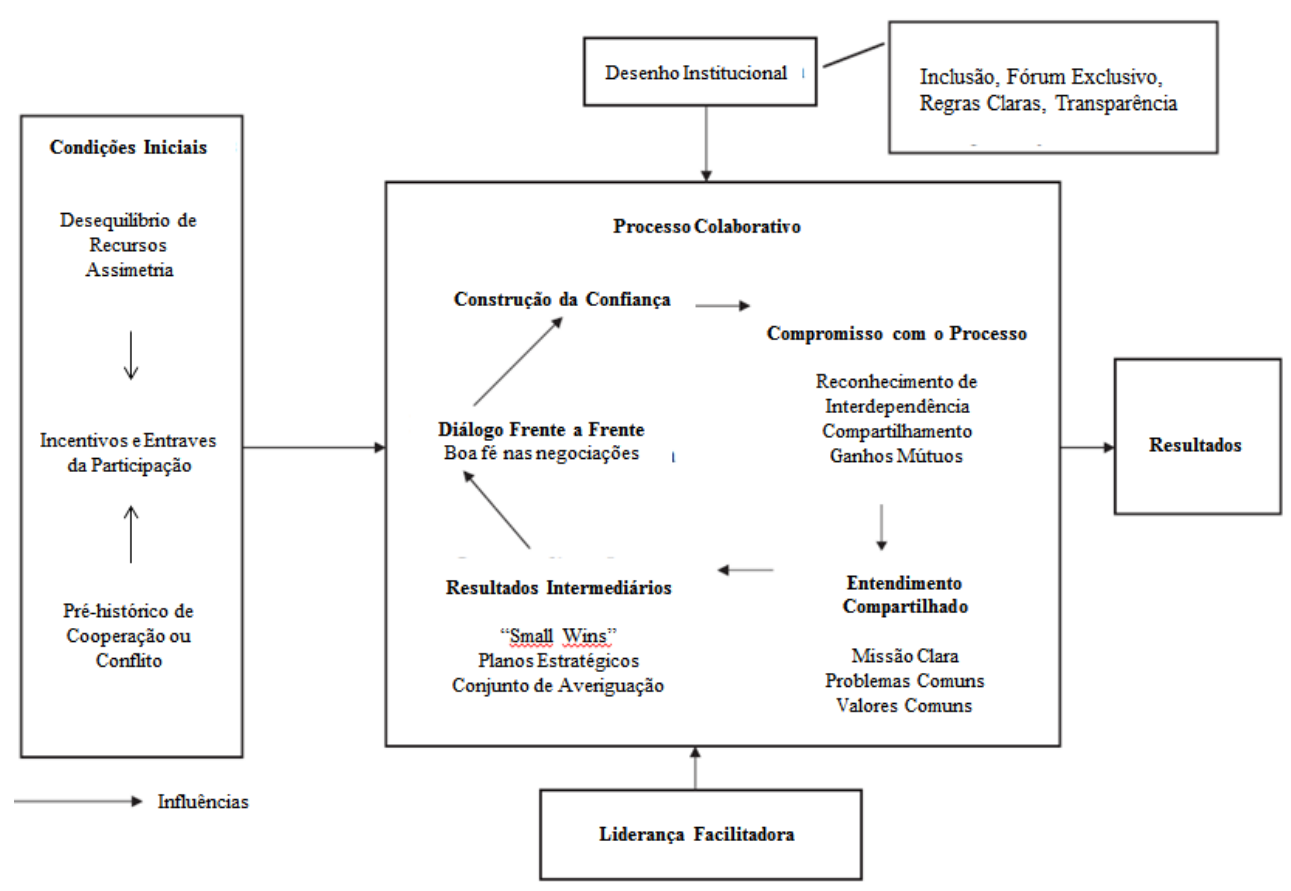

Fonte: Ansell e Gash (2007, p. 550)

Ao voltar-se aos objetivos deste trabalho de pesquisa - examinar a implementação e atuação da CIMEA-Suzano como um caso de governança colaborativa no provimento de políticas públicas de Educação Ambiental - verifica-se que as concepções de quadros ou modelos definidas por Ostrom (2005) não limita a escolha de um ou de outro para encaminhamento desta análise.

Há na verdade a possibilidade de conjugar a identificação de elementos e a associação entre eles (quadros) com a análise sistemática do conjunto destes elementos (modelos) de forma que se produza uma compreensão abrangente da estrutura colaborativa em que a CIMEA-Suzano está colocada. 
Para fins deste trabalho de pesquisa, optou-se por denominar como Modelos de Governança Colaborativa o conjunto de três experiências de análise do conceito de governança colaborativa que resultaram em arquétipos; assim como distinguir duas dimensões dentre os Modelos de Governança Colaborativa: a dimensão do Pré - Processo Colaborativo que reúne as condições e os recursos necessários ao início do processo colaborativo, e a dimensão do Processo Colaborativo em si, onde se reconhece os mecanismos que identificam sua prática.

\subsubsection{Pré - processos Colaborativos}

O que precede e viabiliza o processo colaborativo é aqui entendido como as condições e atitudes previamente estabelecidas, ou reconhecidas, no contexto da participação dos entes não governamentais na elaboração, implementação ou avaliação de políticas públicas.

Nos modelos de governança adotados para esta análise, encontramos diferentes denominações e condicionantes para os processos que iniciam ou preparam a colaboração. Ansell e Gash (2007, p. 550) nomeiam como Condições Iniciais "as condições presentes no início da colaboração que podem facilitar ou desencorajar a cooperação entre as partes interessadas e entre as agências e as partes interessadas". Os autores consideram como um fator decisivo para a colaboração a predisposição entre as instituições em colaborar entre si, dependendo do histórico de relacionamento entre elas, além dos recursos próprios que cada instituição possui para viabilizar sua participação.

Selin e Chavez (1995, pág. 191) apoiaram-se em Waddock (1989) ${ }^{11}$ para descrever a fase nomeada como Antecedentes, esta caracterizada por sete forças que levam à situação de colaboração entre instituições e governos. Bentrup (2001), ao analisar os esforços do planejamento da gestão de uma bacia hidrográfica através do modelo de Selin e Chavez (1995), identificou duas forças adicionais: a falta de dados e a ameaça aos regulamentos.

\footnotetext{
${ }^{11}$ WADDOCK, S. A. Understanding social partnerships: An evolutionary model of partnership organizations. Administration and Society, v. 21, p. 78-100, 1989.
} 
Tabela 2 - Antecedentes

\begin{tabular}{r|l}
\hline \multicolumn{1}{c}{ Forças que levam à colaboração } \\
\hline Crises & $\begin{array}{l}\text { As crises podem culminar na necessidade de tomada de decisões que envolvam } \\
\text { todos os afetados pelo problema em questão; }\end{array}$ \\
\hline Mantes & $\begin{array}{l}\text { Instituições podem realizar a mediação de conflitos propondo uma tomada de } \\
\text { decisão conjunta; }\end{array}$ \\
\hline Visão Comum & $\begin{array}{l}\text { Os processos colaborativos podem ser desencadeados pelos próprios governos ou } \\
\text { por instituições que determinem a participação do ente não público } \\
\text { mandatoriamente; }\end{array}$ \\
\hline Oedes Existentes & $\begin{array}{l}\text { Uma rede de instituições que compartilham visões comuns pode proporcionar um } \\
\text { processo colaborativo na tomada de decisões; }\end{array}$ \\
\hline Liderança & $\begin{array}{l}\text { Lideranças pessoais ou institucionais podem estimular o engajamento de atores } \\
\text { não governamentais na tomada de decisão de políticas públicas; }\end{array}$ \\
\hline Incentivos & $\begin{array}{l}\text { Recursos materiais e imateriais podem alavancar processos colaborativos nas } \\
\text { tomadas de decisões; }\end{array}$ \\
\hline Regulame de Dados & $\begin{array}{l}\text { A falta de dados cria um sentimento de incerteza, que pode conectar as pessoas } \\
\text { na resolução dos problemas gerados por este motivo; }\end{array}$ \\
\hline \begin{tabular}{l} 
Incentiva as partes interessadas a trabalhar em conjunto para evitar penalizações. \\
\hline
\end{tabular}
\end{tabular}

Fonte: Adaptado de Selin e Chavez (1995) e Bentrup (2011)

No Quadro Integrativo para Governança Colaborativa, os autores Emerson, Nabatchi e Balogh (2012, pág. 8), citando Borrini-Feyerabend (1996) ${ }^{12}$, sentenciam que a "governança colaborativa é iniciada e evolui dentro de um contexto de múltiplas camadas de política, influências legais, socioeconômicas, ambientais e outras influências". Este contexto do sistema é externo ao processo colaborativo, mas completamente influente e influenciável.

O modelo discrimina as situações que influenciam a colaboração entre as instituições, sendo elas as condições e recursos, regulamentações, falhas de abordagem, dinâmicas políticas e relações de poder, grau de conectividade entre as redes existentes, histórico de conflitos, interesses mútuos e confiança entre as instituições. Diametralmente, estas condições e recursos podem ser influenciados ao passo que o processo colaborativo avança.

\subsubsection{Processos Colaborativos}

Os processos colaborativos identificados nos modelos selecionados para esta pesquisa, diferente dos pré-processos, podem exprimir um ponto de partida ou uma sequencia préestabelecida de ações no seu avanço. Neste sentido, Selin e Chavez (1995) se mostram bastantes claros na progressão de uma fase à outra.

\footnotetext{
${ }^{12}$ BORRINI-FEYERABEND, G. Collaborative management of protected areas: Tailoring the approach to the context. Gland : IUCN, 1996.
} 
Figura 4 - Fases do Processo Colaborativo em Selin e Chavez (1995)

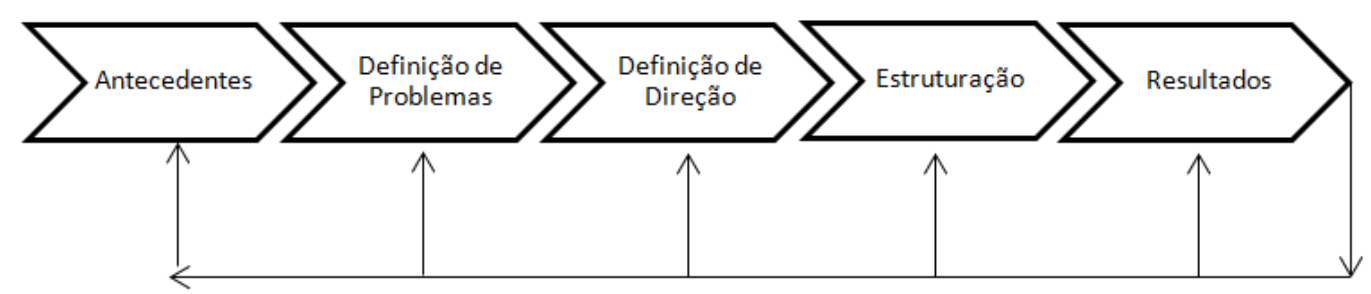

Fonte: Adaptado de Selin e Chavez (1995).

Cada fase contempla um conjunto de situações e recursos que procedem à próxima fase à medida que são percebidas ou executadas. "Deve-se ressaltar que este modelo descreve um conjunto ideal de circunstâncias que são muitas vezes atenuadas por obstáculos internos e externos para colaboração" (Selin e Chavez, 1995, pág. 190).

Tendo-se em conta que se trata aqui de um modelo para a teoria de governança colaborativa, é possível afirmar que o prosseguimento de uma fase para a outra não requer que todas as circunstâncias sejam categoricamente cumpridas. Contudo, o modelo não expõe uma razão mínima entre as circunstâncias alcançadas ou não para se determinar uma situação colaborativa.

A fase Antecedentes é compreendida nesta pesquisa como um pré-processo colaborativo, detalhado anteriormente. A fase seguinte, Definição de Problemas, se caracteriza pelo consenso das instituições sobre a natureza de um determinado problema/desafio, que leva ao conhecimento da interdependência entre as instituições para enfrentá-lo/conquistá-lo e o alcance de benefícios mútuos entre elas para tanto. A fase seguinte, Definição de Direção, complementa a clareza sobre os problemas/desafios consensuados e define a estratégia para enfrentá-lo/conquistá-lo, pois está caracterizada pelo compartilhamento e análise de informações relevantes. Operacionalmente são estabelecidos os objetivos, regras e criados grupos e subgrupos de trabalho. A fase de Estruturação envolve a institucionalização destes grupos.

Assim como Emerson, Nabatchi e Balogh (2012) assumem que o processo colaborativo pode influenciar no contexto do sistema em que este processo colaborativo está inserido, Selin e Chavez também admitem interferências da fase de Resultados nas fases que a precedem, determinando assim um ciclo. A fase Resultados não expressa o fim do processo colaborativo, mas ilustra a natureza interativa e cíclica da colaboração, onde as instituições 
acordam programas e o implementam, avaliam os impactos e reavaliam o interesse em permanecer colaborando (Selin e Chavez, 1995).

Para Ansell e Gash (1997) o processo colaborativo também se expressa como um ciclo entre comunicação, confiança, compromisso, entendimento e resultados. O modelo proposto pelos autores expressa a preocupação em não dar linearidade ao processo colaborativo, ao contrário, busca criar uma dinâmica na qual as influências de cada fase - negativas ou positivas - possam ser conhecidas e avaliadas.

O processo colaborativo se inicia pelo Diálogo Frente a frente, uma espécie de negociação entre instituições sobre seus objetivos individuais, identificação de oportunidades e ganhos mútuos. É uma fase importante para esclarecer os posicionamentos, e, principalmente, dirimir questões de antagonismo entre as instituições.

A disposição para vencer as diferenças entre as instituições pode não ser o suficiente para que elas se engajam no processo colaborativo, há que se construir a confiança entre elas. Esta fase de Construção da Confiança pode ser caracterizada como um esforço de mediação entre as instituições de posições antagônicas. Os autores advertem que instituições que não ultrapassam os pontos de oposição à outra/outras instituições, não devem embarcar no processo colaborativo.

A fase seguinte, denominada Compromisso com o Processo, requer das instituições um compromisso maior do que a necessidade de terem suas opiniões e reivindicações conhecidas ou até mesmo legitimadas no grupo em que se encontram. Requer, sobretudo, um comprometimento primário de interesse de participar do processo colaborativo. Os autores apontam a barganha de ganhos mútuos como um caminho para o compromisso, mas atentam para o fato de que o compromisso com o processo não garante que os resultados alcançados sejam os desejáveis para algumas instituições.

Esta possibilidade reflete claramente a necessidade de ter os processos de Diálogo e Construção da Confiança consolidados, pois, as instituições que por algum motivo não percebem ganhos favoráveis a ela, podem vir a não aniquilar ou corromper o processo colaborativo se elas confiam que o conjunto das instituições têm objetivos compartilhados com ela inclusive - e que trabalham por um bem comum. 
A determinação deste bem comum se dá na fase de Compartilhar os Entendimentos ou compartilhamento da visão, objetivos, missão etc - entre as instituições. Também entendida como uma fase de aprendizagem do processo colaborativo, onde o compartilhamento dos entendimentos permite a criação de uma espécie de empatia entre as instituições, alcançada através da pactuação de seus objetivos e das lições aprendidas no processo colaborativo.

O processo colaborativo do modelo de Ansell e Gash (1997) prevê ainda duas interferências, uma delas o Desenho Institucional do processo, referente aos protocolos e regras básicas para a colaboração, que são fundamentais para a legitimidade do processo colaborativo; e a Liderança Facilitadora, crucial para a criação e manutenção das regras do jogo, construção da confiança, facilitação do diálogo e sondagem de ganhos.

No Desenho Institucional se examina, por exemplo, quais instituições interessam para o processo colaborativo, requerendo um balanço entre as instituições que compartilham objetivos e/ou problemas e as instituições que são historicamente excluídas dos processos de tomadas de decisão. A presença de uma Liderança Facilitadora pode ser determinante para apoiar justamente a participação destas instituições malogradas e balancear o poder entre estas e as instituições mais atuantes.

\subsection{Matriz do Processo Colaborativo}

Ainda que os modelos dos processos colaborativos sejam distintos entre si, e que se reconheça os diferentes momentos e bases de pesquisas que sustentam cada um, esta pesquisa verifica pertinência entre as diferentes fases que compõem os citados processos colaborativos e os reúne em uma Matriz do Processo Colaborativo.

Os modelos de governança colaborativa exibem conteúdos e sistemáticas semelhantes que podem ser observadas na descrição de suas fases. De maneira geral, preocupam-se com a distinção das fases que antecedem e viabilizam o processo colaborativo, como já mencionado e relevado nesta pesquisa, que se desdobram sobre as questões relacionadas, por exemplo, aos interesses mútuos de participação das instituições, suas forças e fraquezas.

$\mathrm{Na}$ matriz (tabela 3), uma coluna denominada Temas Interseccionais agrupa as pertinências percebidas nestas descrições, que serão tratadas na tabela 4 como pressupostos 
teóricos, por se tratarem de extratos baseados na literatura de referência dos modelos de governança colaborativa.

As tabelas 3 e 4 são assim complementares e representam apenas a função de aglutinação dos conteúdos que se assemelham com os conteúdos que são distintos nas referências teóricas sobre modelos colaborativos de governança 


\begin{tabular}{|c|c|c|c|}
\hline & FASES & AUTORES (ANO) & $\begin{array}{c}\text { TEMAS } \\
\text { INTERSECCIONAIS }\end{array}$ \\
\hline \multirow{23}{*}{ 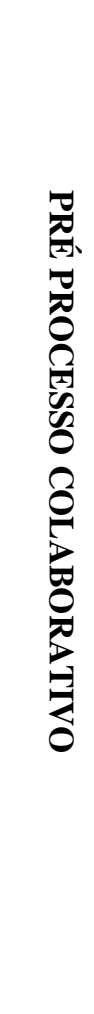 } & Assimetrias de Poder, Recursos e Conhecimentos & Ansell e Gash (2007) & \multirow{2}{*}{ Assimetria } \\
\hline & Dinâmica Política / Relações de Poder; Diversidade Socioeconômica / Cultural & Emerson, Nabatchi e Balogh (2011) & \\
\hline & Condições de Recursos / Políticas e Marcos Legais & Emerson, Nabatchi e Balogh (2011) & \multirow{6}{*}{ Recursos e Incentivos } \\
\hline & Incentivos & Selin e Chavez (1995) & \\
\hline & Incentivos Consequentes & Emerson, Nabatchi e Balogh (2011) & \\
\hline & Incentivos para a Participação & Ansell e Gash (2007) & \\
\hline & Mandato & Selin e Chavez (1995) & \\
\hline & Agentes & Selin e Chavez (1995) & \\
\hline & Pré-histórico de Antagonismo e Cooperação & Ansell e Gash (2007) & \multirow{2}{*}{ Conflitos Pré-existentes } \\
\hline & Níveis de Conflito / Confiança & Emerson, Nabatchi e Balogh (2011) & \\
\hline & Visão Comum & Selin e Chavez (1995) & \multirow{5}{*}{$\begin{array}{l}\text { Compartilhamento de } \\
\text { Interesses }\end{array}$} \\
\hline & Redes Existentes & Selin e Chavez (1995) & \\
\hline & Identificar Partes Interessadas & Selin e Chavez (1995) & \\
\hline & $\begin{array}{l}\text { Consenso entre Partes Interessadas; Definição de Problemas Comuns; Percepção da } \\
\text { Importância dos Benefícios das Partes Interessadas }\end{array}$ & Selin e Chavez (1995) & \\
\hline & Conectividade de Rede & Emerson, Nabatchi e Balogh (2011) & \\
\hline & Falhas na Abordagem & Emerson, Nabatchi e Balogh (2011) & \multirow{4}{*}{ Liderança } \\
\hline & Liderança & Selin e Chavez (1995) & \\
\hline & Liderança Facilitadora & Ansell e Gash (2007) & \\
\hline & Liderança & Emerson, Nabatchi e Balogh (2011) & \\
\hline & Interdependência & Emerson, Nabatchi e Balogh (2011) & \multirow{3}{*}{ Interdependência } \\
\hline & Crises & Selin e Chavez (1995) & \\
\hline & Reconhecer a Interdependência & Selin e Chavez (1995) & \\
\hline & Incerteza & Emerson, Nabatchi e Balogh (2011) & Incerteza \\
\hline \multirow{9}{*}{ 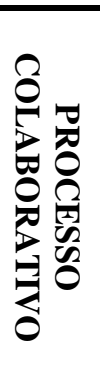 } & Diálogo Frente a Frente & Ansell e Gash (2007) & \multirow{2}{*}{ Diálogo } \\
\hline & Deliberação & Ansell e Gash (2007) & \\
\hline & Estabelecimento de objetivos e regras básicas & Selin e Chavez (1995) & \multirow{2}{*}{ Definição de Objetivos } \\
\hline & Definição & Emerson, Nabatchi e Balogh (2011) & \\
\hline & Busca de Informação Conjunta & Selin e Chavez (1995) & \multirow{3}{*}{$\begin{array}{l}\text { Compartilhamento de } \\
\text { Interesses }\end{array}$} \\
\hline & Descoberta & Emerson, Nabatchi e Balogh (2011) & \\
\hline & Exploração das Opções & Selin e Chavez (1995) & \\
\hline & Organização em Sub-Grupos & Selin e Chavez (1995) & \multirow{2}{*}{ Protocolo da Prática } \\
\hline & Formalização das Relações; Atribuição de Papéis; Elaboração de Tarefas & Selin e Chavez (1995) & \\
\hline
\end{tabular}


Determinação

Emerson, Nabatchi e Balogh (2011)

Arranjos Processuais / Institucionais

Emerson, Nabatchi e Balogh (2011)

Desenho do Sistema de Monitoramento e Avaliação

Construção da Confiança

Confiança Mútua

Compromisso com o Processo

Compromisso Compartilhado

Entendimento Compartilhado

Entendimento Mútuo

Resultados Intermediários

Liderança, Conhecimento e Recursos

Legitimidade Compartilhada

Selin e Chavez (1995)

Ansell e Gash (2007)

Emerson, Nabatchi e Balogh (2011)

Ansell e Gash (2007)

Emerson, Nabatchi e Balogh (2011)

Ansell e Gash (2007)

Emerson, Nabatchi e Balogh (2011)

Ansell e Gash (2007)

Emerson, Nabatchi e Balogh (2011)

Emerson, Nabatchi e Balogh (2011)

Confiança Mútua

Compromisso

Entendimento

Resultados

Liderança

Legitimidade

Fonte: Adaptado de Ansell e Gash (2007), Emerson, Nabatchi e Balogh (2011) e Selin e Chavez (1995) 
Tabela 4 - Pressupostos teóricos dos temas interseccionais

\begin{tabular}{|c|c|c|}
\hline & $\begin{array}{c}\text { Temas } \\
\text { Interseccionais } \\
\end{array}$ & Pressupostos Teóricos \\
\hline \multirow{7}{*}{ 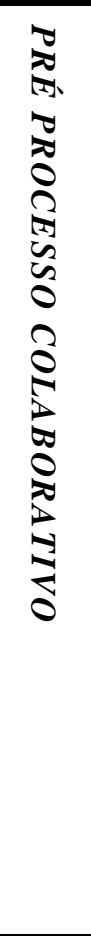 } & Assimetria & $\begin{array}{l}\text { Quando partes interessadas não têm a capacidade, a organização, status ou recursos para participar, ou participar } \\
\text { em pé de igualdade; Quando algumas partes podem não ter a habilidade e perícia para se envolverem em } \\
\text { discussões sobre problemas altamente técnicos. }\end{array}$ \\
\hline & $\begin{array}{l}\text { Recursos e } \\
\text { Incentivos }\end{array}$ & $\begin{array}{l}\text { Quando os recursos materiais e imateriais podem alavancar processos colaborativos nas tomadas de decisões; } \\
\text { Quando as questões apresentadas são importantes para os participantes e estes se encontram no momento } \\
\text { favorável ou estão pressionados por buscar soluções; Quando os incentivos são gerados pelos órgãos públicos no } \\
\text { patrocínio da governança colaborativa; Quando a participação é demandada pelos tribunais ou órgãos legislativos, } \\
\text { embora se saiba que a participação é tipicamente voluntária; Quando instituições mediam conflitos propondo uma } \\
\text { tomada de decisão conjunta. }\end{array}$ \\
\hline & $\begin{array}{l}\text { Conflitos Pré- } \\
\text { existentes }\end{array}$ & $\begin{array}{l}\text { Quando as partes interessadas percebem não alcançar seus objetivos sem se engajar em um processo de } \\
\text { colaboração com outras partes interessadas, cujos interesses são muitas vezes diametralmente opostos. }\end{array}$ \\
\hline & $\begin{array}{l}\text { Compartilhamento } \\
\text { de Interesses }\end{array}$ & $\begin{array}{l}\text { Quando os objetivos comuns unem diferentes instituições para a tomada de decisão; Quando instituições em rede } \\
\text { compartilham visões comuns proporcionam processos colaborativos na tomada de decisões; Quando os } \\
\text { interessados começam a reconhecer mutuamente as questões que os unem. }\end{array}$ \\
\hline & Liderança & $\begin{array}{l}\text { Quando lideranças pessoais ou institucionais estimulam o engajamento de atores não governamentais na tomada } \\
\text { de decisão de políticas públicas; Quando a liderança facilitadora reúne partes interessadas e as envolve na } \\
\text { colaboração; Quando há líder identificado em posição de ajudar a proteger recursos e apoio dentro de um } \\
\text { processo colaborativo. }\end{array}$ \\
\hline & Interdependência & $\begin{array}{l}\text { Quando crises culminam a necessidade de tomada de decisões que envolvam todos os afetados pelo problema em } \\
\text { questão; Quando os indivíduos e as organizações não são incapazes de realizar algo por conta própria, sendo esta } \\
\text { uma condição prévia para a ação colaborativa; Quando os participantes apreciam a interdependência que existe } \\
\text { entre eles. }\end{array}$ \\
\hline & Incerteza & Quando há incerteza coletiva sobre a forma de gerir os problemas da sociedade. \\
\hline \multirow{4}{*}{ 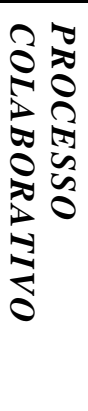 } & Diálogo & $\begin{array}{l}\text { Quando o diálogo direto é necessário para identificar necessidades, oportunidades e ganhos mútuos entre as partes } \\
\text { interessadas; Quando a deliberação é a comunicação fundamentada e amplamente celebrada como um marco e } \\
\text { ingrediente essencial de engajamento bem sucedido. }\end{array}$ \\
\hline & $\begin{array}{l}\text { Definição de } \\
\text { Objetivos }\end{array}$ & $\begin{array}{l}\text { Quando o processo se caracteriza pelos esforços contínuos para construir um sentido comum, articulando fins e } \\
\text { objetivos comuns; }\end{array}$ \\
\hline & $\begin{array}{c}\text { Compartilhamento } \\
\text { de Interesses }\end{array}$ & $\begin{array}{l}\text { Quando a descoberta refere-se à revelação dos interesses individuais, preocupações e valores compartilhados, bem } \\
\text { como a identificação e análise de informações relevantes e suas implicações; }\end{array}$ \\
\hline & $\begin{array}{l}\text { Protocolo da } \\
\text { Prática }\end{array}$ & $\begin{array}{l}\text { Quando há decisões processuais (por exemplo, definição de agendas, atribuição de um grupo de trabalho) e as } \\
\text { determinações substanciais (por exemplo, chegar a acordos sobre itens de ação ou recomendações finais); Quando } \\
\text { se abrange uma gama de protocolos de processos e estruturas organizacionais necessárias para gerenciar as }\end{array}$ \\
\hline
\end{tabular}




\begin{tabular}{c|l}
\hline & interações repetidas ao longo do tempo. \\
\hline Confiança Mútua & $\begin{array}{l}\text { Quando uma liderança pode trabalhar na dissolução de desavenças entre participantes, em favor de uma ação } \\
\text { conjunta; Quando é necessário conhecer o outro e provar um ao outro que são razoáveis, previsíveis e confiáveis. }\end{array}$ \\
\hline Compromisso & $\begin{array}{l}\text { Quando o compromisso com o processo significa desenvolver uma crença de que a boa fé negocial de ganhos } \\
\text { mútuos é a melhor maneira de obter os resultados desejados; Quando é permitido aos participantes atravessar as } \\
\text { fronteiras organizacionais, setoriais e / ou jurisdicionais que anteriormente separavam eles e comprometer -se a } \\
\text { um caminho compartilhado. }\end{array}$ \\
\hline Entendimento & $\begin{array}{l}\text { Quando há um acordo sobre uma definição do problema, ou sobre o conhecimento relevante necessário para } \\
\text { resolver um problema; Quando há a capacidade de compreender e respeitar as posições e os interesses dos outros, } \\
\text { mesmo quando não se concorda. }\end{array}$ \\
\hline Resultados & $\begin{array}{l}\text { Quando se reconhece uma situação "small wins" que pode alimentar o processo colaborativo, encorajando um } \\
\text { ciclo virtuoso de construção da confiança e compartilhamento da compreensão }\end{array}$ \\
\hline Liderança & $\begin{array}{l}\text { Quando se se reconhece alguém ou alguma instituição dotada de conhecimentos, habilidades e por vezes } \\
\text { experiência que orientam uma ação; }\end{array}$ \\
\hline Legitimidade & $\begin{array}{l}\text { Quando há a confirmação de que os participantes são confiáveis e críveis, com interesses compatíveis e } \\
\text { interdependentes, o que legitima e motiva a colaboração em curso. }\end{array}$
\end{tabular}

Fonte: Adaptado de Ansell e Gash (2007), Emerson, Nabatchi e Balogh (2011) e Selin e Chavez (1995) 


\subsection{Obstáculos à colaboração}

Alguns fatores contribuem com a ausência ou fraqueza das situações colaborativas entre sociedade e governo na gestão pública. Entre eles, a inabilidade das instituições para o processo colaborativo (FREEMAN, 1997; 2004; SYLVAN, 2008), a ausência de transparência das ações dos governos, a limitação das estruturas de oportunidades políticas geradas pelos gestores públicos, além dos processos de deformação institucional, acomodação e incorporação que ocorrem nas interações entre o Estado e o cidadão (NEWMAN e col., 2011). 


\section{METODOLOGIA}

O objetivo deste trabalho foi examinar a implementação e atuação da CIMEA- Suzano como um caso de governança colaborativa no provimento de políticas públicas de EA no município de Suzano no período 2009 - 2012. As estratégias de pesquisa adotadas foram a entrevista semi-estruturada e a análise documental, ambas pautadas pela metodologia de Análise de Conteúdo.

Uma entrevista semi-estruturada é uma estratégia de abordagem em que "é deixado ao entrevistado decidir-se pela forma de construir a resposta" (LAVILLE; DIONE, $1999^{13}$ apud MATTOS, 2005, p. 826). Esta estratégia, segundo Mattos (2005) é uma das bases de origem da "análise de conteúdo", cuja uma das mais importantes referências é Bardin (1977) ${ }^{14}$.

Santos F. (2012), em sua resenha sobre o trabalho de Bardin, enuncia a análise de conteúdo como uma descrição objetiva, sistemática e qualitativa do conteúdo extraído das comunicações e sua respectiva interpretação. Em adição, a autora destaca a análise documental como forma de condensação das informações, para consulta e armazenamento.

A técnica de análise de conteúdo se compõe de três etapas: a pré-análise caracterizada como uma fase de organização que utiliza alguns procedimentos como leitura flutuante, formulação de hipóteses e indicadores; a etapa de exploração do material para codificação a partir dos registros e a etapa de tratamento dos resultados e interpretação que se ocupa em categorizar os elementos segundo suas semelhanças e por diferenciação, com posterior reagrupamento, em função de características comuns. (CAREGNATO; MUTTI, 2006).

\subsection{Procedimentos de coleta de dados}

\subsubsection{Análise documental}

A fim de efetuar a fase de pré-análise através da leitura, foram reunidos além da legislação pertinente à política de EA, os materiais impressos e escritos provenientes da atividade da CIMEA-Suzano. Constitui este acervo as atas das reuniões, roteiros de trabalho, relatórios e textos específicos sobre a CIMEA-Suzano como artigos jornalísticos, artigos acadêmicos e uma publicação da Prefeitura Municipal de Suzano.

\footnotetext{
${ }^{13}$ LAVILLE, C.; DIONNE, J. A construção do saber: manual de metodologia da pesquisa em ciências humanas. Porto Alegre: Artes Médicas; Belo Horizonte: UFMG, 1999.

${ }^{14}$ BARDIN, L. Análise de conteúdo. Lisboa, Edições 70, 1977.
} 
Notas desta leitura foram tomadas e agrupadas e delas partiram a formulação da hipótese deste trabalho, construída com base nos indicadores de colaboração e participação construídos através da interpretação do ProNEA.

\subsubsection{Entrevista semi-estruturada}

Diversas categorias de instituições fizeram parte da CIMEA-Suzano no período 20092012. Participavam as secretarias municipais e organizações não governamentais, entre elas empresas, associações de amigos de bairro, associações de classe, universidades, organizações socioambientais entre outras categorias. Para compor o quadro de entrevistados foram selecionados os representantes das instituições com maior assiduidade nas reuniões e que assumiram posições de coordenação das atividades.

Do governo municipal selecionamos a bióloga e educadora ambiental Maria Henriqueta Andrade Raymundo, que como diretora de meio ambiente na gestão 2009 - 2012 foi a principal responsável pela articulação da política municipal de EA. Da sociedade civil selecionamos o gestor ambiental Fabio Ferreira, à época uma das lideranças da REAPs - Rede de Educadores Ambientais Populares de Suzano. Também da sociedade civil selecionamos a bióloga Nadja Soares, fundadora-presidente da Organização Bio-Bras. Do setor empresarial selecionamos Jefferson Correia, gerente de Relações Públicas da Kimberly-Clark.

As entrevistas com Henriqueta e Nadja foram realizadas pessoalmente, mas com Jefferson e Fabio foram realizadas por conferência virtual devido à localização destes. A duração média das entrevistas foi de 50 minutos e os registros foram realizados por meio de anotações das falas, que uma vez consolidadas e sistematizadas, foram expostas ao entrevistado para validação das informações.

Os temas relacionados na Tabela 4 (Descrição dos temas das intersecções), levantados através da revisão da literatura sobre governança colaborativa, formaram a base das entrevistas. Cada tema e sua descrição na literatura foram apresentados aos entrevistados para subsidiar o diálogo a respeito de determinada situação, permitindo assim, coletar os relatos das experiências e percepções destes.

Os relatos serviram à etapa de exploração do material, sendo codificados e posteriormente interpretados a partir da categorização das semelhanças e diferenças dos pontos discutidos e relatados. Mattos (2005) sugere a montagem de uma matriz de 
consolidação de dupla entrada das informações coletadas, em que uma entrada se apresenta as respostas e informações coletadas, em outra entrada as questões colocadas e na interseção as unidades textuais básicas de análise.

\subsubsection{Observação Participante}

Soma-se a esta análise a experiência particular desta pesquisadora de participação na CIMEA-Suzano enquanto integrante do Coletivo Educador VoS. O coletivo esteve envolvido no processo de formação da comissão, integrou os grupos de trabalho de construção do projeto político pedagógico da CIMEA-Suzano e da minuta da lei. Ao final de 2012, como integrante da Organização Bio-Bras esteve envolvida no desenvolvimento do Termo de Referência para o PMEA.

Todos os resultados obtidos através da análise de conteúdo das informações coletadas, foram codificados, categorizados e são descritos a seguir. 


\section{RESULTADOS E DISCUSSÃO}

Para a discussão dos resultados desta análise trazemos uma narrativa temporal da estruturação da CIMEA-Suzano, partindo da instituição da Secretaria de Meio Ambiente (SEMA) e perpassando pelo esboço de construção do SISMEA e da PMEA, para daí se alcançar a atividade da CIMEA-Suzano.

Com apoio da matriz de governança colaborativa, analisamos como pré-processo colaborativo todas as ações que foram realizadas até o momento da regulamentação da comissão por decreto, e como processo colaborativo, analisamos as atividades de desenvolvimento da lei municipal de EA e suas consultas públicas.

\subsection{O pré-processo colaborativo da CIMEA-Suzano}

O período 2009 - 2012 compreendeu o segundo mandato da gestão Marcelo Cândido no município de Suzano. Na continuidade do curso de mudanças na estrutura administrativa, o município através da Lei Municipal 4276/09 instituiu a criação da Secretaria Municipal de Meio Ambiente - SEMA e subordinado a ela, a Diretoria de Saneamento e Gestão Ambiental.

Dentre as competências atribuídas à Diretoria de Saneamento e Gestão Ambiental está a articulação da implementação do Sistema Municipal de Educação Ambiental (SISMEA) e da Política Municipal de Educação Ambiental (PMEA), estes apoiados em quatro eixos estruturantes, de atuação imbricada, não hierárquica e distinta em metodologia, porém conectados com o mesmo objetivo de consolidação da SISMEA e da PMEA.

Figura 5 - Eixos estruturantes da PMEA e SISMEA de Suzano

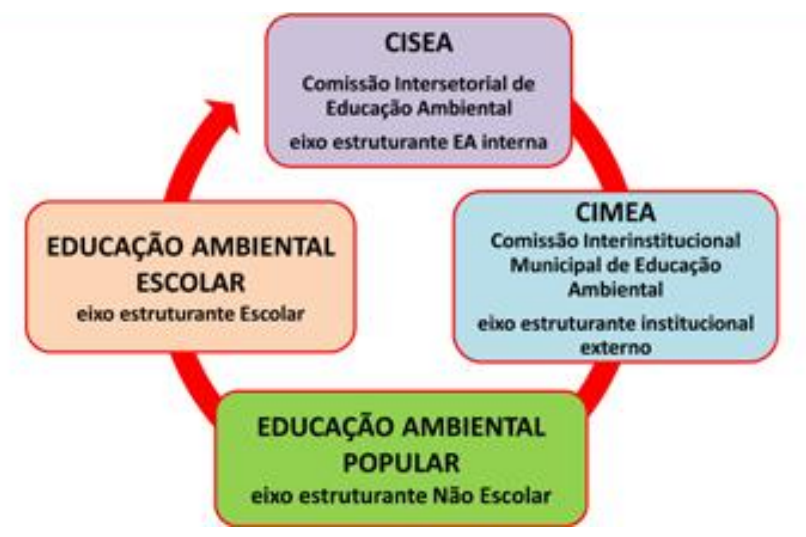

Fonte: Prefeitura Municipal de Suzano (2012, p. 15). 
A Comissão Intersetorial de Educação Ambiental - CISEA, alocada no eixo estruturante interno, constitui-se em um colegiado intrínseco à prefeitura municipal composto por representantes das secretarias municipais e pelo gabinete. Foi criada pelo Decreto Municipal 7925/10 como uma estratégia política para garantir o "processo de educação ambiental interno com a formação permanente e continuada deste colegiado em busca da transformação da Prefeitura de Suzano numa administração pública educada e educadora ambiental" (RAYMUNDO; SILVA, 2015, p. 41).

No eixo estruturante institucional externo está a Comissão Interinstitucional Municipal de Educação Ambiental - CIMEA, esta caracterizada como um "colegiado gestor deliberativo, formado por segmentos da sociedade civil, setor privado e poder público com atuação no município de Suzano e região, sendo representado por membros titulares e suplentes" (PREFEITURA MUNICIPAL DE SUZANO, 2012, p. 16). Antes de ser decretada como o locus de diálogo, reflexão, coordenação da própria PMEA e do SISMEA, a CIMEA se estruturou a partir de processos formativos e autoformativos de 80 horas/aulas sobre os diversos temas que transversam a EA.

Denominado como eixo estruturante não escolar, a Educação Ambiental Popular buscou "junto à população moradora, trabalhadora e estudantil de Suzano a identificação, mobilização, formação e fortalecimento de cidadãs e cidadãos aqui denominados como educadores ambientais populares" (RAYMUNDO; SILVA, 2015, p. 43). A consolidação deste eixo se deu através do Programa Municipal de Educação Ambiental, cujo objetivo era formar e capacitar grupos de educadores ambientais populares para atuarem na troca de seus saberes, interpretação e construção de novos conhecimentos.

O programa ofereceu oito cursos com carga de 80 horas/aula que foram realizados em oito regiões do município de Suzano: Palmeiras, Residencial Nova América, Jardim Colorado, Monte Cristo, Miguel Badra, Parque Maria Helena, Sertãozinho e Santa Rosa, e de acordo com Raymundo e Silva (2015), a distribuição geográfica dos cursos foi intencional, buscando desta forma capilarizar e descentralizar a EA em todo o território municipal. Os 250 educadores ambientais populares formados pelo curso deram origem à REAPs.

O eixo estruturante escolar denominado como Educação Ambiental Escolar teve como principal articulador a Secretaria Municipal de Educação. De acordo com Raymundo (2013, p. 426) o objetivo deste eixo foi pensado para: 
abranger os currículos da totalidade das escolas municipais, incluindo a dimensão socioambiental na gestão escolar que possa internalizar em seus projetos políticos pedagógicos as experiências diversificadas imbuídas das diferentes realidades e necessidades que a razão da gestão pública desconhece.

A articulação junto ao sistema municipal de ensino foi buscada em três frentes: a construção da PMEA inserida no Programa de Formação Continuada da Rede Municipal de Ensino, a estruturação nas escolas municipais de Com-Vidas (Comissões de Meio Ambiente e Qualidade de Vida) e a construção de Agenda 21 escolares.

Os quatro eixos estruturantes orientam-se pelos princípios, diretrizes e objetivos da PNEA e do ProNEA e, portanto, são coordenados por um Órgão Gestor (OG) composto pela Secretaria Municipal de Educação (SEC) e pela SEMA, tendo mais tarde seus objetivos expressos no artigo 16, parágrafo 1 , da lei 4614/12, sendo eles:

a) Coordenar, articular, propor diretrizes para a implementação e supervisionar a Política e o Sistema Municipal de Educação Ambiental, incentivando a capilaridade da Educação Ambiental, conforme sua competência regulamentar;

b) Coordenar a construção participativa e a implementação de um Programa Municipal de Educação Ambiental, garantindo a sua avaliação e revisão de forma democrática e periódica;

c) Participar do financiamento de programas, planos e projetos de Educação Ambiental, conforme regulamento e previsão orçamentária própria.

A referida lei que instituiu a PMEA e o SISMEA entre outras providências constitui fruto dos esforços realizados pelos eixos estruturantes sob coordenação do OG e articulação da CIMEA, pois, ainda que os quatro pilares estruturantes estivessem conectados pelo mesmo objetivo de consolidação da PMEA e do SISMEA, foi no pilar da CIMEA que os principais processos colaborativos se deram e culminaram no alcance dos objetivos propostos.

O fomento dado através da estrutura municipal à constituição e operação da CIMEASuzano pode ser aqui entendido como uma das forças que levam ao processo colaborativo, conforme destacaram Selin e Chavez (1995).

O passo de alavancamento da CIMEA-Suzano se deu por convites realizados pela SEMA às instituições do município de Suzano e da região do Alto Tietê, tendo como critério 
principal a diversificação de atores e setores. Seguindo os princípios do ProNEA, era imperativo haver uma ampla representatividade constituindo a comissão de construção da política municipal de EA, para assegurar a inclusão de diferentes pontos de vista.

Figura 6 - Reportagem sobre a formação da CIMEA-Suzano

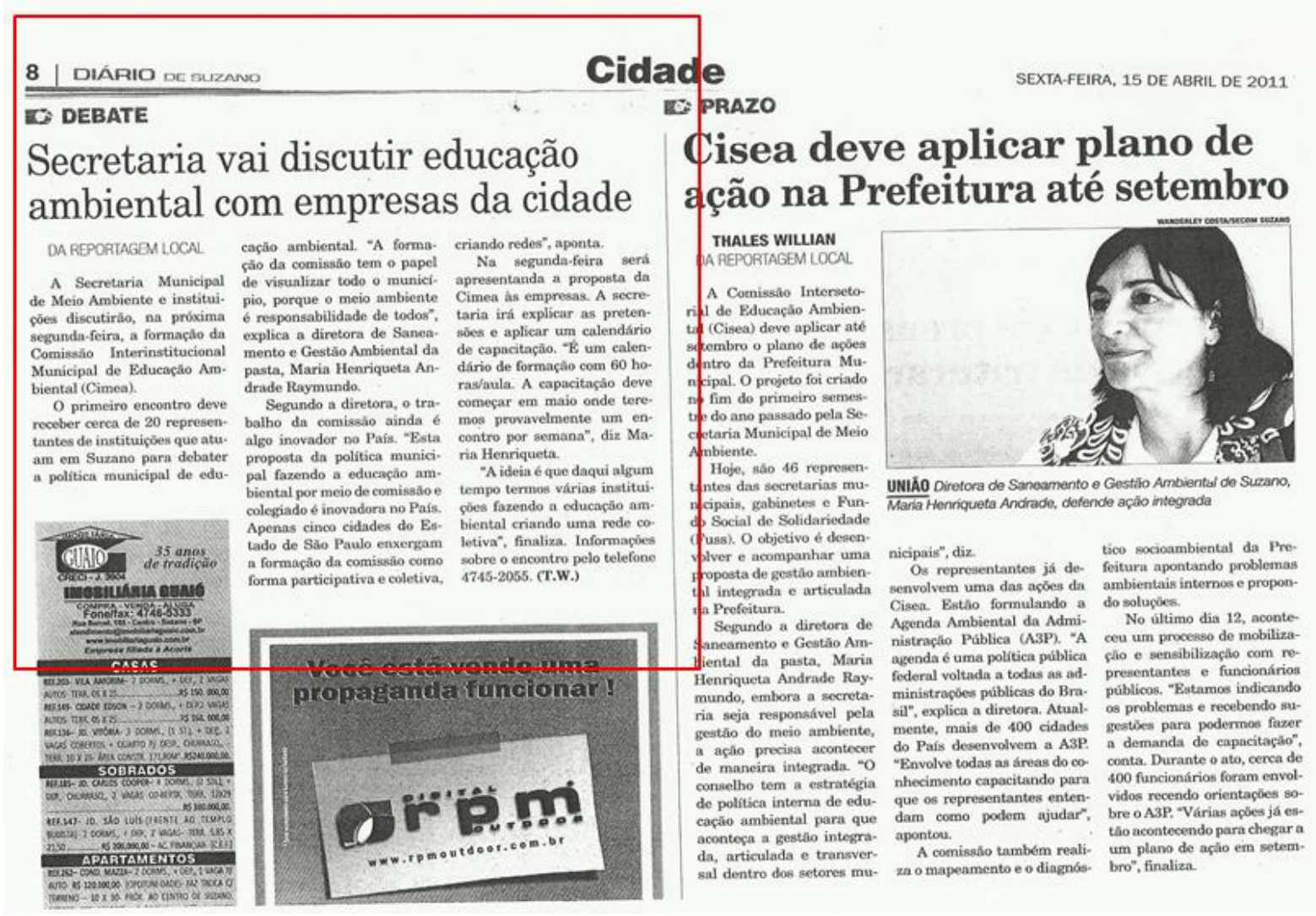

Fonte: Acervo SEMA/SISMEA

Desta forma, em atendimento ao convite da SEMA, integraram a CIMEA-Suzano empresas de diferentes ramos, negócios e tamanhos, organizações não governamentais formais e informais, movimentos sociais, sindicatos, universidades públicas e particulares, escolas técnicas, associações de classe, conselhos municipais entre outros. ${ }^{15}$

\footnotetext{
${ }^{15} \mathrm{O}$ Anexo I apresenta a lista das instituições membros da CIMEA-Suzano, seus representantes titulares e suplentes.
} 
Figura 7 - Reportagem sobre a adesão de 50 pessoas a CIMEA-Suzano

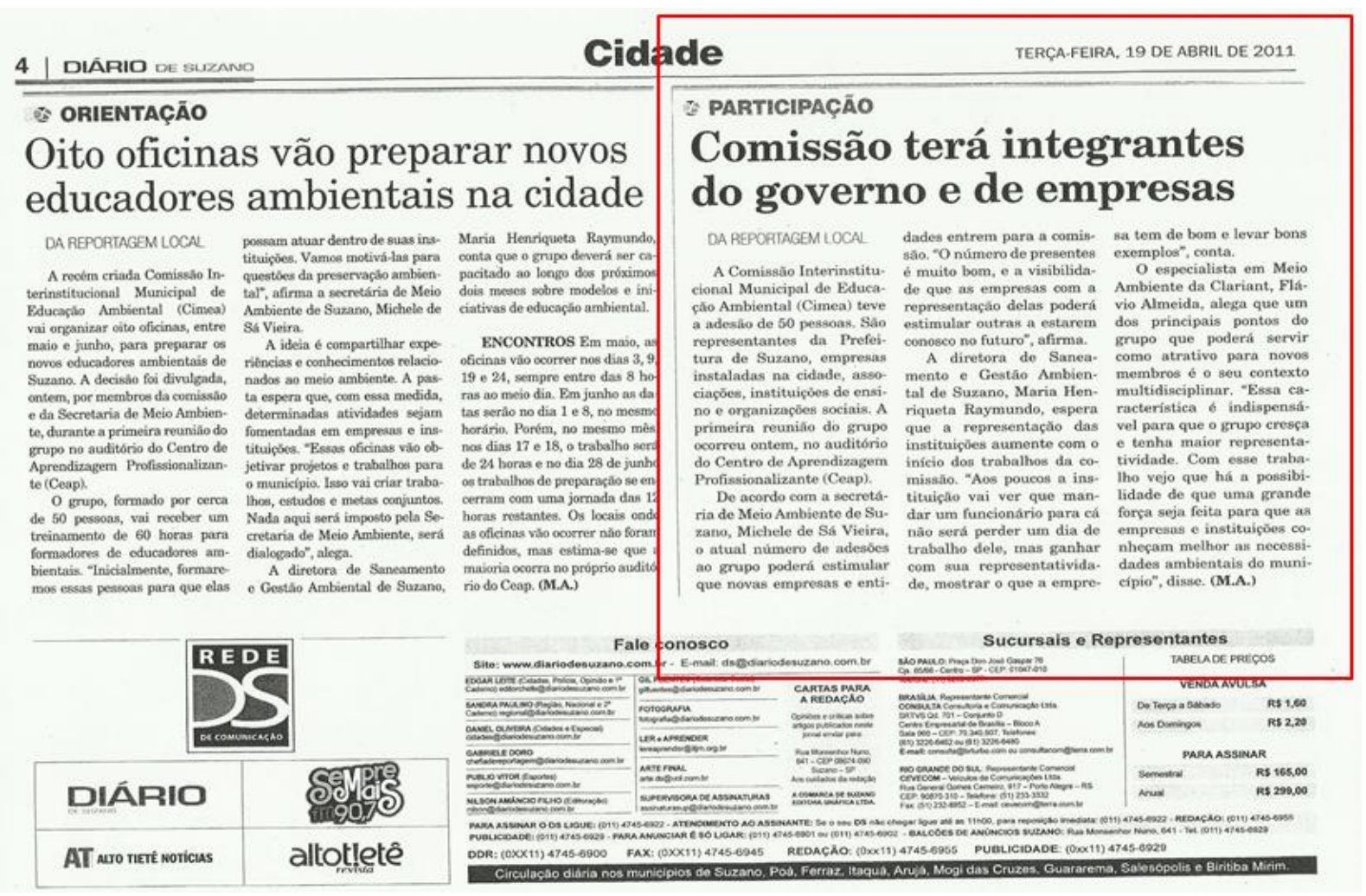

Fonte: Acervo SEMA/SISMEA

Todos os representantes das instituições foram envolvidos em um processo autoformativo iniciado em março de 2011, o qual teve 60 horas/aula realizadas entre os meses de março e junho do mesmo ano.

O processo de autoformação se deu pela divisão de quatro grupos de trabalho (GTs) onde os participantes se dedicaram à socialização de experiências institucionais, à elaboração de um cardápio de ofertas e demandas do grupo; à criação de instrumentos legais de institucionalização da própria comissão; à construção do projeto político-pedagógico (PPP), definição dos marcos conceitual, situacional e operacional, incluindo o reconhecimento do município.

Cada GT trabalhava ao mesmo tempo de forma autogerida e integrada e a sistematização das informações de cada grupo, e os resultados eram apresentados e dialogados em assembleia mensal. Deste processo formativo resultou o PPP, responsável pela definição do papel, da missão e das ações estratégicas da CIMEA-Suzano, o que conduziria as ações da comissão após sua institucionalização. 


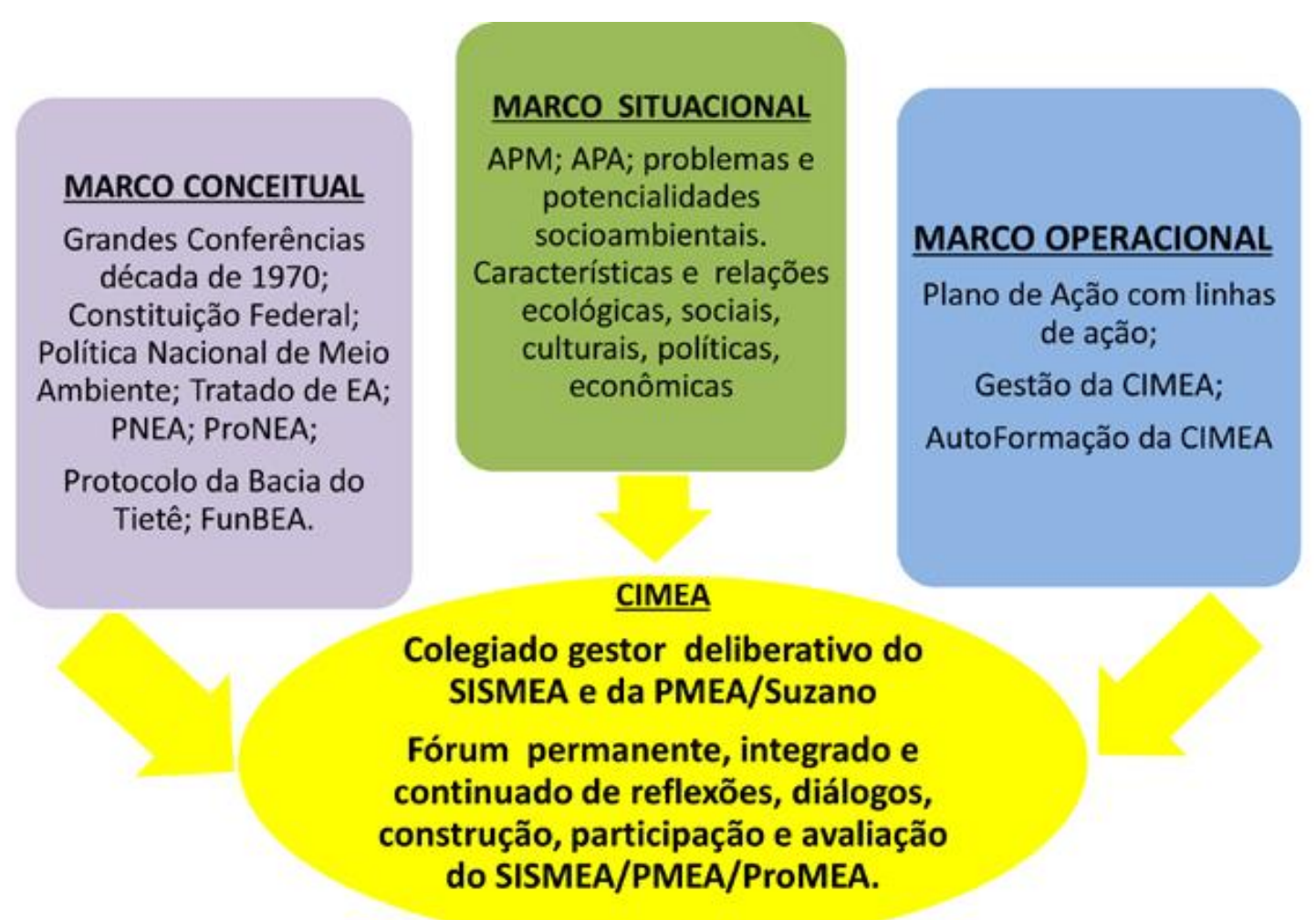

Fonte: Prefeitura Municipal de Suzano (2012, p. 53).

A diversidade de atores para uma maior representatividade, como dito, era objetivo, porém esta análise revelou dois importantes aspectos de assimetria de recursos entre as instituições. A assimetria entre as instituições envolve um desequilíbrio de poder que está relacionado à disponibilidade de recursos financeiros, humanos ou técnicos, e que influenciam a participação no processo colaborativo. Ansell e Gash (2007) apresentam dois exemplos importantes de assimetria: a inabilidade e inexperiência de algumas instituições de se envolver em discussões e a indisponibilidade de tempo, energia ou liberdade param se envolver em processos intensivos. Dentre as instituições que compunham a CIMEA-Suzano duas assimetrias foram destacadas, a técnica e a financeira.

A informação técnica primordial para participação na CIMEA-Suzano era o conhecimento básico sobre EA e sua relação com políticas públicas, sendo, portanto, igualmente primordial ter os conhecimentos básicos sobre política pública. Especificamente sobre EA, era importante entende-la como uma abordagem emancipatória em detrimento de uma abordagem exclusivamente conservadora, conforme distingue Jacobi (2005). Em sua diferenciação, a abordagem conservadora da EA está pautada por ações pontuais 
descontextualizadas dos temas geradores, frequentemente descoladas de uma proposta pedagógica e não questionadora do padrão civilizatório, enquanto a abordagem emancipatória se propõe a uma educação baseada em práticas, orientações e conteúdos que transcendem a preservação ambiental.

No conjunto de instituições participantes da CIMEA-Suzano, algumas instituições se destacavam pelo conhecimento dos referenciais teóricos que pautam o ProNEA e a PNEA, e consequentemente os objetivos da comissão, enquanto outras instituições, principalmente as empresas, demonstravam conhecimentos mais alinhados às questões relativas à sustentabilidade socioambiental empregada no meio empresarial. Outras instituições, precisamente aquelas sem nenhum vínculo direto com as questões ambientais, a desproporcionalidade de conhecimentos específicos sobre EA era maior. Quanto às informações sobre políticas públicas, o cenário de desproporcionalidade de conhecimento entre as instituições era superior ao de EA.

A disponibilidade de recursos financeiros que possibilitassem a participação das instituições também é um destaque de desproporcionalidade entre as instituições participantes da CIMEA-Suzano. Os representantes das empresas e também das secretarias municipais dispunham de mais recursos que possibilitavam a participação nas formações, como carros e honorários, enquanto os representantes de ONGs e movimentos sociais dispunham de recursos próprios para garantir a participação de suas instituições.

Ansell e Gash (2007, p. 551;552) argumentam que, "em uma situação de desequilíbrio de recursos entre as instituições participantes, para se obter um processo de governança colaborativa eficaz, é necessária uma estratégia positiva de empoderamento e representação dos grupos mais fracos ou desfavorecidos", contudo e felizmente, a governança colaborativa pode alavancar e mobilizar a capacidade de recursos entre os participantes (EMERSON; GERLAK, 2013). Esta visão também compartilhada por Emerson, Nabatchi e Balogh (2011) ao notarem que alguma assimetria pode ser positiva, levando os participantes a colaborarem na diminuição desta assimetria através da disponibilidade de financiamentos e subvenções.

A SEMA, em atenção a necessidade de garantir as participação das instituições na comissão, assim como prover recursos materiais e pedagógicos para o desenvolvimento das práticas, realizou uma parceria com a empresa Suzano de Papel e Celulose - uma das instituições participantes - além da cooperação técnica com o IBECC/UNESCO, e desta 
forma recursos financeiros e técnicos foram viabilizados para o processo formativo e autoformativo da comissão.

No conjunto diverso de instituições que integraram a CIMEA-Suzano, também eram diversos os objetivos e missões institucionais. Mesmo aquelas instituições sem formação legal como o caso da REAPs ou do Coletivo Educador VoS, detinham seus valores, missão e objetivos e implicitamente, tais valores ou mesmo a natureza de algumas instituições, eram antagônicas aos valores de outras instituições participantes, o que poderia causar conflitos e gerar a negação de participação de alguma instituição por discordância com a natureza ou com os valores, missões e objetivos de outras instituições.

A situação de antagonismo é claramente colocada por Ansell e Gash (2007) como um fator de insucesso para se iniciar um processo de colaboração, a menos que haja um elevado grau de interdependência entre as instituições ou haja a tomada de medidas para se corrigir os baixos níveis de confiança.

Entre as instituições participantes da comissão, embora os valores, missões e objetivos institucionais fossem conhecidos, estes não foram determinantes para tolher a participação na comissão. No caso da CIMEA-Suzano a um fator foi determinante para criar interpedendência entre elas: a aceitação pelas instituições de um objetivo comum, qual foi construir através de um processo colaborativo a política municipal de EA. Desta forma os valores, missões e objetivos institucionais foram colocados à parte da participação da CIMEA-Suzano e a permanência das instituições na comissão foi desligada das diferenças ideológicas.

Assim, a interdependência entre as instituições esteve ligada por um objetivo externo a elas, ou podendo-se afirmar secundário, pois, ainda que criar políticas de EA não seja o interesse principal das instituições, o desenvolvimento sustentável e a qualidade de vida socioambiental são em alguma medida objetivos de qualquer instituição na atualidade.

Selin e Chavez (1995) referem-se à interdependência entre instituições quando estas percebem que um problema só pode ser resolvido através de uma ação coletiva. O ProNEA em seus pressupostos sugere uma ação coletiva para a construção de políticas públicas de EA, sendo esta a mesma evocação da CIMEA-Suzano aos seus participantes.

Um destaque à participação das instituições está no engajamento destas nas ações, e tal engajamento foi reforçado por uma liderança advinda da própria administração pública. A 
liderança constitui ponto de relevância para o conjunto dos autores que subsidiaram a construção da matriz de governança colaborativa. Para Selin e Chavez (1995, p. 191) "a colaboração é, por vezes, defendida por um líder forte, cuja energia e visão mobiliza outros para participar", e para Ansell e Gash (2007, p. 554) "a liderança facilitadora é importante para reunir as partes interessadas e levá-las a empenhar-se num espírito de colaboração" e por fim, Emerson, Nabatchi e Balogh (2011, p. 09) referem-se à "identificação de um líder em condições de iniciar um processo colaborativo".

Instituída como diretora de Saneamento e Gestão Ambiental, a bióloga e educadora ambiental Maria Henriqueta Andrade Raymundo, com um histórico profissional junto ao governo federal e no estado da Bahia, trouxe ao município sua experiência com políticas públicas de EA e uma metodologia de trabalho fundada no ProNEA.

Para além das experiências profissionais há outro condicionante ligado ao perfil pessoal da diretora, que a tornou uma liderança personificada e, portanto, reconhecida por nome. Quanto à experiência que a credibilizou como liderança junto à CIMEA-Suzano e aos demais eixos da PMEA e do SISMEA, estão as metodologias de trabalho dialógico que permitiram o compartilhamento dos saberes, a capilarização dos conhecimentos e o empoderamento das instituições.

A metodologia dialógica empregada em todos os processos da CIMEA-Suzano partiu das convicções de uma prática histórica da EA, exercida pelos educadores ambientais e coordenadores do processo da política municipal, adotando-se como aspecto conceitualmetodológico os referenciais teóricos da EA crítica, cidadã e emancipatória, capaz de promover a cidadania a partir da autonomia dos sujeitos e transformação política libertadora (RAYMUNDO, 2013).

Foram adotadas as concepções de diálogo que permitem conhecer, reconhecer, integrar e
acolher a diversidade de saberes e caminhares, em processos individuais, coletivos,
institucionais, comunitários, públicos e privados a partir "círculos de diálogos" inspirados em
Brandão $(2002)^{16}$, no qual os diálogos iniciam-se internamente num processo individual de
autoconsciência, para deste seguir rumo ao diálogo com o outro, representando assim, dois
círculos de diálogos necessários para chegar num terceiro, que é o diálogo do coletivo, da
experiência da cidadania local à planetária (RAYMUNDO, 2013, p. 423)

Do ponto de vista do empoderamento das instituições, calcada no diálogo em construção, havia uma clareza acerca da política de oposição ao governo realizada pela

\footnotetext{
${ }^{16}$ BRANDÃO, C. R. A educação popular na escola cidadã. Rio de Janeiro : Vozes, 2002.
} 
Câmara de Vereadores do Município de Suzano dando como provável a desaprovação da política municipal de EA a ser desenvolvida pela CIMEA-Suzano. Esta conjuntura permitiu às instituições participantes avaliarem a interdependência existente entre elas e delas com a prefeitura, no sentido de fortalecimento que o conjunto de instituições daria ao projeto de lei.

Em outro e distinto cenário, o poder executivo poderia apresentar um projeto de lei desenhado pelo próprio punho, porém, apresentar à câmara de vereadores um documento forjado pela sociedade teria um peso absolutamente diferente para a avaliação dos vereadores. Portanto, ainda que pairasse sobre a comissão a incerteza da aprovação diante de um cenário político adverso inclusive à participação social, a CIMEA-Suzano se manteve engajada no processo formativo que a habilitaria ao desenvolvimento do projeto de lei.

A este cenário pode-se atribuir o vetor das incertezas colocadas por Emerson, Nabatchi e Balogh (2011), que tratam baseados em Bentrup (2001), das instituições que por si só poderiam resolver as questões colocadas e responder aos riscos relacionados, mas procuraram responde-los baseados na interdependência com outras instituições.

\subsection{O processo colaborativo da CIMEA-Suzano}

Após a conclusão do processo formativo, da elaboração do PPP e ser institucionalizada pelo Decreto Municipal 8068/11, e passou a orientar sua atividades autoformativas por duas frentes: Gestão e Autoformação.

A frente de Autoformação esteve especialmente envolvida com a socialização das experiências socioambientais das instituições participantes da comissão. Cada encontro da comissão era sediado em uma das instituições participantes e, integrava a pauta de discussão da reunião, a apresentação de algum programa ou ação socioambiental desenvolvido pela instituição sede. Esta prática possibilitava trocas de informações e conhecimentos entre as instituições, e por vezes, resultou em aconselhamentos e transações que propiciaram melhorias ou correções nos programas e ações apresentações.

Com o objetivo de coordenar a logística das reuniões (agendamento de locais, horários, transporte, alimentação etc) e de criar um canal de comunicação entre a comissão e a prefeitura municipal, fora instituída uma Secretaria Executiva composta por membros do OG e da empresa Kimberly-Clark. Os recursos financeiros do processo autoformativo da CIMEASuzano foram ampliados com o patrocínio da empresa Kimberly-Clark, com isso, registra-se 
apoio financeiro entre janeiro de 2010 e março de 2012, segundo o relatório de atividades da Secretaria Municipal de Meio Ambiente de Suzano (Anexo II).

Figura 9 - CIMEA-Suzano institucionalizada

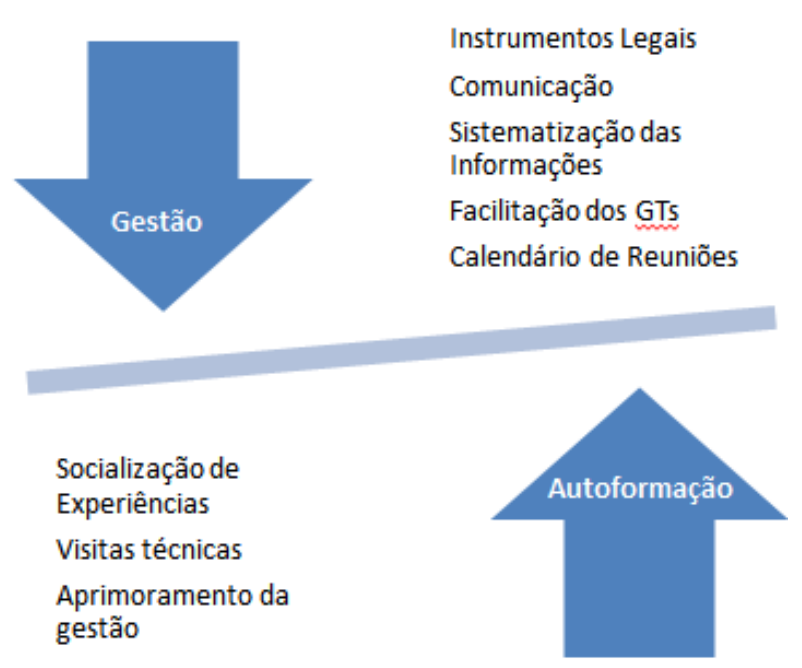

Fonte: Adaptado de Prefeitura Municipal de Suzano (2012, p. 62)

Já a frente de Gestão esteve principalmente envolvida com a formulação do texto da lei municipal de EA de regulamentação do SISMEA e da PMEA, e posteriormente a aprovação da política, envolvida com a formatação do Termo de Referência para constituição do Programa Municipal de EA (ProMEA).

Uma série de encontros foi promovida junto à sociedade susanense para cocriar, debater e fortalecer a construção da política. Uma mesa-redonda foi realizada para iniciar o debate com a população acerca dos temas de EA e políticas públicas. Com base nestas discussões preliminares, a comissão redigiu um texto que seguiu para consulta pública em dois momentos e situações distintas: uma análise prévia da Comissão de Política Urbana e Meio Ambiente da Câmara de Vereadores de Suzano, junto a CISEA e o colegiado da Secretaria Municipal de Educação; e depois o texto foi disponibilizado para consulta on line no site prefeitura, além de ser debatido em quatro encontros em diferentes regiões do município. 
Figura 10 - Convite mesa-redonda aberto à população

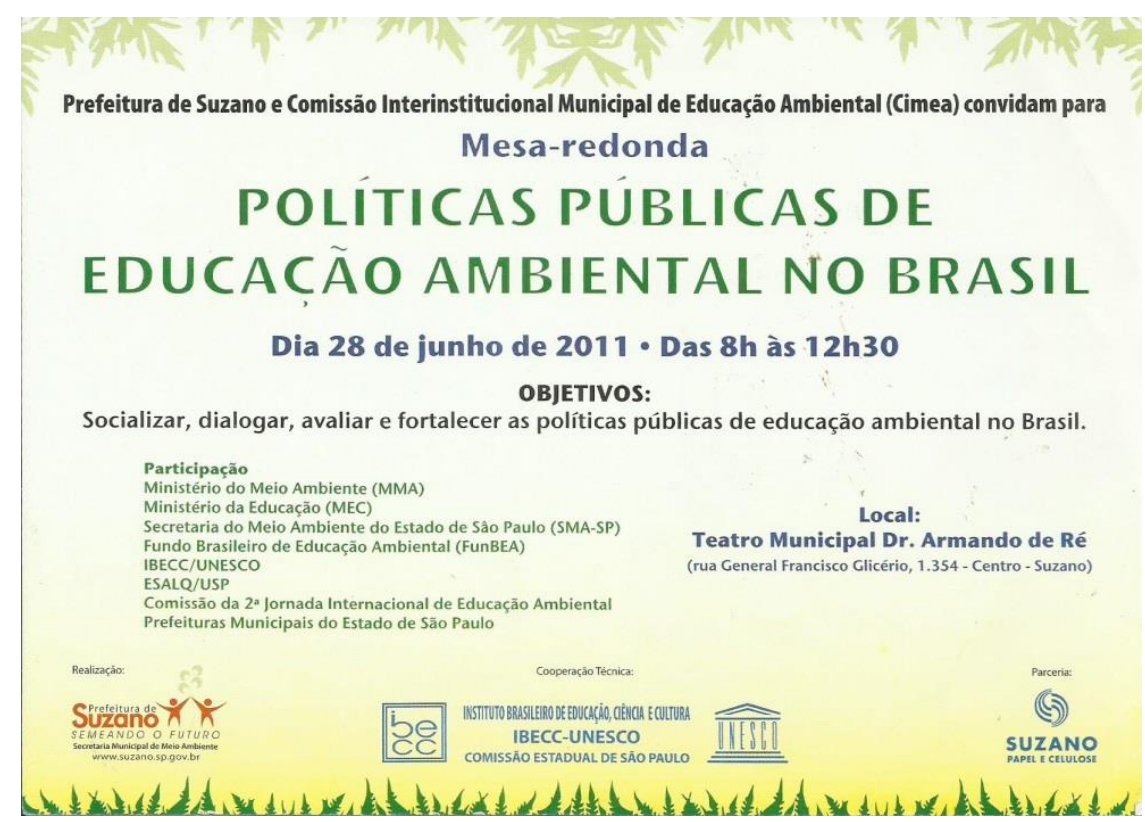

Figura 11 - Boletim da CIMEA convidando para a discussão da lei de EA

\section{Boletim da limea .: :}

\section{O que é a CIMEA?}

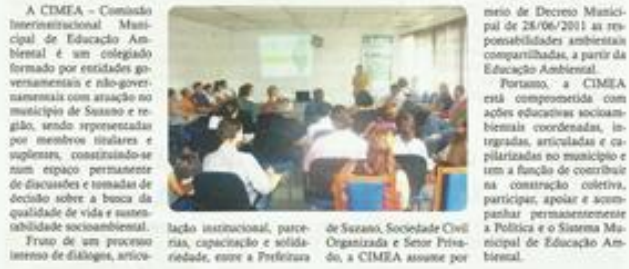

CIMEA vivencia um processo permanente e continuado de autoformação

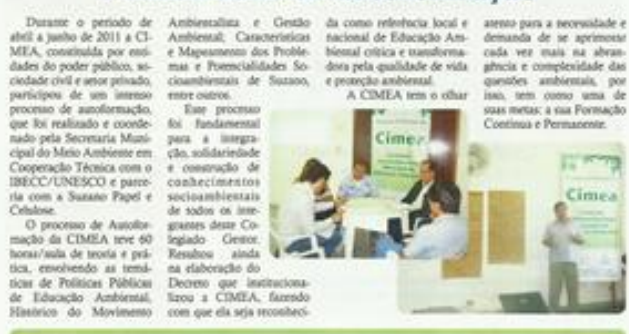

\section{Bolltind dinea}

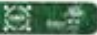

Processo de consulta pública para socialização e aprimoramento da Lei Municipal de Educação Ambiental

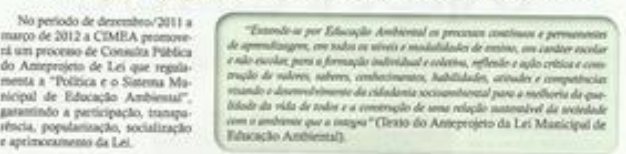

Fique por dentro, participe deste Processo de construção da Lei de Educação Ambiental!

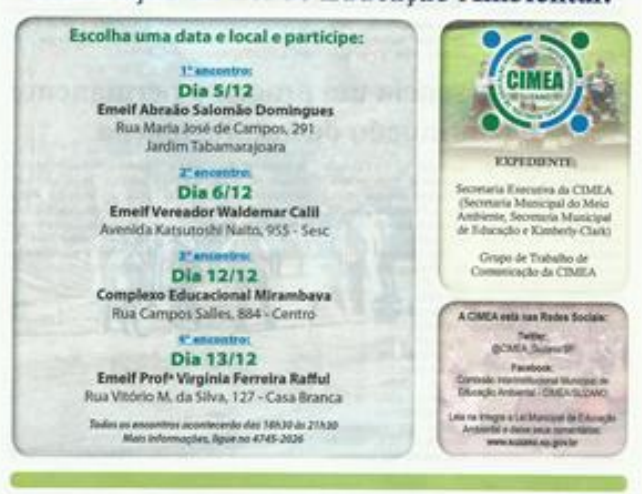

Fontes: Acervo SEMA/SISMEA 
Os quatro encontros envolveram cerca de 400 pessoas, entre elas professores a alunos das redes municipal e estadual de ensino, educadores ambientais populares de Suzano, técnicos especialistas em EA, gestores públicos municipais e população em geral ${ }^{17}$.

Os encontros coordenados pela CIMEA-Suzano exigiram um importante grau de colaboração entre as instituições, fator que depreende harmonização das diferentes formas de trabalho, dos diferentes graus de adesão organizacional e complexidade de relações (OORTMERSSEN; WOERKUM; AARTS, 2014). A ação coesa das instituições refletiu um cenário de confiança mútua, este muito provavelmente sedimentado pelo aspecto do diálogo intrínseco a todas as atividades desenvolvidas.

A metodologia dialógica, enquanto o protocolo da prática no pré-processo colaborativo da CIMEA-Suzano, também se fez protocolo no processo colaborativo, principalmente nos encontros de consulta da lei. Os mesmos passos de escuta e fala foram instalados, promovendo o que Ansell e Gash (2007, p. 558) definiram como o "processo de construção da confiança". Neste caso a confiança entre as próprias instituições da comissão e dela com a população.

Para além da ação coesa consta também a assiduidade das instituições nos compromissos firmados. Tanto nas reuniões regulares sediadas pelos membros, quanto nas reuniões extraordinárias como os encontros da consulta pública. O quórum de participação, assim como as atividades pós-reuniões que eram frequentemente assumidas pelos membros, denota o compromisso destas instituições com o processo em que estavam imersas. $\mathrm{O}$ compromisso é o que "possibilita os participantes a atravessar as fronteiras organizacionais, setoriais e / ou jurisdicionais que previamente os separavam, para comprometer-se a um caminho compartilhado" (EMERSON; NABATCHI; BALOGH, 2011, p. 14).

Embora comprometidas com o processo e coesas na realização das atividades, o entendimento acerca dos temas da EA e das políticas públicas por partes dos membros não foi satisfatório. O entendimento dos participantes de um processo colaborativo sobre o tema pelo qual estão imersos em colaboração, constitui um ponto importante, pois é relevante ter os conhecimentos necessários para se resolver as questões eminentes do processo (ANSELL; GASH, 2007).

\footnotetext{
${ }^{17}$ Anexo III
} 
Muitas instituições tiveram o primeiro contato com o tema da EA participando da CIMEA-Suzano, e mesmo dentre aquelas instituições com algum entendimento, as divergências de opiniões eram recorrentes, contudo, minimizadas pelo diálogo e pela exposição ao referencial teórico da EA.

O processo formativo também precisou recorrer algumas vezes às informações basais, pois algumas instituições trocaram seus representantes no curso das atividades da CIMEASuzano. Uma forma de minimizar a perda de informações sobre a trajetória de atividades da comissão foi a cada encontro realizar a exibição de todo histórico das atividades empreendidas.

A informação socioambiental, o conceito de EA e de políticas públicas constituem por si só resultados importantes para a trajetória individual de cada instituição participantes da CIMEA-Suzano, entretanto como resultado mais expressivo desta campanha de ações tem-se entrega do projeto de lei ${ }^{18}$ em 02 de julho de 2012 à Câmara de Vereadores de Suzano, que veio a aprovar a lei em 21 de novembro do mesmo ano.

Um novo sentimento de confiança coletiva foi estabelecido no grupo com a aprovação da lei, não se tratando de uma confiança entre os membros, mas uma confiança da ação conjunta que exerceram. Para Raymundo (2015, p. 44), a conquista da Lei Municipal 4614/12 é o "resultado de um caminhar participativo de comunidades de aprendizagem social, política e ecológica, instrumental e transformadora, sonhadora e realizadora da formulação e implementação de políticas públicas locais de educação ambiental”.

A força dos resultados leva o processo colaborativo a um movimento cíclico, gerando impactos e adaptações nas fases que tendem a se repetir (EMERSON; NABATCHI; BALOGH, 2011; SELIN; CHAVEZ, 1995). Entretanto, em 2013 teve início uma nova gestão municipal, menos afeita a processos participativos e que desmobilizou a atuação da CIMEASuzano, assim como dos demais eixos da PMEA e SISMEA.

Possivelmente esta desmobilização esteja associada à falta de uma liderança ligada à administração pública nesta nova administração, pois as instituições remanescentes da comissão não demonstraram força política para movimentar as engrenagens da prefeitura, e assim, renovarem o ciclo do processo colaborativo que já estiveram submetidos.

\footnotetext{
${ }^{18}$ Anexo IV
} 
Contudo, ocupando-se do período de análise proposto - o período de 2009 - 2012 cabe ressaltar a legitimidade das ações que resultaram na aprovação da lei municipal de EA dentro de um contexto colaborativo. A lei que instituiu o sistema e a política municipal de EA para a cidade de Suzano teve o envolvimento direto e participativo em torno de 400 pessoas entre participantes da CIMEA-Suzano e população. 


\section{CONSIDERAÇÕES FINAIS}

Os processos participativos em políticas públicas tornaram-se um campo de interesse para o socioambientalismo, pois, é também através de instrumentos políticos e de instituições públicas que se prolifera e fortalece as culturas de proteção do meio ambiente e de promoção da qualidade de vida. É com naturalidade, portanto, que se observa a EA tornar-se política pública.

Políticas de EA constituem um importante instrumento para governos e sociedades que buscam a sustentabilidade, porque, potencialmente, tanto podem ampliar a capacidade da sociedade em incidir sobre as políticas públicas, quanto podem gerar mudanças culturais profundas nos próprios gestores públicos. Como um sistema retroalimentado, sociedade e gestores públicos articulados por meio de suas instituições, promovem ações para a sustentabilidade calçadas no diálogo.

Os quatro eixos do SISMEA de Suzano constituem quatro vias de retroalimentação entre a sociedade e governo. Cada eixo se liga a um conjunto amplo de atores do município: os órgãos da administração pública direta no eixo CISEA, uma diversidade de órgãos e instituições no eixo CIMEA, a educação básica e fundamental no eixo Escolas e a comunidade geral no eixo Popular. Cada um destes atores são ao mesmo tempo transmissores e receptores de informações, e a partir deste fluxo se ligaram ao desenvolvimento de uma política pública municipal.

Dentre estes eixos coube à CIMEA a responsabilidade de estruturar para o município uma política de EA provida de recursos institucionais, financeiros e humanos e dotada de estratégias e metas. Isto porque o SISMEA era ainda um esboço de uma política e para que pudesse acessar recursos e ser perenizado para outras gestões, necessitava de regulamentação. Mas por que este papel coube à CIMEA e não para outro eixo?

Para se deflagrar um processo de desenvolvimento de uma política pública de EA à luz da PNEA, do ProNEA e do Tratado de Educação Ambiental para Sociedades Sustentáveis e Responsabilidade Global era imperativo envolver e articular a sociedade de tal forma que os diferentes pontos de vistas, valores, saberes, preferências e desafios pudessem ser conhecidos e abrangidos pelo diálogo. No conjunto dos eixos, a CIMEA e a EA Popular arrebanhavam a 
maior diversidade de atores, porém na CIMEA estava o grupo mais heterogêneo e de maior força política.

O eixo EA Popular detinha a participação do cidadão como sujeito morador, trabalhador e estudante do município, e apesar de uma amplitude de situações que pode revestir estes sujeitos, este pode ser considerado um grupo homogêneo - o grupo dos cidadãos. Ao passo que a CIMEA detinha a participação de instituições que representam classes e interesses dos cidadãos, inclusive associações de moradores, escolas e empresas. A força política destas instituições tem mais peso na barganha, na sustentação dos diálogos, na defesa dos interesses.

Contudo, a força política das instituições da CIMEA-Suzano se deu quando liderada por um agente específico, um gestor público conhecedor dos processos e provido de uma metodologia de trabalho provocadora e motivadora. No momento em que este agente deixou de atuar, a força política da CIMEA-Suzano foi enfraquecida.

Tal metodologia provocadora e motivadora era também experimentada pelo próprio governo federal, provedor da política e do programa nacional de EA. Destacada como uma metodologia calçada no diálogo, cujo referencial teórico abrange a pedagogia de Paulo Freire e a educação popular de Carlos Rodrigues Brandão.

A matriz de governança colaborativa desenvolvida a partir dos modelos serviu para desdobrar e conhecer os processos colaborativos empregados pela CIMEA-Suzano na construção da PMEA e do SISMEA. A opção pela matriz ao invés da escolha de um dos modelos para basear a análise sustenta-se pela possibilidade dada por ela de reunir os pontos de semelhança ou repetição existentes nos três modelos de governança colaborativos escolhidos. Desta forma pode-se realizar uma análise abrangente destes processos de uma forma mais rápida e contextualizada. Não foi objetivo desta pesquisa comparar os modelos, mas reconhecer os processos colaborativos na prática efetuada pela CIMEA.

Os modelos de governança colaborativa significam uma reunião de parâmetros para o reconhecimento de situações colaborativas entre sociedade e governo na gestão pública. Evidentemente, não são parâmetros conclusivos ou determinantes, mas antes, são parâmetros de entendimento de uma base importante para o surgimento e manutenção da colaboração. Desta forma, é possível inferir que à medida que o relacionamento entre sociedade e governo 
na tomada de decisões se distancia dos parâmetros colocados pelos modelos, menos se reconhece uma situação colaborativa entre eles.

Apesar dos pressupostos de colaboração estabelecidos pelos autores dos modelos, não há uma razão mínima definida que limite uma situação não colaborativa ou quase colaborativa. O que pode ser considerado positivo para uma argumentação de estímulo para a gestão pública se tonar colaborativa. Ao se observar processos e situações alinhadas aos pressupostos colocados, pode se considerar uma gestão que caminha para o sentido da colaboração. Enfatizando que os modelos se lançam para um circuito cíclico, onde as fases superadas impactam e adaptam as fases porvir. Da mesma forma, as políticas públicas a cada ciclo podem enriquecer seu caminho no sentido da colaboração.

No caso da CIMEA-Suzano alguns processos colaborativos observados merecem discussão. Este é o caso da Definição de Objetivos e do Compartilhamento de Interesses, que segundo os modelos se constituem em passos importantes para se conhecer os objetivos institucionais que levaram às instituições à participação na comissão, e como seus interesses foram compartilhados entre os demais participantes.

Ocorre que na CIMEA-Suzano o objetivo próprio dos participantes não foi colocado, mas sim dado a todos um objetivo único que era a construção da política, de forma que o compartilhamento dos interesses esteve subjugado a este objetivo comum. Neste caso a especificidade do tema da EA presente neste processo colaborativo molda o pressuposto do processo de governança colaborativa. Caso o tema fosse outra política concernente às instituições, por exemplo, resíduos sólidos, crimes ambientais, enfim, temas de relacionamento direto com as práxis ou possíveis intervenções nas instituições, seus objetivos próprios seriam colocados.

O tema da EA também interferiu nos pressupostos dos Conflitos pré-existentes e da Confiança mútua. Apesar da EA se dispor ao debate e incitar a participação pelo diálogo entre os diferentes pontos de vista, o objetivo de paz, solidariedade, sustentabilidade, melhoria da qualidade vida, entre outros bons objetivos moveu a participação das instituições. Quem se indisporia contra estes objetivos? Quem se indisporia contra aquele que, ao seu lado, defende estes objetivos? Possivelmente, no avançar do processo, no momento em que a CIMEASuzano se colocasse no diálogo com outras comissões, por exemplo, os conselhos de meio 
ambiente e educação alguns conflitos poderiam se iniciar e possivelmente influenciar os conflitos adormecidos ou silenciados.

Sobre a liderança exercida na CIMEA-Suzano é importante destacar mais alguns pontos. O governo municipal do período 2009 - 2012 se destacava pela abertura dada à participação popular, e neste período foram criados e fortalecidos vários conselhos, inclusive foi criada uma secretaria específica para coordenar a participação popular, portanto, era um momento oportuno para se criar uma comissão de EA. A liderança exercida na condução da SISMEA era também o exercício de um papel de gestora de uma política. Assim, gestora e liderança precisavam desempenhar na mesma pessoa os dois papéis, fato que não neutraliza o perfil de liderança e a experiência em EA e políticas públicas da diretora de gestão ambiental.

No que tange o pressuposto do Entendimento colocado pelos autores, é interessante perceber que não se trata de uma apropriação técnica ampla e delimitada para que se admita a participação. Era sim necessária uma compreensão básica para que se pudesse caminhar a partir dela. Conforme o pressuposto teórico, contudo é necessário garantir e incentivar que o entendimento seja nivelado e aumentado, o que de fato a CIMEA-Suzano se ocupou em realizar com o processo autoformativo. Entretanto, ao fim de 2012 e observado o enfraquecimento da comissão a partir de 2013, percebeu-se que a perenidade de processos autoformativos é importante para manter a articulação e ampliar o diálogo e os conhecimentos sobre determinado assunto, neste caso, os temas da EA e das políticas públicas.

Por fim, a conclusão deste trabalho permite vislumbrar a aproximação dos processos desenvolvidos pela CIMEA-Suzano com as diretrizes e os princípios postulados pelo ProNEA. A diretriz de Descentralização Espacial e Institucional é reconhecida na diversidade de espaços e suas respectivas instituições que se envolveram na atividade da comissão. A agenda de atividades e reuniões foi realizada nas sedes de muitas das instituições participantes da CIMEA-Suzano, ocasiões em que também estas instituições expunham ao grupo as ações socioambientais que desenvolviam internamente, sucedendo não apenas à informação, mas a troca de experiências.

Quanto à diretriz de Democracia e Participação Social, esta foi meticulosamente alinhada à metodologia fundamentada no diálogo, no sentimento de pertencimento de comunidade e na afirmação de identidade. Os círculos de diálogos, criados sob a perspectiva da pedagogia de Paulo Freire, consolidavam a reflexão entre pessoas, entre instituições, entre 
governos, entre pessoas e governos, entre instituições e governos etc. O diálogo se pronunciava pela dialética do falar - ouvir - falar - ouvir para daí deflagrar um pensamento coletivo de como resolver as questões e empreender as ações. Justamente nesta dialética empregada se dava o atendimento ao princípio do Enfoque humanista, histórico, crítico, político, democrático, participativo, inclusivo, dialógico, cooperativo e emancipatório. 


\section{REFERÊNCIAS BIBLIOGRÁFICAS}

AGRANOFF, R.; MCGUIRE, M. Collaborative Public Management: New Strategies for Local Governments. Washington, DC: Georgetown University Press, 2003.

AMORIM, S.; BOULLOSA, R. F. O estudo dos instrumentos de políticas públicas: uma agenda em aberto para experiências de migração de escala. Amazônia, Organizações e Sustentabilidade, v. 2, p. 59-69, 2013.

ANDRADE, D. F. e SORRENTINO, M. Aproximando educadores ambientais de políticas públicas. In: SORRENTINO, M. (Org.). Educação Ambiental e Políticas Públicas: conceitos, fundamentos e vivências. 1. ed. Curitiba : Appris, 2013. p. 2015 - 224.

ANSELL, C; GASH, A. Collaborative Governance in Theory and Practice. Journal of Public Administration Research, v. 18, p. 543-571, 2007.

BARDIN, L. Análise de conteúdo. Lisboa, Edições 70, 1977.

BARDOUILLE, N. C. The transformation of governance paradigms and modalities: insights into the marketisation of the public service in response to globalization. The Round Table, n. 353, p. 81-106, 2000.

BENTRUP, G. Evaluation of a Collaborative Model: A Case Study Analysis of Watershed Planning in the Intermountain West. Environmental Management, v. 27, p.739 - 748, 2001.

BEVIR, M. Democratic governance. New Jersey: Princeton, 2010.

BIASOLI, S.; SORRENTINO, M. Educação ambiental e municípios. In: RAYMUNDO, M. H. A.; BRIANEZI, T.; SORRENTINO, M. (Orgs.). Como construir políticas públicas de educação ambiental para sociedades sustentáveis? São Carlos : Editora Diagrama, 2015, p. 31-39.

BLACKMORE, C. Where do participatory approaches meet social learning systems in the context of environmental decision making? In: LANGEVEL, H.; ROLLINGS, N. (Ed.) Changing European farming system for a better future: new visions of rural areas. Netherlands: Wageningen Academic Publishers; 2006. p. 29 - 34.

BRANDÃO, C. R. A educação popular na escola cidadã. Rio de Janeiro : Vozes, 2002.

BRASIL. Constituição da República Federativa do Brasil. São Paulo: IMESP; 1988.

BRASIL. Órgão Gestor da Política Nacional de Educação Ambiental (PNEA). Comissões Estaduais Interinstitucionais de Educação Ambiental. Brasília, DF: PNEA, 2005. (Documentos, n. 1).

BRASIL. Órgão Gestor da Política Nacional de Educação Ambiental (PNEA). Portfólio do Órgão Gestor da Política Nacional de Educação Ambiental. Brasília, DF: PNEA, 2006. (Documentos, n. 7).

BRASIL. Educação Ambiental por um Brasil sustentável - ProNEA, marcos legais e normativos. Documentos de referência para o Fortalecimento da Política e do Programa Nacional de Educação Ambiental. Brasília, DF, 2014.

BRESSER-PEREIRA, L. C. A reforma da gestão pública na prática. In: Democracia e reforma da gestão pública: Construindo um Estado Republicano. Rio de Janeiro : Ed. FGV, 2009, p. 217 - 259. 
BORRINI-FEYERABEND, G. Collaborative management of protected areas: Tailoring the approach to the context. Gland : IUCN, 1996.

CAPELLA, A. C. N. Perspectivas Teóricas sobre o processo de formulação de políticas públicas. BIB, n. 61, p. 25-52, 2006.

CAPOBIANGO, R. P.; NASCIMENTO, A. L.; SILVA, E. A.; FARONI, W. Reformas administrativas no Brasil: uma abordagem teórica e crítica. REGE, v. 20, n. 1, p. 61-78, 2013.

CAREGNATO, R. C. A.; MUTTI, R. Pesquisa qualitativa: análise de discurso versus análise de conteúdo. Texto Contexto Enferm, v. 4, p. 679-684, 2006.

DENHARDT, J. V; DENHARDT, R. B. The new public service: serving, not steering. New York: M.E. Sharpe, 2003.

DINIZ E. Globalização, Reforma do Estado e Teoria Democrática Contemporânea. São Paulo em Perspectiva, v. 15, p. $13-22,2001$.

EMERSON, K.; GERLAK, A. K. Adpatation in collaborative governance regimes. Environmental Management, v. 54, p. 768 - 781, 2013.

EMERSON, K; NABATCHI, T; BALOGH, S. An Integrative Framework for Collaborative Governance. Journal of Public Administration Research, n. 22, p. 1 - 19, 2012.

FREEMAN, J. Collaborative Governance in the administrative state. UCLA Law Review, v. 1, p. 03 $-97,1997-1998$.

FREY K. Políticas Públicas: um debate conceitual e reflexões referentes à prática da análise de políticas públicas no Brasil. Planejamento e Políticas Públicas, v. 21, p. 211-259, 2000.

GRAY, B. Collaborating: Finding commom ground for multiparty problems. San Franciso : Jossey Bass, 1989.

HAJER, M. A; WAGENAAR, H (Ed.). Deliberative Policy Analysis. Cambridge: Cambridge University Press, 2003.

HEIDEMANN, F. G. Do sonho do progresso às políticas de desenvolvimento. In: HEIDEMANN, F. G.; SALM, J. F. (Orgs.). Políticas públicas e desenvolvimento: bases epistemológicas e modelos de análise. Brasília : Editora Universidade de Brasília, 2009, p. 23-39.

JACOBI, P. Educação Ambiental: o desafio da construção de um pensamento crítico, complexo e reflexivo. Educação e Pesquisa, v. 31, p. 233-250, 2005.

JACOBI, P.; TRISTÃO, M.; FRANCO, M. I. G. C. A função social da educação ambiental nas práticas colaborativas: participação e engajamento. Caderno Cedes, v. 29, p. 63-79, 2009.

Jagannath, H. P. To Collaborate or Not: That Is the Question. Public Administration Review, v. 73, p. 190-193, 2012.

JOHNSTON, E. W; HICKS, D; NAN, N; AUER, J. C. Managing the Inclusion Process in Collaborative Governance. Journal of Public Administration Research, v. 21, p. 699-721, 2010.

KISSLER, L; HEIDEMANN, F. G. Governança pública: novo modelo regulatório para as relações entre Estado, mercado e sociedade? RAP, v. 40, p. 479 - 499, 2006. 
LAVILLE, C.; DIONNE, J. A construção do saber: manual de metodologia da pesquisa em ciências humanas. Porto Alegre: Artes Médicas; Belo Horizonte: UFMG, 1999.

LASSWELL, H.D. Politics: Who Gets What, When, How. Cleveland, Meridian Books. 1936/1958.

LIMA J. A. Redes na Educação: questões políticas e conceptuais. Revista Portuguesa de Educação, v. 20, p. 151-181, 2007.

LUCA, A. Q. Uma análise do discurso da política pública federal de educação ambiental. São Paulo; 2013. [Doutorado - PROCAM/USP].

McDOUGALL, C. L; LEEUWIS, C; BHATTARAI, T; MAHARJAN. M. R; JIGGINS, J. Engaging women and the poor: adaptive collaborative governance of community forests in Nepal. Agric Human Values, v. 30, p. 569-585, 2013.

McGUIRE, M. Collaborative Public Management: Assessing What We Know and How We Know It. Public Administration Review, Special Issue, p. 33-43, 2006.

MORSE, R. S. Book Review: Investing in Democracy: Engaging Citizens in Collaborative Governance, 2011. Resenha de: SIRIANI, C. Investing in Democracy: Engaging Citizens in Collaborative Governance. Washington, DC: Brookings Institution Press, 2009.

NASCIMENTO M. F. F. Educação Ambiental: trajetórias, fundamento e práxis pedagógica. Cadernos IAT, v. 3, p. 104-117, 2010.

NEWMANN, J; BARNES, M; SUllivan, H; KNOPS, A. Public Participation and Collaborative Governance. Journal of Social Policy, v. 33, p. 203-223, 2004.

O'FLYN, J; WANNA, J. Collaborative governance: a new era of public policy in Australia? Canberra, Australia: ANU E Press, 2008.

OORTMERSSEN, L. A. van; WOERKUM, C. E. M. J. van; AARTS, N. The Visibility of Trust: Exploring the connection between trust and interaction in a Dutch collaborative governance boardroom. Public Management Review, v. 16, p. 666 - 685, 2014.

OSTROM, E. Understanding institutional diversity. Princeton, New Jersey: Princeton University Press, 2005.

PECCATIELlO, A. F. O. Políticas públicas ambientais no Brasil: da administração dos recursos naturais (1930) à criação do Sistema Nacional de Unidades de Conservação (2000). Desenvolvimento e Meio Ambiente, v. 24, p. 71-82, 2011.

PREFEITURA MUNICIPAL DE SUZANO. Educação Ambiental em Suzano: relato da construção da política e do sistema de educação ambiental do município. Suzano : 2012.

PROVAN, K. G; TENIS, P. Modes of Network Governance: Structure, Management, and Effectiveness. Journal of Public Administration Research, v. 18. p. 229 - 252, 2007.

PURDY, J. M. A Framework for Assessing Power in Collaborative Governance Processes. Public Administration Review, v. 72, p. 409-417, 2012.

RAQUEL, I. Governança Pública: A Consolidação de uma Matriz com Atributos que Caracterizam o Tema, na Perspectiva de Especialistas. Florianópolis: 2012. [Mestrado - UFSC]. 
RAYMUNDO, M. H. A. Política de educação ambiental de Suzano/SP: algumas dimensões para reflexão. In: SORRENTINO, M. (Org.). Educação Ambiental e políticas públicas: conceitos, fundamentos e vivências. Curitiba : Appris, 2013, p. 421 - 431.

RAYMUNDO, M. H. A; SILVA, L. F. Processo participativo de formulação de política pública municipal de educação ambiental. In: RAYMUNDO, M. H. A; BRIANEZI, T; SORRENTINO, M. Como construir políticas públicas de educação ambiental para sociedades sustentáveis? São Carlos : Diagrama Editorial, 2015, p. 40 - 47.

ROBERTSON, P. J; CHOI, T. Deliberation, Consensus, and Stakeholder Satisfaction: A simulation of collaborative governance. Public Management Review, v. 14, p. 83-103, 2012.

ROCHER, T. L. I; Polity, Politcs, Policy. El Pais, C. Valenciana, 09 mai. 2002. Disponível em: http://elpais.com/diario/2002/05/09/cvalenciana/1020971881_850215.html. Acesso em: 19 abr. 2014.

RONCONI, L. Governança pública: um desafio à democracia. Emancipação, v. 11, p. 21-34, 2011.

SANTOS, F. M. Análise de conteúdo: a visão de Laurence Bardin. Resenha de: [BARDIN, L. Análise de conteúdo. São Paulo: Edições 70, 2011, 229p.] Revista Eletrônica de Educação. São Carlos, SP: UFSCar, v.6, no. 1, p.383-387, mai. 2012. Disponível em http://www.reveduc.ufscar.br.

SANTOS, B. S. A crítica da governação neoliberal: O Fórum Social Mundial como política e legalidade cosmopolita subalterna. Revista Crítica de Ciências Sociais, p. 7-44, 2005.

SAUVÉ, L. Educação Ambiental: possibilidades e limitações. Educação e Pesquisa, v. 31, p. $317-$ $322,2005$.

SECCHI, L. Modelos organizacionais e reformas da administração pública. Revista de Administração Pública. Rio de Janeiro v.43. p. 347-369, 2009.

SERAFIM, M. P; DIAS, R. B. Análise de Política: uma revisão da literatura. Cadernos de Gestão Social, v. 3, p. 121-134, 2012.

SKELCHER, C; MATHUR, N; SMITH, M. The Public Governance of Collaborative Spaces: discourse, design and democracy. Public Administration, v. 83, p. 573-596, 2005.

SELIN, H. Global Environmental Governance and Regional Centers. Global Environmental Politics, v. 12, p. 18-37, 2012.

SELIN, S; CHAVEZ, D. Developing a Collaborative Model for Environmental Planning and Management. Environmental Management, v. 19, p. 189-195, 1995.

SYLVAN, L. Collaborative democracy: the citzen's ability to collaborate effectively. In: WANNA J.; O'FLYNN, J. Collaborative governance : a new era of public policy in Australia? Camberra : ANU E Press, 2008, p. 137 - 148.

SORRENTINO, M, TRAJBER, R, MENDONÇA, P, FERRARO-JUNIOR, L. A. Educação Ambiental como política pública. Educação e Pesquisa, v. 31, p. 285-299, 2005.

SOTERO, J. P. Financiamento Público da Política Nacional de Educação Ambiental. Brasília; 2008 [Mestrado - UNB].

SOUZA, C. Políticas Públicas uma revisão da literatura. Sociologias, a. 8, p. 20-46, 2006. 
WADDOCK, S. A. Understanding social partnerships: An evolutionary model of partnership organizations. Administration and Society, v. 21, p. 78-100, 1989. 


\section{ANEXOS}

\section{Anexo I - Plano de Ação da Comissão Intersetorial de Educação Ambiental - CISEA}

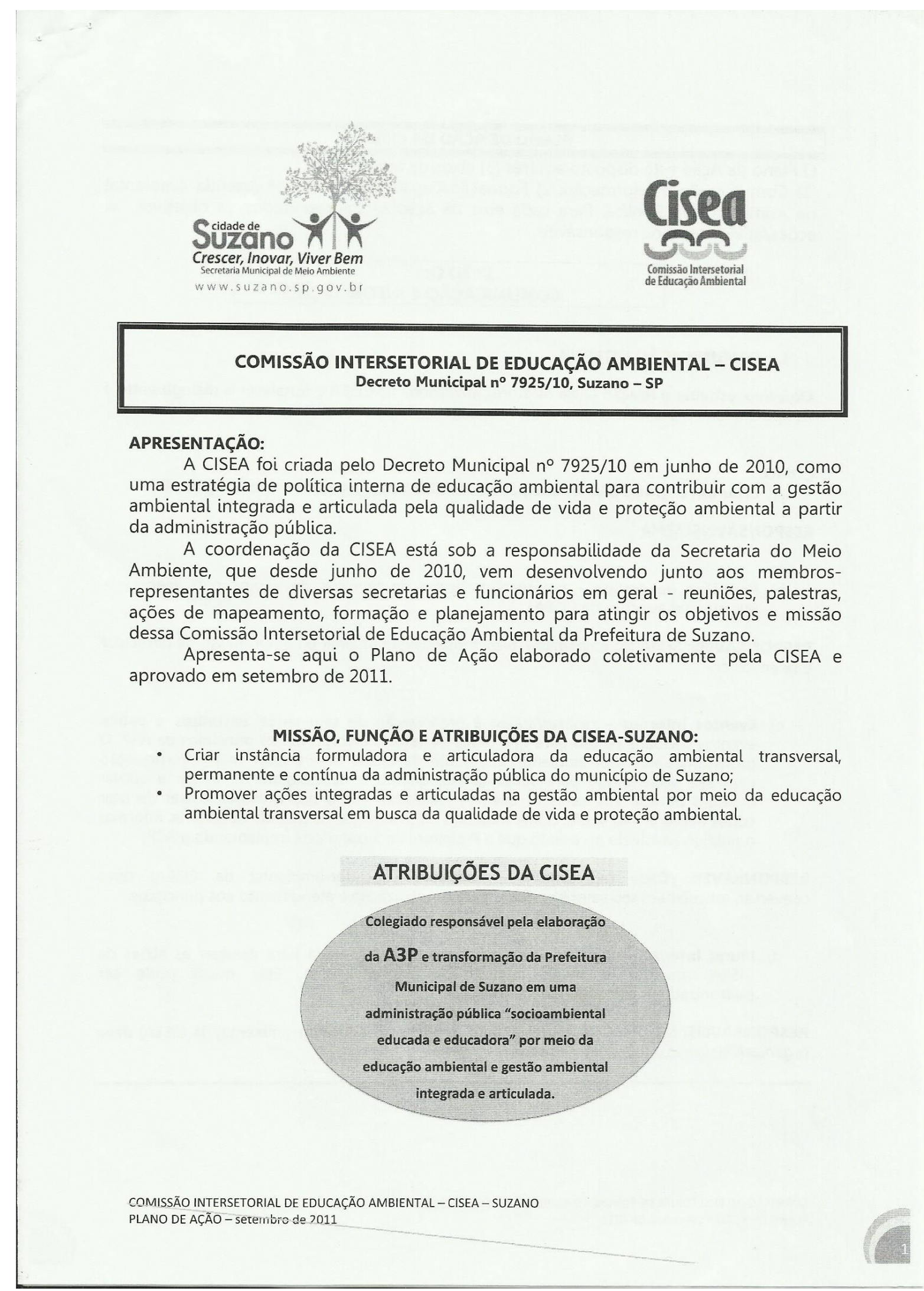




\section{PLANO DE AÇÃO DA CISEA:}

O Plano de Ação está disposto em três (3) eixos de ação:

1) Comunicação e Informação; 2) Formação/Capacitação e 3) A3P-Agenda Ambiental na Administração Pública. Para cada eixo de ação são apresentados os objetivos, as ações/atividades e os responsáveis.

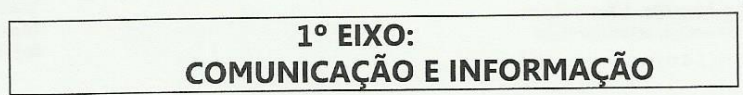

\section{COMUNICAÇÃO INTERNA}

Objetivo: estreitar a relação entre os atores envolvidos na CISEA e fortalecer o diálogo entre a equipe diretamente envolvida nos andamentos dessa Comissão.

сомо:

a) Criar um e-group para os integrantes da CISEA conversarem com mais agilidade;

\section{RESPONSÁVEIS: SEMA}

b) Reuniões de equipe - promover/participar de reuniões de equipe para planejar e encaminhar as ações da CISEA.

RESPONSÁVEIS: SEMA faz o chamado, mas, todos devem assumir o compromisso de participar e se envolver.

c) Eventos internos - realizar/apoiar a organização de seminários, encontros e outros eventos socioambientais para que todos os setores incorporem os princípios da A3P. O profissional-educador-ambiental integrante da CISEA deverá fazer reunião/articulação com seu secretário(a) para sensibilizá-lo, quanto a necessidade de incluir e adotar medidas da A3P em todos os eventos realizados, como por exemplo, deixar de usar copos descartáveis, confeccionar materiais de divulgação na medida necessária, informar o público envolvido no evento que a Prefeitura de Suzano está implantando a A3P.

RESPONSÁVEIS: Cada representante (profissional-educador-ambiental da CISEA) deve conversar, articular em seu setor/secretaria para sensibilização e atendimento aos princípios.

d) Mural Interno - criar um mural geral em cada Secretaria para divulgar as ações da CISEA, atualizar o mural mensalmente/quinzenalmente. Este mural pode ser padronizado, trazer a identidade da CISEA.

RESPONSÁVEIS: SECOM. Cada representante (profissional-educador-ambiental da CISEA) deve organizar, elaborar o mural em seu setor/secretaria. 


\section{COMUNICAÇÃO INSTITUCIONAL}

Objetivo: garantir a visibilidade da CISEA, contribuindo para o fortalecimento, credibilidade e legitimidade da sua existência perante a opinião pública.

\section{COMO:}

a) Criar um perfil/página no facebook, twitter - uma página com as informações sobre reuniões/ encontros/formações/resultados obtidos/etc (agendas, atos, fotos, vídeos e etc).

RESPONSÁVEIS: (SEMA) Vai criar. Todos devem alimentar, acompanhar, divulgar.

b) Criação da identidade (logomarca) da CISEA - para dar mais visibilidade interna e externa, fortalecimento, integração do grupo.

\section{RESPONSÁVEIS: SECOM /SEMA.}

c) Sugestões de Pauta- produzir sugestões de pauta para serem enviadas aos veículos de comunicação local, regional, a depender da abrangência do tema.

RESPONSÁVEIS: SECOM.

d) Suzano Agora - produzir informações sobre a CISEA para edições do Jornal Suzano Agora.

RESPONSÁVEIS: SECOM. E todos devem sugerir temas, assuntos.

\section{PRODUÇÃO E DISSEMINAÇÃO DE INFORMAÇÃO}

Objetivo: produzir informações que incentivem e apontem caminhos para a melhoria da qualidade de vida e proteção ambiental.

\section{COMO:}

a) Elaborar um "GIBI (folheto/folder)" para os funcionários e familiares - a SEMA, SME e SECOM, devem elaborar o conteúdo do gibi, para edições anuais com distribuição junto ao holerite. Envolver de alguma forma as escolas, além de todos sugerindo temas, assuntos e etc.

RESPONSÁVEIS: SECOM/SEMA/S.Educação.

b) Espaço Aberto - Produção de artigos que orientem, divulguem e socializem informações sobre a A3P, sobre meio ambiente de forma geral e ações da CISEA.

RESPONSÁVEIS: SECOM/SEMA e todos da CISEA devem sugerir temas, assuntos e também podem escrever para alguma edição. 


\section{SISTEMATIZAÇÃO, REGISTRO E ARQUIVO DE INFORMAÇÕES}

Objetivo: sistematizar, registrar e armazenar experiências, teorias, práticas, conceitos, informações e conhecimentos produzidos ao longo da existência da CISEA.

COMO:

a) Banco de Imagens - produzir um banco de imagens fotográficas e em vídeo para servir como memória e instrumento de divulgação da CISEA.

RESPONSÁVEIS: Todos devem enviar imagens/fotos das suas atividades relacionadas a CISEA feitas em suas secretarias/setores para a SECOM/SEMA produzirem o banco de imagens.

b) Relatórios - elaborar relatórios parciais e finais das ações da CISEA para socialização.

RESPONSÁVEIS: SEMA e Secretaria de Educação, organiza, sistematiza, finaliza. Todos devem enviar informações, dados, relatos para alimentar os relatórios.

c) Portfólio/Kit - preparação de um portfólio com informações e fotografias de divulgação da CISEA e suas açōes.

RESPONSÁVEIS: SECOM/SEMA/S. Educação. Toda CISEA deve contribuir.

\section{FORMAÇÃO / CAPACITAÇÃO}

Objetivo Geral: Mobilizar, nivelar e construir conhecimentos, democratizar informações, planejar as ações, integrar os colaboradores e os conhecimentos.

\section{I) CÍRCULOS DE APRENDIZAGEM}

COMO:

a) Fazer um GT - Capacitação dentro da CISEA para se encarregar da organização dos Círculos de Aprendizagem. Os círculos de aprendizagem podem ser palestras/seminários/rodas de conversa/cursos/oficinas/etc. O GT deverá fazer uma agenda para a realização dos Círculos de Aprendizagem sobre A3P, sustentabilidade ambiental, qualidade de vida, etc... (escolher os temas junto dos funcionários das secretarias). Definir os temas, palestrantes, horários e locais das palestras. Estes palestrantes podem ser pessoas da própria Prefeitura. Escolher um local central para reunir quantas pessoas puder participar (exemplos: Mirambava, Moricone, CEAP, etc), sendo que a cada circulo de aprendizagem o local deve mudar (rotatividade). Divulgar em diversos locais da Prefeitura e convidar por meio de $\mathrm{CI}$ própria da CISEA, além de folhetos e outros e outros materiais de divulgação.

RESPONSÁVEIS: SEMA, SME e SECOM. Toda a CISEA. 
II) ATIVIDADE EM CAMPO - FORMAC̣ÃO, CAPACITAÇÃO CONTINUADA DOS MEMBROS DA CISEA.

COMO:

a) A SEMA e a SME devem providenciar/organizar 2 vezes por ano, um Encontro de Formação da CISEA dentro da temática de educação ambiental e meio ambiente, com programação elaborada junto a CISEA, dentro dos moldes da formação em Itamonte-MG. Com período de até 3 dias de duração, em locais como Reservas Ambientais, Parques Naturais e outros lugares propícios para aprofundamento, concentração e interação do grupo.

RESPONSÁVEIS: SEMA/SECOM/S.Participação. Todos devem sugerir temas, assuntos.

III) CAMPANHA AMBIENTAL GERAL

a) DIA D = PELA QUALIDADE SOCIOAMBIENTAL - fazer paradas para "ação global", onde cada secretaria é mobilizada para assistir um vídeo, fazer uma oficina, assistir a uma palestra, recolhimento de pilhas, baterias, óleo,...; fazer exercícios de yoga, tai-chi, relaxamento... etc. Cada profissional-educador-ambiental integrante da CISEA pensa numa ação e juntos na CISEA elaboram o material de divulgação (a exemplo daquela ação realizada no dia 12/04).

RESPONSÁVEIS: Toda a CISEA

\section{A3P - AGENDA AMBIENTAL NA ADMINISTRAÇÃO PÚBLICA}

\section{Objetivos:}

Visa à sustentabilidade dos recursos naturais e a redução de gastos institucionais por meio do uso racional dos bens públicos e da gestão adequada dos resíduos, minimizando os impactos ambientais das suas ações.

\section{1) ARTICULAÇÃO, SENSIBILIZAC̣ÃO E DIÁLOGOS COM A SECRETARIA DE ADMINISTRAÇÃO}

\section{COMO:}

a) Formar um GT na CISEA para conversar/articular/sensibilizar as Secretarias de Administração/Planejamento/Jurídico sobre a importância de necessidade de inovar e modernizar a gestão pública com estes princípios da A3P;

b) Este GT deverá agendar reunião com o Secretario de Administração para apresentar a A3P e este plano de ação, para obter o apoio concreto;

c) Buscar exemplos de portarias e de processos de compras sustentáveis nas demais instituições públicas (nas 3 esferas de governo);

d) Contribuir para a elaboração das portarias/leis que insiram os critérios sustentáveis, quando possível, nas descrições de todas as compras ou contratações de serviços;

e) Substituir materiais de limpeza e de manutenção por outros sustentáveis (usar vassouras 
feitas com garrafa pet; utilizar materiais de limpeza biodegradáveis; utilizar papel toalha reciclado e de alta absorção; instalar, progressivamente, descargas econômicas nos banheiros);

f) Incentivar o uso de documentos digitalizados, bem como a leitura dos mesmos através das telas dos computadores, pelas portarias que determinam isto, pelas capacitações e sensibilizações.

RESPONSÁVEIS: Todos os itens acima estão sob a responsabilidade do GT formado por Secretaria de Governo, Ouvidoria, Secretaria de Obras e SEMA.

\section{II) ELIMINAR GRADATIVAMENTE O USO DE COPOS DESCARTÁVEIS}

\section{COMO:}

a) O profissional-educador-ambiental integrante da CISEA fará em seu setor, rodas de conversa, reuniões e outras atividades que desejar com o Secretário e todos os funcionários/servidores para sensibilizá-los sobre a importância de cada um adotar a sua caneca.

RESPONSÁVEIS: Todos. Cada um em sua secretaria/setor.

\section{III) FAZER BLOCOS DE RASCUNHO COM PAPÉIS A SEREM DESCARTADOS}

\section{COMO:}

a) O profissional-educador-ambiental integrante da CISEA fará em seu setor, rodas de conversa, reuniões com o Secretário e todos os funcionários/servidores para sensibilizá-los a fazer a separação adequada dos papeis que podem ser reutilizados em forma de blocos.

RESPONSÁVEIS: Todos. Cada um em sua secretaria/setor.

IV) INSTALAR COLETORES / ECOPONTOS (COPOS, PAPEL, PILHAS, BATERIAS, CARTUCHOS, MEDICAMENTOS, ÓLEO DE COZINHA) EM TODOS OS PRÓPRIOS PÚBLICOS

\section{COMO:}

a) Fazer parcerias: com a Organização Bio-Bras para a coleta do óleo de cozinha. Com a Suzaquim para as pilhas e baterias. Buscar parcerias para recolhimento dos cartuchos e medicamentos; e lâmpadas. Utilizar a parceria já existente com a Cooperativa de Catadores de Recicláveis para a entrega dos copos descartáveis e papel.

RESPONSÁVEIS: SEMA e S Saúde viabilizar e toda CISEA e demais secretarias executar .

b) O profissional-educador-ambiental integrante da CISEA fará em seu setor, rodas de conversa, reuniões e outras atividades que desejar com o Secretário e todos os funcionários/servidores para sensibilizá-los sobre a importância da coleta seletiva dos materiais indicados que deverão ir para o local próprio, indicado pela CISEA com as devidas orientações.

RESPONSÁVEIS: Todos. Cada um em sua secretaria/setor. 


\section{V) REALIZAR COLETA SELETIVA E ENVIAR PARA A COOPERATIVA (S) PARCEIRA DA} PREFEITURA DE SUZANO

\section{COMO:}

a) Fazer reunião com o setor de limpeza/administração para que após a separação dos materiais (armazenados em locais adequados- papeis, papelão, copos plásticos) a equipe de limpeza encaminhe os materiais para a Cooperativa parceira da Prefeitura.

b) O profissional-educador-ambiental integrante da CISEA deverá levar até a SEMA as pilhas, baterias, lâmpadas quando os seus ecopontos estiverem lotados, para que a SEMA se encarregue de encaminhar a SUZAQUIM.

c) O profissional-educador-ambiental integrante da CISEA deverá levar comunicar a Organização Bio-Bras quando os seus ecopontos de óleo de cozinha estiverem lotados, para que a Bio-Bras se encarregue de retirar.

RESPONSÁVEIS: Secretaria de Serviços Urbanos, SEMA. Cada um em sua secretaria/setor

\section{VI) CRIAR ANIMAÇÃO DA A3P PARA COLOCAR NA "PROTEÇÃO DE TELA" DE TODOS COMPUTADORES, AS QUAIS DEVEM SER ATUALIZADAS PERIODICAMENTE}

\section{COMO:}

a) Junto a SECOM elaborar arte da A3P, com alguma mensagem /frase para ser colocada nos computadores (proteção de tela);

RESPONSÁVEIS: SECOM e SEMA

b) Junto ao Setor de Informática/Secretaria de Administração instalar esta mensagem/arte feita pela SECOM em todos os computadores da Prefeitura;

RESPONSÁVEIS: Gabinete, SECOM e SEMA.

\section{VII) REALIZAR SINALIZAÇÃO DE INCENTIVO ÀS PRÁTICAS SUSTENTÁVEIS NOS MAIS} VARIADOS LOCAIS E EQUIPAMENTOS (ADESIVOS, ETC)

\section{COMO:}

a) Fazer reunião com SECOM para pensar em conjunto na sinalização sustentável.

b) Elaborar a arte e produzir adesivos com mensagens para: torneiras (uso racional de água); interruptores/tomadas/luz (apagar as luzes ao deixar o ambiente).

c) Cada profissional-educador-ambiental integrante da CISEA deverá se encarregar de colar os adesivos nos locais indicados do seu setor

RESPONSÁVEIS: SECOM/SEMA e Cada um em sua secretaria/setor. 
IX) REALIZAR UM MELHOR DIMENSIONAMENTO DOS MATERIAIS DE DIVULGAÇÃO/COMUNICAÇÃO, EVITANDO O DESPERDÍCIO POR CONTA DO EXCESSO NA TIRAGEM DESSES MATERIAIS.

\section{COMO:}

a) Dialogar com a SECOM para que a mesma adote estes princípios e faça a orientação a cada secretaria que solicitar os materiais de divulgação/comunicação. Repensar a tiragem do Suzano Agora, Agenda Cultural e outros.

RESPONSÁVEIS: SECOM, S. Cultura e cada um em sua secretaria/setor.

\section{CONSTRUÇÃO DA LEI QUE INSTITUCIONALIZA A POLÍTICA MUNICIPAL DE EDUCAÇÃO AMBIENTAL}

Para garantir a continuidade na execução, aprimoramento e fortalecimento da CISEA, que deve executar todo este plano de ação de forma permanente, é fundamental que seja elaborada a Lei Municipal de Educação Ambiental, trazendo a importância da capacitação contínua dos funcionários públicos para que os mesmos participem das ações internas pela qualidade de vida e proteção ambiental.

A Lei Municipal de Educação Ambiental é fundamental para que a CISEA continue existindo e o plano de ação seja executado de forma contínua, sempre sendo aprimorado e revisado.

Por isso, a CISEA participou ativamente, junto da CIMEA-Suzano (Comissão Interinstitucional Municipal de Educação Ambiental), do processo de elaboração da Minuta da Lei Municipal de Educação Ambiental durante o período de outubro/2011 a fevereiro/2012.

\section{* PARTICIPANTES DA CISEA:}

As Secretarias / Setores da Prefeitura Municipal de Suzano envolvidos e comprometidos na elaboração e aprovação deste Plano de Ação, até o presente momento são:

Secretaria do Meio Ambiente; Secretaria de Finanças; Secretaria de Segurança Alimentar Nutrição e Agricultura; Secretaria de Participação Descentralizada; Secretaria de Comunicação; Secretaria de Governo; Secretaria de Infraestrutura e Obras; Secretaria de Serviços Urbanos; Secretaria de Cultura; Secretaria de Transito; Secretaria de Saúde; Secretaria de Desenvolvimento Econômico e Turismo; Secretaria de Esportes; Ouvidoria; Secretaria de Defesa Social; Secretaria de Educação; Gabinete.

\section{Coordenação da CISEA}

Relatoria e sistematização:

Maria Henriqueta Andrade Raymundo (SEMA)

Suzano, setembro de 2011. 


\section{Anexo II - Relatório de Atividades do Órgão Gestor da PMEA e do SISMEA}

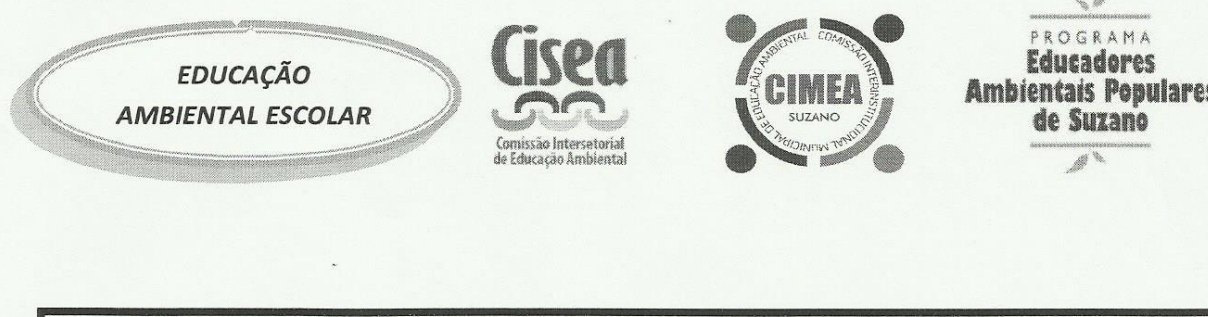

SISTEMA E POLITICA MUNICIPAL DE EDUCAÇÃO AMBIENTAL DE SUZANO - SP

A Secretaria Municipal do Meio Ambiente (SEMA) e a Secretaria Municipal de Educação (SEC) assumem a função de Órgão Gestor da Política Municipal Educação Ambiental de Suzano com a missão de elaborar e executar de forma compartilhada, participativa e transversal o Sistema Municipal de Educação Ambiental (SISMEA) a Política Municipal de Educação Ambiental (PMEA) e o Programa Municipal de Educação Ambiental (ProMEA).

O SISMEA e a PMEA-Suzano foram delineados e vem sendo implementados em consonância com as diretrizes da Política Nacional de Educação Ambiental - PNEA, Programa Nacional de Educação Ambiental - ProNEA, Política Estadual de Educação Ambiental, Tratado de Educação Ambiental para Sociedades Sustentáveis e Responsabilidade Global, além da histórica evolução e identidade crítica e popular da educação ambiental no Brasil e na América Latina.

Deflagrou-se a construção do Sistema, da Política e do Programa Municipal de Educação Ambiental, por meio de um processo participativo de aprendizagem socioambiental permanente e continuado, que envolve segmentos da sociedade civil, setor privado, poder público e a população, abrangendo a totalidade de regiões do município.

OBJETIVO GERAL

Promover Educação Ambiental permanente e continuada de forma conjunta, democrática, participativa, crítica e criativamente a partir de processos amplos estruturantes e integrados de aprendizagem socioambiental e emancipação de sujeitos, envolvendo o poder público, a sociedade organizada, o setor privado e a população abrangendo a totalidade de regiões do município em busca da transformação com justiça socioambiental e qualidade de vida.

\section{ESTRUTURAÇÃO E AÇÕES DO \\ SISTEMA E POLÍTICA MUNICIPAL DE EDUCAÇÃO AMBIENTAL}

A partir de 2009 o SISMEA e a PMEA foram delineadas e atualmente está́o consolidadas a partir de 4 eixos estruturantes, sendo que em cada um, varias estratégias foram implementadas para que a educação ambiental em Suzano seja permanente, contínua, articulada e capilarizada. Os 4 eixos estruturantes são:

a) CISEA- Comissão Intersetorial de Educação Ambiental da Prefeitura;

b) Programa de Educação Ambiental Popular;

c) CIMEA - Comissão Interinstitucional Municipal de Educação;

d) Educação Ambiental Escolar (Formal). 
A) CISEA- COMISSÃO INTERSETORIAL DE EDUCAÇÃO AMBIENTAL DA PREFEITURA

Eixo estruturante de educação ambiental interna, para fazer a gestão ambiental integrada e articulada. A CISEA é uma Comissão da Prefeitura, criada por decreto é composta por representantes, titulares e suplentes, de todos os setores. Com a missão de implementar a A3PAgenda Ambiental na Administração Pública, a CISEA representa um espaço de diálogos, reflexões, ações e tomadas de decisão para melhorar a qualidade de vida, proteção ambiental e sustentabilidade ambiental a partir da gestão pública.

\section{B) PROGRAMA EDUCAÇÃO AMBIENTAL POPULAR}

Este Programa Municipal é destinado a formar e capacitar cidadãos e cidadãs para atuarem com a troca de seus saberes, interpretação e construção de novos conhecimentos que sejam capazes de movimentar uma rede popular em parceria com o poder público na transformação dos problemas socioambientais.

O Programa deve ser permanente e contínuo, sendo desenvolvido a partir de cursos, oficinas, reuniões, credenciamento, entrega de materiais pedagógicos e pontos de apoio aos educadores ambientais populares formados.

Os educadores ambientais populares de Suzano estão atuando a partir deste Programa como multiplicadores e editores de conhecimentos e ações que visam contribuir para a qualidade de vida e sustentabilidade socioambiental e devem ser fortalecidos continuamente, bem como, novos devem ser formados.

\section{C) CIMEA - COMISSÃO INTERINSTITUCIONAL MUNICIPAL DE EDUCAÇÃO AMBIENTAL}

A Comissão Interinstitucional Municipal de Educação Ambiental - CIMEA é um colegiado gestor formado por segmentos da sociedade, setor privado e poder público com atuação no município de Suzano e região, sendo representadas por membros titulares e suplentes. Representa um espaço permanente de diálogos, reflexões, construções, produções e tomadas de decisão sobre a busca da qualidade de vida, justiça socioambiental e proteção do meio ambiente a partir da educação ambiental.

A CIMEA, comprometida com ações educativas socioambientais coordenadas, integradas, articuladas e capilarizadas no município, assumiu a função de contribuir na construção, participar, apoiar e acompanhar o Sistema, a Política e o Programa Municipal de Educação Ambiental.

\section{D) EDUCAÇ̃̃O AMBIENTAL ESCOLAR}

A construção da Política Municipal de Educação Ambiental foi inserida no Programa de Formação Continuada da Rede Municipal de Ensino.

A partir de diversas estratégias metodológicas como cursos, oficinas, encontros, reuniões, leituras de textos e outras, as escolas dialogaram, formaram-se e aprofundaram os seguintes eixos temáticos:

a) Tempo: o impacto das nossas ações para as gerações futuras;

b) Espaço: o território que ocupamos e como podemos trabalhar a realidade das diferentes regiões do município;

c) Água: elemento fundamental para Suzano e para sobrevivência da humanidade.

Busca-se a partir daí, estruturar Com Vidas (Comissões de Meio Ambiente e Qualidade de Vida) nas escolas, assim, como chegar a construção de Agendas 21 escolares, propiciando espaços permanentes de diálogos, reflexões, construção e produção de conhecimentos que transformem as situações indesejadas. 
RESUMO DAS ATIVIDADES COM RESULTADOS QUANTITATIVOS E QUALITATIVOS Maio de $\mathbf{2 0 0 9}$ a outubro de 2012:

$>8$ Cursos de Educação Ambiental Popular de 80horas/aulas de teoria e prática cada um. Os cursos foram realizados nas regiões de Palmeiras, Colorado, Jardim Nova América, Monte Cristo, Miguel Badra, Parque Maria Helena, Sertãozinho e Santa Rosa - Aproximadamente 250 Educadores Ambientais Populares formados;

> 13 Oficinas Locais da II Jornada Internacional de Educação Ambiental - Tratado de Educação Ambiental para Sociedade Sustentáveis e Responsabilidade Global, com 4 horas/aula cada Oficina, envolvendo os educadores ambientais populares de cada turma, além dos gestores públicos da Prefeitura de Suzano e outros. Participação de cerca de 200 pessoas;

$>$ Cerca de 50 Intervenções socioambientais realizadas pelos Educadores Ambientais Populares com orientação e apoio da Secretaria de Meio Ambiente;

$>1$ Feirão Socioambiental de 8 horas de atividades com a realização de oficinas, palestras, vídeos, trilhas, teatros, apresentação de músicas, sorteios de visitas a Unidade de Conservação e entrega de livros, envolvendo cerca de 500 pessoas da população em geral;

$>$ Aproximadamente 50 Instituições, da sociedade civil e setor privado, mobilizadas e envolvidas na busca conjunta pela qualidade de vida e sustentabilidade;

> Capacitação em Educação Ambiental de 60horas/aula para 30 instituições do setor privado, sociedade civil e poder público para a formação da CIMEA;

$>$ Mesa redonda sobre Políticas Públicas de Educação Ambiental no Brasil com a participação de cerca de 400 pessoas de Suzano e mais de 15 municípios do estado de SP;

$>$ Funcionários Públicos Municipais mobilizados e sensibilizados para a redução dos gastos públicos a partir da racionalização dos recursos naturais e consumo consciente dentro da Administração Pública por meio de:

- Elaboração e publicação de 11 textos/artigos para o Espaço Aberto - jornal interno da Prefeitura de Suzano com tiragem de 4000 exemplares;

- Questionários aplicados para cerca de 200 funcionários/mapeamento socioambiental interno;

- Oficina de 24horas/aula para a CISEA- Comissão Intersetorial de Educação Ambiental da Prefeitura de Suzano;

- Oficinas e reuniões da A3P com cerca de 500 funcionários envolvidos.

2 Oficinas de Comunicação Comunitária para o Desenvolvimento Sustentável Local em parceria com a Secretaria de Comunicação-SECOM, com 20horas/aula cada uma para cerca de 50 pessoas;

$>$ Cerca de 500 pessoas envolvidas/participantes no Processo de Consulta Pública do Anteprojeto da Lei de Educação Ambiental no período de outubro/2011 a fevereiro/2012 coordenado pela CIMEA; 
2 Cursos de Aprofundamento Curricular de Introdução a Educação Ambiental para Professores da rede Municipal de Ensino com 32 horas, ao término os professores participaram da oficina de aprofundamento confeccionando exposição de trabalhos e idealização da Sala Verde;

$>2$ Cursos de Aprofundamento Curricular "Paisagem, Trabalho e Memória" correlato com o curso de Introdução a Educação Ambiental, ao término os professores participaram de oficina de aprofundamento com a construção de portfólio sobre Suzano;

> 4 Paradas Pedagógicas com formações sobre os eixos: tempo, espaço e água, abordando a Escola-comunidade-território, para mais de 3.000 profissionais da Educação;

$>$ Criação do "Espaço Sala Verde" no Complexo Educacional Mirambava, fortalecendo e formando Educadores e Educadoras da Região do Alto Tietê nos debates acerca do tema socioambiental, por meio de cursos, palestras, reuniões, biblioteca ambiental e outros;

> Publicação de material impresso sobre Meio Ambiente e Educação Ambiental destinado a toda Rede Municipal de Ensino;

> 250 Mochilas do "Educador Ambiental Popular" distribuídas para Educadores Ambientais Populares, CIMEA e CISEA;

> Apresentação da Política Municipal de Educação Ambiental de Suzano no Seminário Estadual sobre a Regulamentação da Política de Educação Ambiental de SP, para cerca de 200 pessoas do poder público municipal, estadual, federal; sociedade civil e setor privado;

$>1$ Encontro de Educadores Ambientais Populares - Conexão do Local com o Global - VII Fórum Brasileiro de Educação Ambiental e Rio+20, com 20 horas/aula e envolvimento de cerca de 300 pessoas;

$>$ Coordenação do Encontro Regional do Alto Tietê Cabeceiras de Regulamentação da Política Estadual de Educação Ambiental, com 4 horas de atividades envolvendo cerca de 50 pessoas de toda região;

D Participação e representação de 4 professoras da rede Municipal de Ensino e 4 Educadores Ambientais Populares no VII Fórum Brasileiro de Educação Ambiental - Salvador -BA;

> Apresentação da Política Municipal de Educação Ambiental de Suzano em mesa-redonda durante o VII Fórum Brasileiro de Educação Ambiental para cerca de 600 pessoas;

> Apresentação de painel sobre a Política Municipal de Educação Ambiental no VII Fórum Brasileiro de Educação Ambiental - Salvador -BA;

> Oficina Suzano Conexão - VII Fórum Brasileiro de Educação Ambiental-Rio+20 com 8 horas/aula e ferramentas de educação à distância, realizado em Suzano-SP paralelamente ao evento do VII Fórum, envolvendo cerca de 70 pessoas; 
$>$ Programação Socioambiental com a realização de mini-curso, palestras, oficinas e distribuição de livros socioambientais no Salão Internacional do Livro junto a Secretaria de Educação envolvendo cerca de 500 pessoas no período de 13 a 22 de abril de 2012;

$>$ Caravana dos Povos - Suzano+20, a Rio+20 começa Aqui, atividade preparatória para a Rio+20, envolvendo cerca de 100 pessoas;

> Jornada Local de Educação Ambiental rumo a Cúpula dos Povos na Ri0+20, para a apresentação dos resultados na Rio+20, com 4horas/aula envolvendo cerca de 50 pessoas;

> 1 Curso de Meio Ambiente e a Prática Profissional realizado pela CISEA, sob a coordenação da Secretaria de Meio Ambiente para 30 funcionários públicos com 16 horas/aula;

> 1 Curso de Tecnologias de Educação a Distância para a Rede de Educadores Ambientais Populares, com 20 horas/aula e a entrega do site para uso livre dessa Rede de educadores, envolvendo 20 pessoas;

$>$ Instalação de 15 ecopostos de óleo de cozinha nos próprios públicos, por meio de parceria com a Organização Bio-Bras;

$>$ Plantio de cerca de 500 mudas de espécies nativas da Mata Atlântica no município a partir da educação ambiental;

$>$ Criação do site plataforma Moodle para arquivo histórico, estudos, trocas e aprendizagem socioambiental a partir da Política Municipal de Educação Ambiental - Suzano entregue para o uso e facilitação pela REAPS-Rede de Educadores Ambientais Populares de Suzano;

$>$ Realização da Oficina de Formação e Planejamento para a CIMEA-Suzano com 24 horas de atividades em Itamonte-MG com a participação de 18 instituições;

$>$ Cerca de 20.000 pessoas da população em geral mobilizadas e sensibilizadas para as questões socioambientais (indiretamente);

> Apresentação da Política Municipal de Educação Ambiental de Suzano em mesa redonda e seminários distintos para os municípios paulistas de Bertioga, Praia Grande, São Vicente, Santos, Itu, Mogi das Cruzes, Americana, Piracicaba, São José dos Campos, São Paulo e Vitória-ES, envolvendo no total cerca de 1.000 pessoas. 


\section{RESULTADOS QUALITATIVOS:}

* Visibilidade regional, estadual e nacional do Município de Suzano;

* Formação dos Educadores Ambientais Populares e a criação da Rede de Educação Ambiental Popular de Suzano- REAPS;

* Pessoas da população envolvidas e engajadas nos processos de busca da melhoria da qualidade de vida e sustentabilidade ambiental;

* Instituição das Secretarias Municipais do Meio Ambiente e Educação como Órgão Gestor da Política Municipal de Educação Ambiental;

* Instituição oficial da CISEA e CIMEA por Decreto Municipal;

4. Fortalecimento dos laços de identidade territorial e das capacidades humanas;

* Estabelecimento de alianças entre os atores sociais e o poder público, pactuando e assumindo responsabilidades compartilhadas, parcerias e atuação solidária;

* Elaboração coletiva do Plano de Ação da Agenda Ambiental da Administração Pública (A3P) da Prefeitura Municipal de Suzano, coordenado pela CISEA;

- Consulta Pública do Anteprojeto da Minuta da Lei que instituí a Política e o Sistema Municipal de Educação Ambiental, organizado e coordenado pela CIMEA;

* Participação da Prefeitura de Suzano como Secretaria Executiva e Apoio na "Il Jornada Internacional de Educação Ambiental", durante a Rio+20 e Cúpula dos Povos, Rio de Janeiro $-\mathrm{RJ}$;

* Encaminhamento do Projeto de Lei da Política e Sistema Municipal de Educação Ambiental ao legislativo:

¿ Desenvolvimento do projeto "Mirambava Sustentável", com ações e atitudes sustentáveis para este importante Complexo formativo Educacional;

* Elaboração, pela CIMEA, do Termo de Referência para a construção do ProMEA-Suzano Programa Municipal de Educação Ambiental, encaminhado ao Órgão Gestor da Política Municipal de Educação Ambiental.

\section{OBSERVAÇÃO :}

Todas as atividades foram realizadas por meio da Cooperação Técnica com o IBECC/UNESCO

(Instituto Brasileiro de Educação, Ciência e Cultura), captação de recursos financeiros junto a Suzano Papel e Celulose e Kimberly-Clark, onde foi possível formar uma equipe durante o período de janeiro de 2010 a março de 2012. 
REALIZAÇÃO:

PREFEITURA MUNICIPAL DE SUZANO

Órgão Gestor da Política Municipal de Educação Ambiental: Secretaria do Meio Ambiente \& Secretaria de Educação Michele de Sá Vieira \& Sonia Kruppa

\section{COORDENAÇÃO:}

* Maria Henriqueta Andrade Raymundo

Coordenadora da Política Municipal de Educação Ambiental - Secretaria do Meio Ambiente

* Luciana Ferreira

Coordenadora da Política Municipal de Educação Ambiental - Secretaria de Educação

\section{COOPERAÇÃO TÉCNICA:}

IBECC/UNESCO Instituto Brasileiro de Educação, Ciência e Cultura (Comissão Estadual de São Paulo) Profa Dra Eda Terezinha de Oliveira Tassara

Prof. Dr. Marcos Sorrentino

EQUIPE TÉCNICA :

* Aline Fernanda dos Santos Guarizo

* Anderson Pagoto

* Maici Miranda Maria da Silva Sech

CIMEA- COMISSÃO INTERINSTITUCIONAL MUNICIPAL DE EDUCAÇÃO AMBIENTAL. Secretaria Executiva da CIMEA (2011-2012):

Secretaria do Meio Ambiente, Secretaria de Educação e Kimberly - Clark

\section{INSTITUICÕES INTEGRANTES DA CIMEA:}

Associação Cultural Suzanense - Bunkio

Titular: Antonia Vidal Prado Gasparotti

Suplente: Minoru Harada

Associação Gusmão dos Santos

Titular: Jair Pedro da Silva

Suplente: André Mendes

Associação das Mulheres do Distrito de Palmeiras de São Paulo

Titular: Noemi Aparecida

Suplente: Rosa Maria Candido

Clariant

Titular: Flavio F. de Almeida

Suplente: Viviane Onofre

Coletivo Educador Voluntários Socioambientais do Alto Tietê Cabeceiras (VoS)

Titular: Aline Fernanda Santos Guarizo

Suplente: Bruna da Silva M. Domingues

Conselho Municipal de Educação

Titular: Miriam Rosires Mendes

Suplente: Edvaldo Alexandre da Silva

SISTEMA E POLITICA MUNICIPAL DE EDUCAÇ̃̃O AMBIENTAL - SUZANO - SP

$$
\text { maio/2009 a novembro/2012 página } 7
$$


Comunidade Kolping São Judas Tadeu

Titular: Gislene Ribeiro dos Santos

Suplente: Adriana Monteiro

Comunidade Kolping São José

Titular: Adriana Monteiro

Suplente: Cristiana A. do Nascimento

Escola Estadual Tokuzu Terazaki

Titular: Nanci Helena Pintan de Oliveira

Suplente: Luciana keiko Niguma

Escola Técnica Estadual - ETEC Suzano

Titular: Fernanda Silva Amorim e Thamires de Campos Luduvice Suplente: Ângelo Ferreira e Victor Dourado Palomares

Fundação MGI

Titular: Priscila Carvalho Bueno

Suplente: Elisangela Melo Campos

Instituição Assistencial e Educacional Espírita "Sal da Terra"

Titular: Maria Aparecida R. Oliveira

Suplente: Ivanete Rosa da Rocha

Instituto de Formação Manoel Neto - Netinho

Titular: Marcio Candido

Suplente: Manoel Lopes

Justiça Eleitoral do Estado de São Paulo - TRE/SP-1819 Suzano-SP

Titular: Imaculada da Conceição Aparecida Pires de Almeida

Suplente: Sandra dos Santos

Kimberly-Clark

Titular: Maria Cecília Jordão e Janaina Karen Rodrigues

Suplente: Jefferson Correia

Komatsu do Brasil

Titular: Mauro Jardim

Suplente: Diego Chaves

Organização Bio-Bras

Titular: Nadja Soares de Moraes

Suplente: Adriana Bravin

Polícia Militar Ambiental do Estado de São Paulo - 12 BPAMB-5a Cia

Titular: Sueli Tavares

Suplente: Washington Nilson Soares

Rede de Educadores Ambientais Populares de Suzano - REAPS

Titular: Fabio Ferreira da Silva

Suplente: Elidiane da Silva Alexandrino

Sanofi - Aventis

Titular: Arnaldo Silva

Suplente: Antonio Tozzati

SISTEMA E POLIITICA MUNICIPAL DE EDUCAÇÃO AMBIENTAL - SUZANO - SP

maio/2009 a novembro/2012 página 8 
Secretaria Municipal de Meio Ambiente

Titular: Maria Henriqueta Andrade Raymundo

Suplente: Michele de Sá Vieira

Secretaria Municipal de Educação

Titular: Maria Laudelina Santos

Suplente: Luciana Ferreira da Silva

Secretaria Municipal de Cultura

Titular: Gilmar Souza Ferreira

Suplente: Ivo Resek

Secretaria Municipal de Defesa Social e Prevenção à Violência

Titular: Antonio Edmilson Alves de Lima

Suplente: Edmundo Gomes da Silva

Secretaria Municipal de Desenvolvimento Econômico, Trabalho, Negócios e Turismo

Titular: Jair Pedrosa

Suplente: Miriam Oliveira Borim

Secretaria Municipal de Esportes, Lazer e Recreação

Titular: Maria Aparecida Monteiro

Suplente: Sérgio Thadeu Paes Miranda

Secretaria Municipal de Governo

Titular: Edson Nogueira Ramos

Suplente: Reinaldo Takashi Katsumata

Secretaria Municipal de Saúde

Titular: Suellen Cristina Idalgo

Suplente: Priscila Jane Arap

Suzano Papel e Celulose

Titular: Vanessa Valente

Suplente: Robson S. Rugai

Suzaquim Ind. Químicas LTDA

Titular: Rita de Cássia Cardoso

Suplente: Joyce Françoso

União dos Escoteiros do Brasil - Grupo Escoteiro Suzano - 37

Titular: José Claudio Schiavi

Suplente: Zilah de Almeida

UNISUZ - Faculdade de Suzano

Titular: Jairo Matozinho Cubas

Suplente: Renato Matsui Pisciotta

Utagua

Titular: José Raimundo Amorim

Suplente: Carlos Alberto da Silva

SUZANO, 12 DE NOVEMBRO DE 2012.

SISTEMA E POLÍTICA MUNICIPAL DE EDUCAÇÃO AMBIENTAL - SUZANO - SP

maio/2009 a novembro/2012 página 9 


\title{
Anexo III - Relatório da Consulta Pública da Lei Municipal de Educação Ambiental
}

\author{
RELATÓRIO DA CONSULTA PÚBLICA DALEI MUNICIPAL DE EDUCAÇAO AMBIENTAL \\ SUZANO-SP
}

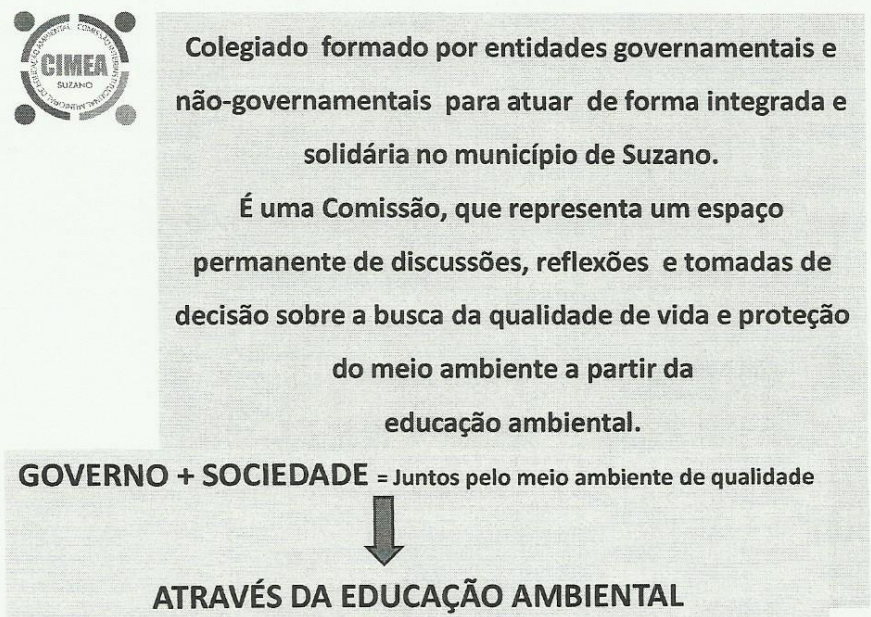

OBjetIVOS DO PROCESSO DE CONSULTA PÚBLICA DA LEI MUNICIPAL DE EDUCAÇÃo AMBIENTAL:

- Informar eenvolver a sociedade na construção da lei de educação ambiental de suzano

\section{DESENVOLVIMENTO DO PROCESSO:}

Foram realizados 4 encontros, nas regiões de Palmeiras, Boa Vista, Centro e Casa Branca, com a apresentação da minuta da Lei Municipal de Educação Ambiental; apresentação de vídeo para sensibilização ambiental, grupos de trabalho e discussão geral da lei e encaminhamentos.A cada Encontro os participantes recebiam a minuta da Lei impressa e eram orientados a se focarem nas 3 questões norteadoas abaixo:

1) O que o grupo entendeu?

2) Qual a relação dessa Lei com a vida de vocês?

3) O Grupo gostaria de apresentar alguma sugestão?

Cada Grupo era orientado também a focar-se num capitulo especifico da Lei Municipal. 
RESULTADOS DO PROCESSO DA CONSULTA PÚBLICA DA MINUTA DA LEI DE EA SUZANO - SP outubro/2011 a fevereiro/2012

ESTRATÉGIAS PARA ACONTECER A CONSULTA:

- 4 ENCONTROS PÚBLICOS NAS REGIÕES DE SUZANO

- CONSULTA ONLINE (SITE E EMAIL)

- REUNIÕES DA CIMEA E CISEA

- REUNIÕES INTERNAS DA PREFEITURA DE SUZANO

- REUNIÕES DA CIMEA COM A CÂMARA DOS VEREADORES

- REUNIÕES DA CIMEA COM ÓRGÃOS AMBIENTAIS E UNIVERSIDADES

PERFIL GERAL DO PÚBLICO ENVOLVIDO NA CONSTRUCÃO

$>$ Professores e alunos da Rede Municipal/Estadual de Ensino

$>$ Educadores Ambientais Populares de Suzano

Técnicos e especialistas em EA

$>$ Gestores Públicos do Município

$>$ Legislativo Municipal

$>$ População e comunidade em geral

TOTAL APROXIMADO DE ENVOLVIDOS $=400$ PESSOAS 


\title{
Anexo IV - Projeto de Lei Complementar
}

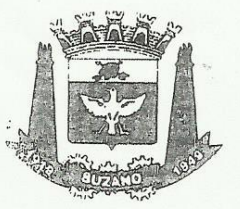

\section{Prefeitura Municipal de Suzano Estado de são paulo}

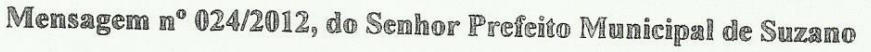 \\ Suzano, 02 de julho de 2012. \\ Senhor $\mathbb{P}$ residente, \\ Nobres Veremdores.
}

Apraz-nos encaminhar o incluso Projêto de Lei Complememign

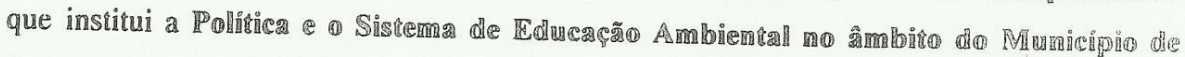

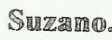

A Constituição Federal incumbe a todos o dever de proteger o meio ambiente como bem ecologicamente sadio para as presentes e futuras gerações, para tanto, todos têm o direito à Educação Ambiental, como parte do processo educativo mais amplo.

A criação e a implantação da Política Municipal de Educação Ambiental e o Sistema Municipal de Educação Ambiental estão em conformidade com os princípios e objetivos de Política Nacional de Educação Ambiental (PNEA), do Programa Nacional de Educação Ambiental (ProNEA) e da Políica Estadual do Meio Ambiente, e deverão articular-se com os sistemas de meio ambiente e educação em ámbito federal, estadual e municipal.

A minuta de Lei Complementar proposta, institui a Política e o Sistema Municipal de Educação Ambiental de Suzano, em consonância com a Política Nacional de Educação Ambiental Lei no 9795 de 27 de abril de 1999; Política Estadual de Educação Ambiepral, Lei $\mathfrak{n}^{\circ} 12.780$ de 30 de novembro de 2007 e a Lei Municipal de Meio Ambiente Lei $\mathrm{n}^{\circ} 13 \mathrm{~s}$ de 19 de dezembro de 2003.

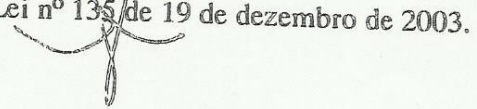




\section{Prefeitura Municipal de Suzano Estado de são Paulo}

Portanto, é com grande satisfação que encaminhamos para as

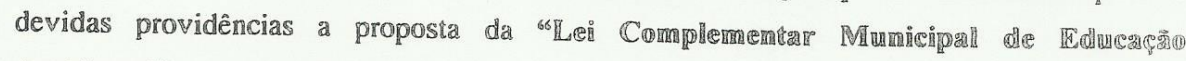
Ambiemtal", construída democraricamente com participação popular, reflexão aprendizagem socioambiental.

Diante do exposto, espero favorável acolhida por parte dessa Colenda Câmara para a proposição da Lei Complementar mencionada, em Reginne de

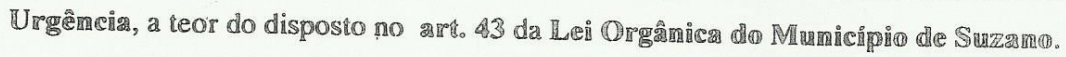

No aguardo de um pronunciamento favorável, aproveitamos o ensejo para renovar os nossos protestos de elevada ostima e admiração.

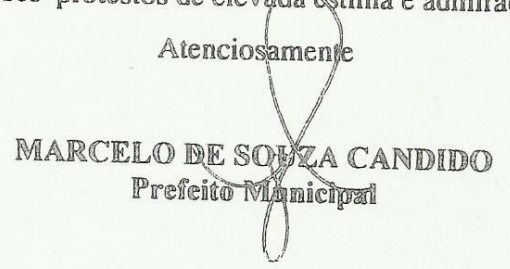

Excelentissimo Senhor

JOSE IZAQUEU RANGEL

DD. Presidente da Câmara Municipal de Suzano 


\section{Prefeltura Municipal de Suzano Estado de são paulo}

\section{PROJETO OE LEI CONPLEMENTAR NO}

Instirui a Política e o Sistema Municipal de Educação Ambiental de Suzamo, e dá outras providências.

legais que lhe são conferidas;

O PRETETO MUNICIPAL, DE SUZANO, usando das atribuiçöes
feridas; a seguinte Lei Complementar:

FAZ SABER que a Câmara Municipal de Suzano aprova e ele promulga
plementar:

\section{CAPITULOI}

Art. 10. Entende-se por Educação Ambiental os processos continuos e permanentes de para a formaçäo individual oniveis e modalidades de ensino, em caráter escolar e não escolar, conhecimentos, habilidades, coletiva, reflexão e ação crítica e construção de valores, saberes, socioambiental para a melhoria da competências visando o deservolvimento da cidadania sustentável da sociedade com a qualidade da vida de todos e a construção de uma relaçäo

Art. $2^{\circ}$. A educação ambiental, direito de todos, é um componente essencial e permarente da educaçāo e gestão ambiental, đevendo estar presente no âmbito municipal de forma articulada em todos os níveis e modalidades do processo educativo, em caráter escolar e não escolar.

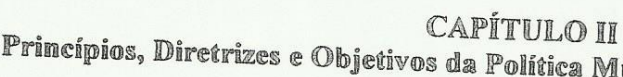

Arto $3^{\circ}$. Os princípios básicos da Educação Ambiental são:

II- o enfoque humanístico, sistêmico, democrático e participativo;

II- a concepção do meio ambiente em sua totalidade, considerand entre o meio natural, sustentabilidade; - pluralismo de idéias e concepções pedagógicas, na perspectiva da

IV- $\quad$ a vincultidisção entre a ética, arisciplinaridade e transdisciplinaridade;

as práticas socioambientais. as práticas socioambientais

a garantia de continuidade, permanência e articulação do processo educativo com
todos os indívíduos e grupos sociais;

VI- a permanents avaligasos sociais;

VII- a abordagem avalidção crítica do processo educativo;

global;

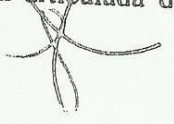




\section{Prefeitura Municipal de Suzano Estado de são Paulo}

\footnotetext{
VIIIIO respeito e valorização da pluralidade, da diversidade cultural e do conhecimento
e práticas tradicionais;

HX- $\quad 2$ promoção da eqüidade social e econômica:

X- a promoção do exercício permanente do diálogo, da alteridade, da solidariedade, da co-responsabilidade e da cooperação entre todos os setores sociais;

XIestimular a refle
}

Art. 40. Os objetivos fundamentais da Educação Ambiental no Municipio de Suzano são:

I.

III-

a construção de uma sociedade ecologicamente responsável, economicamente viável, culturalmente diversa, politicamente atuante e socialmente justa:

- desenvolvimento de uma compreensão integrada do meio ambiente em suas psicológicos, legais, políticos, envolvendo aspectos ecológicos, históricos, tecnológicos e éticos;

棋具-

IV. $\quad$ a garantia da democratização e a socialização das informações socioambientais: fortalecendo o exercício da cidadania discussão das questöes sociombientais critica e ética; $\quad$

V. promover o conhecimento e a formação de educadores ambientais populares ou de agentes multiplicadores em educação ambiental, abrangendo os espaços escolares - incentivo à participação comunithio a reflexão e ação críticas e éticas: proteção, preservação e conservacão do ativa, permanente e responsável rid se a defesa da qualidade ambiental do equilíbrio do meio ambiente, entendendocidadania;

VIII incentivar a formação de educadores ambientais populares e também de gruroos voltados para as questões socioambientais edus populares e também de grupos sociais e privadas;

VIII- fortalecimento da integração entre ciência e tecnologia, em especial o estímulo à adoção de práticas sustentáveis que minimizem os impactos negativos sobre

IXo fortalecimento da cidadania, autodeterminacão viáveis, justas e solidárias; fundamemtos para o futuro da humanidade. - desenvolvimento de programasidade;

integrados 20 zoneamento ambras, projetos e ações de educação ambiental dos resíduos sólidos e do saneamentoturismo, mudanças climáticas, à gestão recursos hídricos, e uso do solo, do ambiental, à gestão da qualidade dos administração das unidades de conservaçã a manejo dos recursos florestais, à ao uso e ocupação do solo, à preparaçąa e das áreas especialmente protegidas, em áreas de risco tecnológico, desenvolvimento urbano, ao planejamento geológico e risco hidrológico, ao das atividades agrícolas e das atividades industonsportes, ao desenvolvimento tecnologias, ao chnsumo e à defesa do patrimóniostriais, ao desenvolvimento de

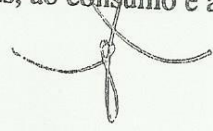




\section{Prefeitura Municipal de Suzano Estado de são Paulo}

XI- O estímulo à criação, o fortalecimento e ampliação, promovendo a comunicação e cooperação em nivel locall e regional das:

a.-) redes de Educação Ambiental;

b.-) núcleos de Educação Ambiental;

c.-) coletivos jovens de meio ambiente;

d.-) coletivos educadores e outros coletivos organizados;

e.-) comissōes;

$\left.\mathbb{f}_{0}-\right)$ fóruns;

g.-) colegiados;

h.-) câmaras técnicas.

XII- a busca da descentralização espacial e institucional na construção e implementação da Política e do Programa Municipal de Educação Ambiental.

\section{CAPITULO III

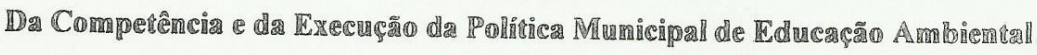

Art. $5^{๑}$. No âmbito da Política Municipal estabelecida por esta Lei Complementar compete ao Poder Público promover:

1.

a incorporação da dimensão socioambiental e dos conceitos de ecodesenvolvimento e sociedades sustentáveis no planejamento e execução das políticas públicas municipais;

III- a educação ambiental em todos os níveis de ensino;

H耳耳- a mobilização, formação e sensibilização da população quanto à importância da valorização do meio ambiente, da paisagem e recursos naıurais e arquitetônicos da cidade, com especial foco nas lideranças locais e em editores e multiplicadores;

IV - engajamento da sociedade na conservação, recuperação, uso e melhoria do meio ambiente, inclusive com utilização de meios de difusão em massa e processos de formação em comunicação comunitária;

V. a formação e a transversalidade no ambito interno do poder público local, garantindo a universalização e prática dos princípios da sustentabilidade socioambiental no exercício das atividades públicas;

VII meios de integraçäo das açöes em prol da educação ambiental realizadas pelo

VIIpoder público, pela sociedade civil organizada e pelo setor empresarial;

Art. 6. A Política Municipal de Educação Ambiental envolve em sua esfera de ação, instituições educacionais públicas e privadas dos sistemas de ensino, órgãos públicos do município, organizações não governamentais, CIMEA-Comissão Interinstitucional Municipal de Educação Ambiental, CISEA-Comissão Intersetorial de Educaça Ambiental e demais instituições e organizaçōes, comp Redes de educação ambiental, Núcleos de educação ambiental, ComVidas (Comispóes fe Meio ambiente e Qualidade de Vida) nas escolas e Fóruns coletivos jovens de meit ampiente e outros coletivos organizados. 


\title{
Prefeitura Municipal de Suzano Estado de são Paulo
}

\author{
CAPITULO IV

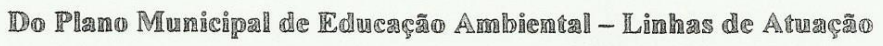

Art. 7\%. Na determinação das ações, projetos e programas vinculados à Policica Municipal de Educação Ambiental, devem ser privilegiadas as medidas que comportem:

I- $\quad$ formação para o desenvolvimento das capacidades humanas;

III- desenvolvimento de estudos, pesquisas e experimentações;

III- produção participativa de material educativo e sua ampla divulgação; e

IV- acompanhamento e avaliação processual.

Ars. $\mathbb{B}^{\circ}$. A formaça para o desenvolvimento das capacidades humanas, voltada para as modallidades escolar e não escolar, comporta as seguintes dimensões:

l- a incorporação da dimensão socioambiental durante a formação, as especialização e atualização dos educadores de todos os niveis e modalidades de ensino;

Il- a formação e atualização de profissionais especializados na área de meio ambiente. bem como, de profissionais de outras áreas de atuação;

III- o atendimento da demanda dos diversos segmentos da sociedade para a formacão em educação ambiental.

Art. 9:. As ações de estudos, pesquisas e experimentações voltar-se-ão para:

1- o desenvolvimento de instrumentos e metodologias visando æ̀ incorporação da dimensão socioambiental, de forma transversal e interdisciplinar, nos diferentes níveis e modalidades de ensino-aprendizagem;

II- a construção de conhecimentos e difusão de informaçöes sobre a questão socioambiental;

IIL- o desenvolvimento de instrumentos e merodologias visando à participação das populações interessadas na formulação e execução de pesquisas relacionadas à problemática socioambiental;

IV- a busca de alternativas curriculares e metodológicas de formacão na área socioambiental;

V- $\quad$ apoio a iniciativas e experiências locais e regionais:

VI- a identificação dos problemas e possibilidades de construção coletiva de alternativas para sociedades sustentáveis.

Art. 10. Na produção de material educativo deverá ser observada a identificação de sen público-alvo, com vistas à determinação da linguagem e mensagem apropriadas, bem como a exposição e a vallorização do patrimônio ambiental do município de Suzano.

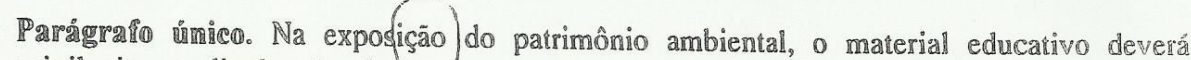
privilegiar a divulgação de majcos ambientais, assim compreendido os bens naturais considerados identificadores da eidade. 


\section{Prefeitura Municipal de Suzano Estado de são paulo

\author{
STCCÃOI

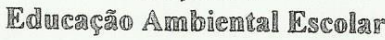

Arê. 11. Entende-se por educação ambiental escolar as desenvolvidas no âmbito dos currículos das instituições escolares públicas e privadas, englobando:

I- Educação infíantil e fundamental;

Pl- $\quad$ Educação média e tecnológica;

HIII- Educação especial;

IV- $\quad$ Educação para populações tradicionais ;

V. $\quad$ Educação de jovens e adultos - EJA.

Art. 12. A educação ambiental será desenvolvida como uma prática educativa integrada, transversal, contínua e permanente inserida no Projeto Político Pedagógico das escolas em todos os níveis e modalidades de ensino formal.

\$1․ A educação ambiental não será implantada como disciplina específica no currículo escolar da rede pública municipal, salvo em atividades de extensão, de caráter complementar e extracurricular.

\$2०. Nos cursos de formação e especialização técnico-profissional, em todos os níveis, deve ser incorporado conteúdo que trate da ética socioambiental ambiental das atividades profissionais a serem desenvolvidas.

Arto 13. A dimensão socioambiental deve constar dos currícullos de formação continuada de professores, em todos os níveis e em todas as disciplinas.

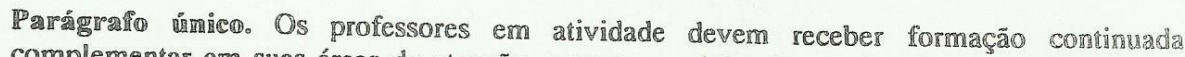
complementar em suas áreas de atuação, com o propósiro de atenderem adequadamente ao cumprimento dos princípios e objetivos da Política Municipal de Educação Ambiental.

\section{SECCÃO H耳

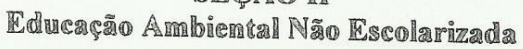

Art. 14. Entende-se por educação ambiental não escolarizada as ações e práticas educativas voltadas à mobilização, sensíbilização e formação da coletividade sobre a temática socioambiental, e à sua organização e participação na defesa da qualidade do meio ambiente e busca de relações sustentáveis entre sociedade e natureza, buscando a melhoria na qualidade
de vida de todos e todas.

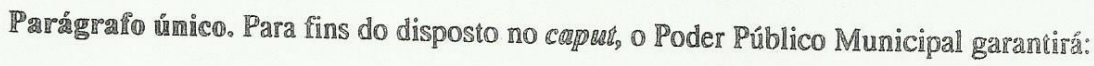

1. a difusão, por intermédio dos meios de comunicação de massa, de programas

11. aducativos e de informações acerca de temas relacionados ao meio ambiente: a ampla participaçã das escolas, das universidades e de organizaçöes não governamentais na formulação e execução de programas e atividades vinculadas à educação ambiental nąp e colarizada;

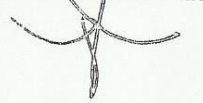




\section{Prefeitura Municipal de Suzano Estado de são Paulo}

III. a participação de empresas públicas e privadas no desenvolvimento de programas de educação ambiental em parceria com as escolas e organizações nãogovernamentais;

IV. a sensibilização da sociedade para a importância dos instrumentos e unidades de gestäo ambientall, bem como, a formação de educadores ambientais populares;

V. a mobilização, sensibilização e formação em educação ambiental dos grupos participantes de movimentos sociais e ambientalistas.

\section{SEC \\ Das Cominssẽes}

Art. 15. A Secretaria Municipal de Meio Ambiente e a Secretaria Municipal de Educação assumem a funçà̃o de Orgão Gestor da Política Municipal de Educação Ambiental, de caráter deliberativo com apoio e assessoramento da CISEA (Comissäo Intersetorial de Educação Ambiental) e CIMEA (Comissão Interinstitucional Muñicipal de Educação Ambiental).

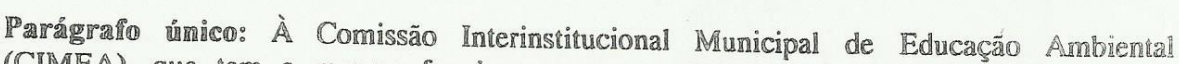
(CIMEA), que tem o mesmo funcionamento e atribuição de um Conselho Municipal,

耳-

O dimensionamento de recursos, junto ao Órgão Gestor dessa Política Municipal, II- $\quad$ para fim de subsidiar os projetos de leis orçamentárias;

desenvolver processos de autoformação continuada dos seus membros, no campo
da educação ambiental;

IIIdesenvolvidos pela Prefeicura programas de educação ambiental no Município, planejamento territorial sustentável, pela sociedade civil, e contribuir para o

IV. $\quad$ Promover articulacōes sustentável, participativo e educador; Promover articulaçōes intrainstítucionais e interinstitucionais objecivando
implementar a Política Municipal de Educação Ambiental;

V- Assessorar o órgão gestor na promoção de uma conferência anual de avaliaça da política municipal de educação ambiental, com a presença de representantes do setor público, da sociedade civil e das empresas que desenvolvam iniciativas de
educação ambiental.

\section{CAPITUULO Y \\ Do Sistera Mumicipal de Educaşa Ambiental}

Art.16. O Sistema Municipal de Educação Ambiental (SISMEA) compreende:

I-

Orgão Gestor da Política Municipal de Educação Ambiental formado pela
Secretaria Municipal de Meio Ambiente a função de:

2) Coordenar, artiectar, propor diretrizes para a implementacão e superyisionar a Política e o Sistema Municipal de Educação Ambiental, incentivando a capilaridade da Educação Ambiental, conforme sua competências
regulamentar; 


\section{Prefeitura Municipal de Suzano Estado de são Paulo}

b) Coordenar a construção participativa e a implementação de um Progra. Municipal de Educação Ambiental, garantindo a sua avaliação e revisão forma democrática e periódica;

e) Participar do financiamento de programas, planos e projetos de Educaç Ambiental, conforme regulamento e previsão orçamentária própria.

HIL CISEA - Comissão Intersetorial de Educação Ambiental, formada representantes titular e suplente de cada secretaria e vinculadas da Prefeitu Municipal; com a funçāo de fazer a política interna de educaçäo ambient articulada e integrada, implementando a Agenda Ambiental da Administraç Pública (A3IP), a sensibilização e a formaça continuada dos colaborador funcionários e servidores públicos da Prefeitura Municipal de Suzano;

III. CIMEA - Comissão Interinstitucional Municipal de Educação Ambiemi collegiado gestor de caráter permanente, democrático e deliberativo é forma paritariamente por representantes dos segmentos da sociedade civill organizada poder público, com a função de acompanhar, participar, apoiar, fortalecer e avali a política e programa municipal de educação ambiental, sendo regulamentada e decreto municipal a partir de regimento interno.

IV- COM-Vidas - Comissão de Meio Ambiente e Qualidade de Vida, são comisso cuja função é comtribuir na construção de programas de educação ambien inseridos no Projeto Político Pedagógico das unidades escolares, organizadas e polos regionais, constituídas por estudantes e pela comunidade interna e exter. das escolas da Rede Municipal de Ensino. As Com-Vidas devem reunirperiodicamente com os Conselhos de Escola para, conjuntamente, acompanhí apoiar, fortalecer e avaliar continua e permanentemente os programas e projet da Educação Ambiental Escolar.

$\mathbb{V}$

Rede de Educadores Ambientais Populares de Suzano (REAPS) formada a par do Programa Municipal de Educação Ambiental Popular, com incentivo fortalecimento de outros Coletivos Educadores e Redes Educador: Socioambientais instituidas e reconhecidas oficialmente no município e região.

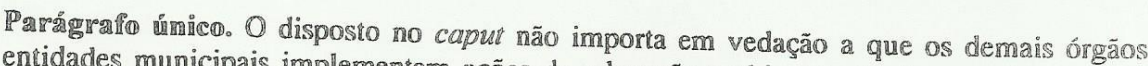
entidades municipais implementem ações de educação ambiental, desde que observados Ambiental.

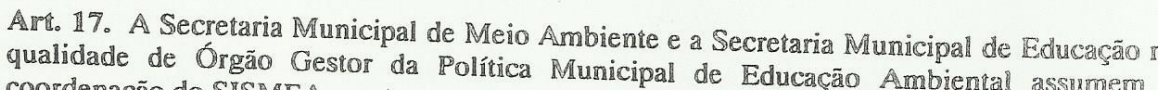
coordenação do SISMEA que tem a competêneia de:

I- definir diretrizes e elaborar, de forma participativa, o Programa Municipal Educação Ambiental;

目些definir diretrizes dos programas e projetos, no âmbito da política municipal d educação ambiental, bem como articular, coordenar, executar, supervisionar monitorar a implantação de suas açōes;

具Iparticipar na negociação de financiamentos a programas e projetos na área d
eđucação ambiental;

IVacompanhar e avaliar, pormanentemente, a Política e o Programa Municipal d
Educação Ambiental;

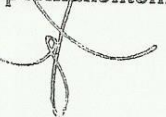




\section{Prefeitura Municipal de Suzano Estado de São Paulo}

V- articular junto ao governo federal e estadual, na implementação e monitoramento das Políticas, programas e projetos no âmbito municipal, contribuindo para a existência do Sistema Nacional de Educação Ambiental.

Arr. 18. A implementação de planos, programas e projetos de educação ambiental escolar devem ser submetidos a Secretaria Municipal da Educação e ao Conselho Municipal de Educação, observada a legislação em vigor.

Art. 19. Para efeiros desta Política, e sem prejuízo do reconhecimento de novas metodologias e práticas, a Educação Ambiental deve ser fortalecedora dos processos participativos e parte integrante dos seguintes processos gestão ambiental:

I- Recursos Hídricos;

II- Biodiversidade;

IIL- Unidades de Conservação;

IV. Zoneamento Ecológico-Econômico;

V. Licenciamento Ambiental;

VI- Resíduos Sólidos, Saneamento Ambiental e Controle de Zoonoses;

VII- $\quad$ Florestal;

VIII- Paurimônio Ambiental Cultural;

IX- Controle da Qualidade do Ar;

X- Turismo Sustentável;

XI- Desenvolvimento Territorial Sustentável ;

XII- Prevenção, Adaptação e mitigação das mudanças climáticas.

\section{CAPITULO VI}

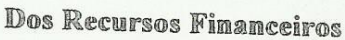

Arê. 20. A Secretaria Municipal de Meio Ambiente, a Secretaria Municipal da Educação e os demais órgãos do Município de Suzano, deverão consignar em seus orçamentos recursos necessários ao desenvolvimento de programas, projetos e açóes de educação ambiental, Política e Sistem plano plurianual orçamento direcionado a contemplar a efetivaçāo desta Política e Sistema Municipal de Educação Ambiental.

Arêt. 21. Fica instituído o Fundo Murgicipal de Educação Ambiental (FMEA) a partir da publicação desta Lei Complementpr corn recursos provenienies de outros fundos municipal, estadual, federal ou privados, além de outras fontes possíveis. 


\section{Prefeitura Municipal de Suzano Estado de são paulo}

Arr. 22. A seleça de projetos, planos e programas para alocação de recursos do Fundo Municipal de Educação Ambiental deve ser realizada pela CIMEA em conjunto com o Órgão Gestor da política Municipal de Educação Ambiental, levando-se em conta os seguintes critérios:

I- conformidade com princípios, objetivos e diretrizes da Política Municipal de Educação Ambiental;

Il- economicidade, medida pela relação e magnitude dos recursos a allocar e o retorno

IIIsocioambiental, utilizando-se indicadores qualitativos e quantitativos;

análise da sustentabilidade dos planos, programas e projetos em Educação Ambiental que deverá contemplar a capacidade institucional e a continuidade dos planos, programas e projetos.

\section{CAIPITULO VII \\ Das Disposięẽes Thima:}

Art. 23. Fica instituído o "Calendário Socioambiental Anual" para atividades de formação, mobilização sociall, sensibilização, construção e produção de conhecimentos socioambientais no Município de Suzano em celebração ao dia do "Educador Ambienial Popular", na data de 03 de fevereiro; "Semana da Água" com a data base de 22 de março; "Semana do Meio Ambiente" data base de 05 de junho; "Semama da Comunicapão", data base 07 de julho; "Semana da Agricultura Orgânica" com data base no dia 21 de setembro, juntamente com o "Dia da Árvore"; "dia do Rio Tiete" 22 de setembro, fortalecendo as açōes e reflexões pela sustentabilidade socioambiental.

Art. 24. Criam-se os Centros de Educação Ambiental (CEAS) com o objetivo da constituieção de referências em educação ambiental na Região do Alto Tietê Cabeceiras, com orçamentảrio público ou privado, a partir dos parâmetros e diretrizes estabelecidas pelo MMA (Ministério do Meio Ambiente) e integração a Rede Brasileira de Centros de Educação Ambiental- (RedeCEAs) e enr consonância com o Plano Municipal de Educação.

Art. 25. Esta Lei Complementar entra em vigor na data de sua publicação. Paço Municipal "Prefeito Firmino José da Costa, 02 de julho de $2012,63^{\circ}$ da Emancipação
Político-Administrativa. 